\title{
CARACTERIZAÇÃO BIOLÓGICA, SEROLÓGICA E MOLECULAR DE UMA ESTIRPE DO PASSION FRUIT WOODINESS VIRUS (PWV) QUE INFECTA SISTEMICAMENTE ALGUMAS CUCURBITÁCEAS
}

\section{RICARDO GIORIA}

\footnotetext{
Tese apresentada à Escola Superior de Agricultura "Luiz de Queiroz", Universidade de São Paulo para obtenção do título de Doutor em Agronomia, Área de Concentração: Fitopatologia.
}

PIRACICABA

Estado de São Paulo - Brasil julho - 2003 


\section{CARACTERIZAÇÃO BIOLÓGICA, SEROLÓGICA E MOLECULAR DE UMA ESTIRPE DO PASSION FRUIT WOODINESS VIRUS (PWV) QUE INFECTA SISTEMICAMENTE ALGUMAS CUCURBITÁCEAS}

\section{RICARDO GIORIA}

Engenheiro Agrônomo

Orientador: Prof. Dr. JORGE ALBERTO MARQUES REZENDE

Tese apresentada à Escola Superior de Agricultura "Luiz de Queiroz", Universidade de São Paulo para obtenção do título de Doutor em Agronomia, Área de Concentração: Fitopatologia.

PIRACICABA

Estado de São Paulo - Brasil

Julho - 2003 
Dados Internacionais de Catalogação na Publicação (CIP) DIVISÃO DE BIBLIOTECA E DOCUMENTAÇÃO - ESALQ/ USP

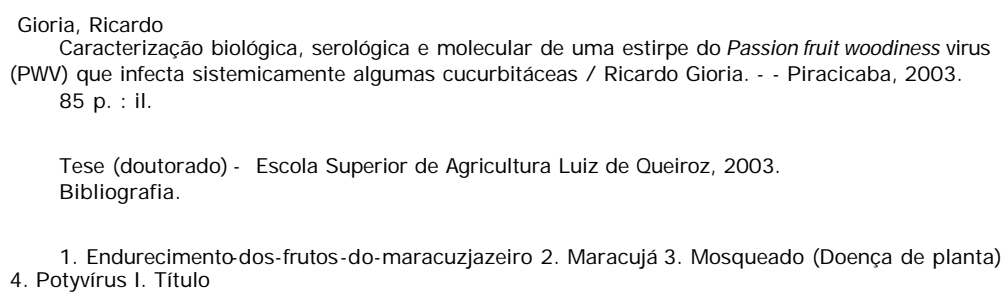

CDD 634.425

"Permitida a cópia total ou parcial deste documento, desde que citada a fonte - O autor" 
A meus pais, Eloy e Olene, meu irmão Claudio e esposa Luciani, minha esposa Vanessa e filha Estela, pelo apoio paciência e compreensão, com amor, DEDICO 


\section{AGRADECIMENTOS}

À Deus, pela constante presença em nossas vidas e pela graça de mais uma etapa alcançada;

Ao Prof. Dr. Jorge A. M. Rezende, pela orientação desta tese, pelo incentivo, confiança, paciência, amizade e pela grande contribuição na minha formação como pesquisador;

Ao Prof. Dr. Elliot W. Kitajima, pelas fotos utilizadas neste trabalho e pelo auxílio nos trabalhos desenvolvidos no núcleo de microscopia de ESALQ/ USP;

Ao Prof. Dr. Luis Eduardo Aranha Camargo, pela concessão de uso do Laboratório de Genética Molecular do Setor de Fitopatologia da ESALQ/ USP;

Ao técnico do Laboratório de Virologia Vegetal do Setor de Fitopatologia da ESALQ/ USP, José Edivaldo Buriolla;

Ao Sr. Pedro C. Arthuso, pelo auxílio na manutenção dos trabalhos desenvolvidos em casa-de-vegetação do Setor de Fitopatologia da ESALQ/ USP;

À Fundação de Amparo à Pesquisa do Estado de São Paulo (FAPESP), pela concessão de bolsa de estudos durante o curso de Doutorado;

Aos professores e funcionários do Setor de Fitopatologia da ESALQ/ USP pelos conhecimentos transmitidos, pela amizade e contribuição na obtenção deste título;

Aos colegas do curso de Pós-graduação em Fitopatologia, por todo apoio durante a realização dos estudos, em especial aos colegas do Laboratório de Virologia Vegetal: Davi Pacheco, José Giampan, Juliana Freitas- 
Astua, Louise Mota, Luiz Rabelo, Marília Della Vecchia, Paulo Oliveira, Quelmo Novaes, Zayame Pinto;

À SAKATA Seed Sudamerica LTDA pelo apoio na finalização desta tese;

À todos aqueles que direta ou indiretamente contribuíram para a realização deste trabalho;

Finalmente, agradeço àminha família em especial a meus pais, irmão e esposa, por toda paciência, incentivo, compreensão e amor. 


\section{SUMÁRIO}

Página

LISTA DE FIGURAS .............................................................................. ix

LISTA DE TABELAS ................................................................................ x

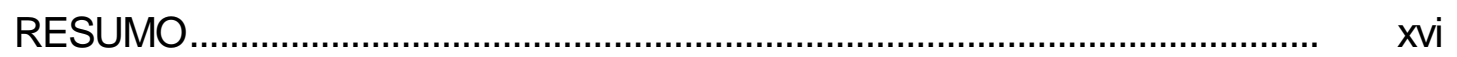

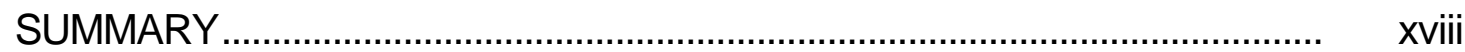

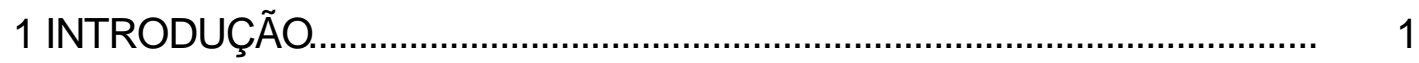

2 REVISÃO DE LITERATURA ................................................................. 3

3 MATERIAL E MÉTODOS .................................................................... 12

3.1 Plantas-teste ......................................................................................... 12

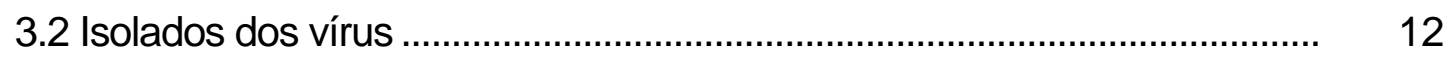

3.3 Inoculação mecânica............................................................................... 13

3.4 Gama de hospedeiras ......................................................................... 13

3.5 Microscopia eletrônica......................................................................... 14

3.6 Purificação do potyvírus causador de mosqueado em maracujazeiro .... 15

3.7 Produção de antissoro........................................................................... 16

3.8 Testes de transmissão.............................................................................. 17

3.8.1 Efeito da espécie fonte de inóculo na eficiência da transmissão

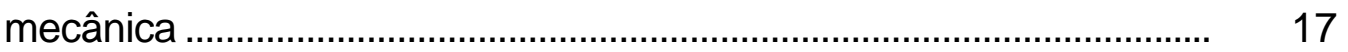

3.8.2 Efeito da espécie fonte de inóculo na eficiência de transmissão por afídeos..................................................................................... 17

3.8.3 Efeito da idade das folhas de abobrinha-de-moita na aquisição e transmissão por afídeos ............................................................................. 18

3.9 Determinação do peso molecular da proteína da capa protéica ............. 19 
3.10 Isolamento do RNA viral, quantificação e determinação do peso molecular.

3.11 Relacionamento serológico

3.12 PTA-ELISA

3.13 Teste de proteção entre isolados do potyvirus causador de mosqueado e do PWV.

3.14 Efeito do potyvírus causador do mosqueado no desenvolvimento das plantas de maracujazeiro em casa-de-vegetação.

3.15 Caracterização molecular do gene da capa protéica do potyvírus causador do mosqueado em maracujazeiro.

3.15.1 Extração de RNA total 26

3.15.2 RT-PCR 26

3.15.3 Ligação ao plasmídeo vetor 28

3.15.4 Preparo de células competentes de Escherichia coli para transformação.

3.15.5 Transformação de E. coli com plasmídeo vetor recombinante.......... 29

3.15.6 Extração de DNA plasmidial.............................................................. 30

3.15.7 Sequenciamento ............................................................................ 32

3.16 Análise dos resultados......................................................................... 33

4 RESULTADOS .......................................................................................... 34

4.1 Microscopia eletrônica........................................................................... 34

4.2 Purificação do potyvírus causador de mosqueado em maracujazeiro e produção de antissoro.

4.3 Gama de hospedeiras do potyvírus causador de mosqueado em maracujazeiro

4.4 Transmissão do potivírus do mosqueado.

4.4.1 Efeito da espécie fonte de inóculo na eficiência da transmissão mecânica

4.4.2 Efeito da espécie fonte de inóculo na eficiência da transmissão por afídeos. 
4.5 Peso molecular da proteína da capa protéica e do RNA viral ................. 46

4.6 Relacionamento serológico com outros potyvirus ..................................... 46

4.7 Proteção entre isolados do potyvírus causador de mosqueado em maracujazeiro e do PWV

4.8 Efeito do potyvírus causador de mosqueado no desenvolvimento das plantas de maracujazeiro em casa-de-vegetação.

4.9 Seqüências de nucleotídeos e de aminoácidos deduzidos do gene da capa protéica do potyvírus causador de mosqueado em maracujazeiro

5 DISCUSSÃO 66

6 CONCLUSÕES. 74 


\section{LISTA DE FIGURAS}

Página

1 Sintoma de mosqueado em planta de maracujazeiro amarelo

2 Micrografia eletrônica de 'leaf dip', exibindo partículas virais alongadas, típicas do gênero Potyvirus, encontradas em amostras de plantas de abobrinha-de-moita 'Caserta' inoculadas com extratos de plantas de maracujazeiro apresentando sintomas de mosqueado foliar

3 Sintoma de amarelecimento de nervuras apresentado por planta de abobrinha-de-moita 'Caserta' inoculada com extrato foliar de planta de maracujazeiro exibindo sintoma de mosqueado.

4 Representação esquemática do genoma do gênero Potyvirus, enfatizando a localização da região de anelamento dos primers PV1 e PV2. $(A)_{n}$, cauda poli-A; NT, terminal 3' não traduzido; CP, capa protéica; Nib, inclusão nuclear b.

5 Micrografia eletrônica de secção de folha de abobrinha-de-moita cv. Caserta, infectada com o potyvírus do mosqueado e exibindo sintomas de amarelecimento de nervuras, aonde podem ser observas inclusões do tipo cata-vento, típicas de vírus do gênero Potyvirus. 
6 Observação, em microscopia eletrônica de transmissão, do purificado do potyvírus causador de mosqueado em maracujazeiro

7 Teste de 'Western blot' utilizando antissoro produzido contra o potyvírus causador de mosqueado. (M) marcador de peso molecular; (1) purificado do potyvírus do mosqueado; (2) extrato de maracujazeiro infectado com o potyvírus do mosqueado; (3) extrato de 'Caserta' infectada com o potyvírus do mosqueado; (4) 'Caserta' sadia e (5) maracujazeiro sadio.

8 RNA isolado de um purificado do potyvírus causador de mosqueado em maracujazeiro. (M) marcador de peso molecular; (1) RNA do potyvírus do mosqueado.

9 Teste de 'Western blot' utilizando antissoro contra o potyvírus causador de mosqueado (A) e contra o PWV (B). (M) marcador de peso molecular; (1) extrato de maracujazeiro infectado com o potyvírus do mosqueado; (2) extrato de maracujazeiro infectado com o PWV; (3) extrato de maracujazeiro sadio

10 Altura média de plantas sadias (S), infectadas com três isolados do potyvírus causador de mosqueado em maracujazeiro (M1, M2 e M3) e com dois isolados do PWV (PWV-1 e PWV-2), em casa-devegetação. Barras com letras distintas, dentro de cada experimento, diferem entre si ao nível de $5 \%$ pelo teste de Tukey 
11 Área foliar média de plantas sadias (S), infectadas com três isolados do potyvírus causador de mosqueado em maracujazeiro (M1, M2 e M3) e com dois isolados do PWV (PWV-1 e PWV-2), em casa-devegetação. Barras com letras distintas, dentro de cada experimento, diferem entre si ao nível de $5 \%$ pelo teste de Tukey.

12 Fragmentos amplificados por RT-PCR, observados em gel de agarose $1 \%$, corado com brometo de etídeo. $\mathrm{M}$, marcador de peso molecular (1kb DNA Ladder); 1, amostra sadia; 2 e 3, fragmentos de aproximadamente 1.700 pares de bases dos isolados M2 e M3 do vírus causador de mosqueado em maracujazeiro, respectivamente.

13 Dendrograma construído com base na seqüência completa de nucleotídeos do gene da capa protéica dos isolados do potyvirus causador do mosqueado em maracujazeiro e outros potyvirus. A árvore foi gerada com o programa MEGA. As porcentagens de "bootstrap" com 2000 repetições são indicadas nos braços da árvore

14 Alinhamento das seqüências de nucleotídeos do gene da capa protéica dos isolados M2 e M3 do potyvírus causador de mosqueado em maracujazeiro e de duas estirpes do PWV (PWV F101 e PWV-SP).

15 Alinhamento das seqüências de nucleotídeos da região 3' não traduzida dos isolados M2 e M3 do potyvírus causador de mosqueado em maracujazeiro e de duas estirpes do PWV (PWV F101 e PWV-SP). 
16 Alinhamento das seqüências de aminoácidos deduzidos do gene da capa protéica dos isolados M2 e M3 do potyvírus causador de mosqueado em maracujazeiro e de duas estirpes do PWV (PWV F101 e PWV-SP). 


\section{LISTA DE TABELAS}

Página

1 Valores de absorbância $\left(A_{450}\right)$ em teste de PTA-ELISA utilizando 4 diluições do antissoro* contra o potyvírus do mosqueado e 5 diluições de extrato foliar de maracujazeiro amarelo $(P$. edulis $\mathrm{f}$, flavicarpa) sadio e infectado.

2 Reação de diferentes espécies vegetais inoculadas mecanicamente com três isolados do potyvírus causador de mosqueado em maracujazeiro (M1, M2 e M3) e com dois isolados do PWV (PWV-1 e PWV-2)

3 Eficiência de transmissão mecânica do potyvírus causador de mosqueado em maracujazeiro, isolado M1, para abobrinha-demoita cv. Caserta, maracujazeiro amarelo, feijão preto cv. BT-2 e Crotalaria juncea utilizando plantas infectadas de 'Caserta', maracujazeiro amarelo, feijão preto cv. BT-2 e C. juncea como fontes de inóculo 
4 Eficiência de Myzus persicae (MP) e Aphis gossypii (AG) na transmissão do potyvírus causador de mosqueado em maracujazeiro, isolado M1, para abobrinha-de-moita cv. Caserta, maracujazeiro amarelo, feijão preto cv. BT-2 e Crotalaria juncea, utilizando folhas do ponteiro de 'Caserta', maracujazeiro amarelo, feijão preto cv. BT-2 e C. juncea infectadas como fontes de inóculo......

5 Eficiência de Myzus persicae e Aphis gossypii na transmissão do potyvírus causador de mosqueado em maracujazeiro, isolado M1, para abobrinha-de-moita cv. Caserta e maracujazeiro amarelo, adquirido em folhas de 'Caserta' em 3 estádios de desenvolvimento (início de desenvolvimento- ID, parcialmente expandida- PE e folha madura- FM).

6 Valores de absorbância $\left(\mathrm{A}_{450}\right)$, obtidos em teste de PTA-ELISA utilizando antissoros diluídos 1:1000, contra a proteína da capa protéica do potyvírus do mosqueado, do PWV, do ZYMV e do PRSV-W.

7 Experimentos de proteção entre os isolados PWV-1 e PWV-2 e os isolados M1, M2 e M3 do potyvírus causador de mosqueado em maracujazeiro, em plantas de Passiflora edulis f. flavicarpa e Crotalaria juncea, avaliado através da recuperação dos isolados desafiantes em plantas de abobrinha-de-moita cv. Caserta. 
8 Peso fresco da parte aérea, do sistema radicular e total, de plantas de maracujazeiro sadias, infectadas com três isolados do potyvírus causador de mosqueado em maracujazeiro (M1, M2 e M3) e com dois isolados do PWV (PWV-1 e PWV-2), em dois experimentos distintos, realizados em casa-de-vegetação.

9 Peso seco da parte aérea, do sistema radicular e total, de plantas de maracujazeiro sadias, infectadas com três isolados do potyvírus causador de mosqueado em maracujazeiro (M1, M2 e M3) e com dois isolados do PWV (PWV-1 e PWV-2), em dois experimentos distintos, realizados em casa-de-vegetação.

10 Porcentagem de identidade entre as seqüências de nucleotídeos (diagonal inferior) e as sequências de aminoácidos deduzidos (diagonal superior) do gene da capa protéica dos isolados M2 e M3 do potyvírus causador de mosqueado em maracujazeiro e de mais 10 outros potyvírus

11 Porcentagem de identidade entre as seqüências do terminal 3' não traduzido dos isolados M2 e M3 do potyvírus causador de mosqueado em maracujazeiro e de mais 8 outros potyvírus. 


\title{
CARACTERIZAÇÃO BIOLÓGICA, SEROLÓGICA E MOLECULAR DE UMA ESTIRPE DO PASSION FRUIT WOODINESS VIRUS(PWV) QUE INFECTA SISTEMICAMENTE ALGUMAS CUCURBITÁCEAS
}

\author{
Autor: RICARDO GIORIA \\ Orientador: Prof. Dr. JORGE ALBERTO MARQUES REZENDE
}

\section{RESUMO}

Este trabalho apresenta resultados da caracterização biológica, serológica e molecular de um potyvirus que causa mosqueado foliar em maracujazeiro e infecta, experimentalmente, plantas de abobrinha-de-moita (Cucurbita pepo cv. Caserta). Esse potyvirus foi inicialmente observado em extratos de folhas de maracujazeiro e em cortes ultra finos de tecidos infectados de abobrinha-de-moita, em microscopia eletrônica. Além de partículas alongadas, observaram-se inclusões lamelares do tipo catavento, características de espécies de vírus do gênero Potyvirus. Após purificação a partir de folhas de maracujazeiro com mosqueado, as partículas desse potyvirus foram dissociadas para a caracterização dos seus principais componentes. O RNA viral apresentou peso molecular de aproximadamente $10000 \mathrm{pb}$. O peso molecular da proteína da capa protéica foi de aproximadamente $32 \mathrm{kDa}$. Antissoro policlonal produzido em coelho reagiu com o antígeno homólogo, bem como com o Passion fruit woodiness virus (PWV), 
em teste de PTA-ELISA, mas não reagiu com dois potyvirus que infectam cucurbitáceas, Papaya ringspot virus - type $\mathrm{W}$ e Zucchini yellow mosaic virus. $\mathrm{O}$ antissoro contra o PWV reagiu com o potyvirus do mosqueado do maracujazeiro. Quando três isolados do potyvirus do mosqueado do maracujazeiro (M1, M2 e M3) foram inoculados em 37 espécies vegetais, juntamente com dois isolados do PWV (PWV-1 e PWV-2), constatou-se que todas as espécies infectadas pelos isolados do PWV também o foram com os isolados do potyvirus do mosqueado. Estes últimos, entretanto, também foram capazes de infectar sistemicamente plantas de abobrinha-de-moita cv. Caserta e de abóbora híbrida do tipo Tetsukabuto, o que não ocorreu com os isolados do PWV. Testes de transmissão do isolado M1 do potyvirus do mosqueado, por meio mecânico e com os afídeos Myzus persicae e Aphis gossypii, de plantas de maracujazeiro, abobrinha-de-moita, feijoeiro BT 2 e crotalária, para plantas das mesmas espécies foram positivos. No entanto, observou-se que a eficiência de transmissão foi influenciada pela planta fonte de inóculo. Quando a abobrinha-de-moita foi utilizada como fonte de inóculo, a transmissão só ocorreu para plantas-teste dessa espécie, independente do processo de inoculação. Testes de proteção entre os isolados do potyvirus do mosqueado e do PWV, em plantas de Crotalaria juncea, juntamente com a análise da seqüência de nucleotídeos do gene da capa protéica e da região terminal 3' não traduzida dos isolados M2 e M3, indicaram que o potyvirus do mosqueado é uma estirpe do PWV que ocorre em São Paulo. Análises moleculares comparativas com outras espécies de Potyvirus indicaram que tanto os isolados do potyvirus do mosqueado como os isolados do PWV têm alta identidade com - Cowpea aphid-borne mosaic virus (CABMV). Esse resultado corrobora relato anterior feito no país e aponta para a necessidade de uma alteração na nomenclatura da espécie do vírus que está freqüentemente associada ao endurecimento dos frutos do maracujazeiro no Brasil. 


\title{
BIOLOGICAL, SEROLOGICAL AND MOLECULAR CHARACTERIZATION OF AN ISOLATE OF PASSION FRUIT WOODINESS VIRUS(PWV) THAT INFECT SOME CUCURBIT PLANTS SYSTEMICALLY
}

\author{
Author: RICARDO GIORIA \\ Adviser: Prof. Dr. JORGE ALBERTO MARQUES REZENDE
}

\section{SUMMARY}

This work presents results of the biological, serological and molecular characterization of a potyvirus that causes leaf mottling on passion fruit and infects some cucurbit plants experimentally. This potyvirus was initially observed in extracts of passion fruit leaves and in ultra thin sections of infected tissue of Cucurbita pepo L. cv. Caserta, examined in the electronic microscope. Besides flexuous filamentous particles, lamellar inclusions, characteristic of species of potyvirus, were observed in infected tissue. After purification from infected passion fruit leaves, virus particles were dissociated for the molecular characterization of their main components. The viral RNA showed a molecular weight of approximately $10000 \mathrm{bp}$. The molecular weight of the coat protein was nearly $32 \mathrm{kDa}$. Policlonal antibody, produced in rabbit, reacted with the homologous antigen, as well as with Passion fruit woodiness virus (PWV), in PTA-ELISA. No reaction was observed with Papaya ringspot virus - type $W$ and Zucchini yellow mosaic virus, two potyviruses usually found infecting plants in the Cucurbitaceae family. The antibody against PWV reacted with the passion 
fruit mottling potyvirus. When three isolates of the passion fruit leaf mottling potyvirus (M1, M2 and M3) and two isolates of PWV were separately inoculated in 37 vegetable species, it was verified that all the species infected with the PWV isolates were also infected with the isolates of the passion fruit leaf mottling potyvirus. Isolates M1, M2 and M3, however, were also capable to infect systemically plants of zucchini squash cv. Caserta and hybrid squash Tetsukabuto, which were not infected with the PWV isolates. Transmission tests showed that the M1 isolate of passion fruit leaf mottling potyvirus was efficiently transmitted from infected plants of passion fruit, zucchini squash, Phaseolus vulgaris cv. BT 2 and Crotalaria juncea to plants of the same species by means of mechanical inoculation. Efficient transmission was also obtained when the aphids Myzus persicae and Aphis gossypii were used as vectors. However, the transmission efficiency was influenced by the plant source of inoculum. When zucchini squash was used as a source of inoculum, the transmission only occurred for plants of the same specie, independent of the method of inoculation. Cross protection tests with isolates of the passion fruit leaf mottling potyvirus and PWV, in plants of $C$. juncea, together with the analysis of the nucleotide sequences of the coat protein $(C P)$ gene and the $3^{\prime}$ non translated region (NTR) of the isolates $M 2$ and $M 3$, indicated that the leaf mottling potyvirus has high identity with the PWV present in São Paulo State. As compared with other species of the genus Potyvirus, isolates of both potyviruses showed high identity with the CP gene and 3' NTR of Cowpea aphid-borne mosaic virus (CABMV). This result corroborates previous report regarding to the identity between Brazilian PWV isolates and CABMV and it points for the need of an alteration in the nomenclature of the virus species frequently associated to passion fruit woodiness in Brazil. 


\section{INTRODUÇÃO}

O Brasil é o maior produtor mundial de maracujá amarelo (Passiflora edulis Sims. f. flavicarpa Deg.), seguido de Peru, Colômbia, Índia e Quênia (FNP, 1998), com uma área plantada estimada, em 1999, em torno de 35.637 ha (FNP, 2002). As regiões Nordeste, com 18.000 ha e Sudeste, com 9.000 ha são as maiores produtoras, respondendo por aproximadamente $49 \%$ e $20 \%$ da área plantada no Brasil, respectivamente. Apesar do Nordeste representar a maior área produtora, é na região Norte que se encontra o maior estado produtor, o Pará, com aproximadamente $25 \%$ de toda área cultivada com maracujazeiros no Brasil (FNP, 1999). Praticamente a totalidade de frutos produzidos no território nacional se destina a produção de suco e à comercialização de frutas frescas.

Com o escalonamento da produção e conseqüentemente da receita para o produtor, em função da colheita de frutos em pelo menos nove meses do ano, a cultura dessa frutífera vem servindo de suporte econômico principalmente para pequenos agricultores. Dados fornecidos pelo CEAGESP, contabilizaram que, em 2001 comercializaram-se por volta de 19.000 ton. de maracujá, ao preço médio de aproximadamente $R \$ 0,90 / \mathrm{kg}$, sendo o maracujá azedo ou amarelo responsável por aproximadamente $94 \%$ deste volume, o que demonstra uma produção e um valor pago praticamente idênticos aos do ano de 1999 , onde foram comercializadas 19.750 ton ao preço de $R \$ 0,88 \mathrm{~kg}$.

Com a expansão da área cultivada em São Paulo, um dos fatores que se mostrou muitas vezes limitante para o desenvolvimento da cultura foi o associado a problemas fitossanitários, dentre os quais os de etiologia viral. Reduções drásticas na área cultivada com esta frutífera foram observadas, por 
exemplo, na região da Alta Paulista que no ano de 1996, com uma área plantada de 1.559 ha, respondia por mais de um terço do volume de frutos comercializados em São Paulo e hoje, com área cultivada praticamente reduzida a 1 oitavo da anteriormente relatada, esta perdendo o posto de um dos pólos de produção no estado (informação EDR/CATI, Marília, SP).

Até o presente momento, os vírus relatados em maracujazeiro no Brasil compreendem o do endurecimento dos frutos (Passion fruit woodiness virus- PWV), o do mosaico do pepino (Cucumber mosaic virus- CMV), o do clareamento das nervuras (Passion fruit vein clearing virus- PVCV), o do mosaico amarelo (Passion fruit yellow mosaic virus-PFYMV), o do mosaico do maracujá roxo (Purple granadilla mosaic virus-PGMV), o geminivirus causador de mosaico dourado e deformação foliar (Novaes et al., 2002) e finalmente o vírus causador da pinta verde do maracujazeiro (Passion fruit green spot virusPGSV) (Kitajima et al., 1986; Chagas, 1991; Rezende, 1994; Kitajima et al., 1997).

Inspeções recentes em maracujazais na região da Alta Paulista revelaram a presença de algumas plantas exibindo sintomas de mosqueado foliar, com pouca ou nenhuma redução ou alteração no limbo, sugerindo tratarem-se de infecções com possíveis estirpes fracas do PWV. Exames de microscopia eletrônica de algumas dessas amostras indicaram a presença de partículas semelhantes as de potyvírus. No entanto, estudos biológicos mostraram que esse vírus infectava sistemicamente plantas de abobrinha-demoita cv. Caserta, fato que o tornava aparentemente distinto do PWV. O presente trabalho visou à caracterização biológica, serológica e molecular e a avaliação do efeito deste potyvírus no desenvolvimento de plantas de maracujazeiro. 


\section{REVISÃO DE LITERATURA}

Entre as mais de 600 espécies denominadas de maracujá e pertencentes ao gênero Passiflora, aproximadamente um quarto são encontradas exclusivamente no Brasil, sendo que entre estas, mais de 60 produzem frutos que podem ser consumidos in natura ou na forma de sucos (Hoehne, 1946). Apesar desta quantidade de representantes da família Passifloraceae enfatiza-se, comercialmente, a condução e manejo de apenas três, o maracujá amarelo, peroba ou ácido (Passiflora edulis Sims. f. flavicarpa Deg.) que é o mais cultivado, o promissor maracujá doce, que está se tornando atualmente mais conhecido por maracujá alata em função do seu nome científico P. alata Ait. e o maracujá roxo (P. edulis Sims.) (Silva \& São José, 1994; Cereda \& Ferreira, 1998).

No Brasil, cinco gêneros de vírus já foram identificados possuindo espécies ocasionando doenças em maracujazeiro: o gênero Cucumovirus, com o vírus causador do mosaico do pepino (Colariccio et al., 1987); o gênero Potyvirus, com o vírus causador do endurecimento dos frutos (Yamashiro \& Chagas, 1979; Chagas et al., 1981); o gênero Rhabdovirus, com dois representantes causando doenças distintas, o clareamento das nervuras (Batista et al., 1981) e a pinta verde do maracujazeiro (Kitajima et al., 1997); o gênero Tymovirus, com o vírus causador do mosaico amarelo (Crestani et al., 1984; Crestani et al., 1986) e o gênero Begomovirus (Novaes et al., 2002). Acrescenta-se ainda o vírus causador do mosaico do maracujá roxo, cuja posição taxonômica não se encontra definida (Chagas et al., 1984). Atualmente, em caráter mundial acrescentam-se a lista dos gêneros virais que possuem espécies associados a doenças em maracujazeiros os gêneros Carlavirus 
(Pares et al., 1997), Nepovirus (Koeing \& Fribourg, 1986) e Tobamovirus (Fribourg et al., 1987).

Com relação às viroses relatadas no Brasil, importância deve ser dada principalmente a causada pelo PWV, cuja primeira constatação acorreu em plantios comerciais de maracujá amarelo e P. alata, no Estado da Bahia, no final da década de 70 (Chagas et al., 1981; Yamashiro \& Chagas, 1979) e posteriormente nos Estados de Pernambuco (Loreto \& Vital, 1983), Sergipe, Ceará (Kitajima et al., 1986), São Paulo (Chagas et al., 1992), Minas Gerais (São José et al., 1994), Distrito Federal (Inoue et al., 1995) e Pará (Trindade et al., 1999). A recente introdução do PWV no Pará ocorreu, provavelmente, via mudas contaminadas oriundas dos Estados da Bahia e Minas Grais.

O PWV pertence ao gênero Potyvirus, família Potyviridae, cujas partículas do tipo flexuosa medem $670-750 \mathrm{~nm}$ de comprimento por 12 - $15 \mathrm{~nm}$ de diâmetro. Apresenta RNA de fita simples, positiva, e produz inclusões citoplasmáticas lamelares na configuração de cata-vento (Taylor \& Greber, 1973; Van Regenmortel et al., 2000). Não é transmitido por sementes de maracujazeiro, porém há um relato de sua transmissão por sementes de feijoeiro (Phaseolus vulgaris L. cv. Preto 153) (Costa, 1985). No campo, a transmissão natural se dá por meio de afídeos, principalmente Myzus persicae Sulz. e Aphis gossypii Glover (Chagas et al., 1981), sendo a relação vírus-vetor do tipo não persistente (Taylor \& Greber, 1973). Outras espécies de afídeos já foram demonstradas como potenciais transmissoras do PWV como Aphis fabae solanella Theobald, Toxoptera citricidus Kirk., Uroleucon ambrosiae Thomas e U. sonchi L. (Costa el al., 1995).

Estudos recentes com base em análises comparativas da seqüência de nucleotídeos e de aminoácidos do gene da capa protéica do vírus denominado por PWV no Brasil, demonstraram que este possui alta identidade, superior a 85\%, com o South African passiflora virus (SAPV) e o Cowpea aphidborne mosaic virus (CABMV). Atualmente, sabe-se que o SAPV é uma estirpe do CABMV (Van Regenmortel et al., 2000). Paralelamente, comparações 
efetuadas com isolados australianos do PWV apontaram identidade de $70 \%$, aproximadamente (Braz et al., 1998; Santana et al., 1999). A identidade apresentada entre os isolados brasileiros do PWV e o CABMV é superior a mínima necessária para agrupar estes vírus na mesma espécie de Potyvirus, de acordo com os critérios estabelecidos pelo International Committe of Virus Taxonomy (Van Regenmortel et al., 2000). É provável que investigações adicionais acabem por propor futuras alterações na nomenclatura dos isolados brasileiros do vírus causador de endurecimento nos frutos do maracujazeiro.

Os maracujazeiros infectados com o PWV apresentam sintomas generalizados de mosaico foliar, com intensidade variável, podendo vir acompanhado de bolhas, rugosidade e deformações foliares. As plantas apresentam crescimento retardado, bem como o encurtamento dos entrenós, além da produção de frutos menores, deformados e com o pericarpo endurecido e com espessura irregular (Pio-Ribeiro \& Mariano, 1997; Rezende, 1994). Os sintomas da doença nos frutos não são específicos da infecção com - PWV, sendo de valor reduzido para diagnóstico. O endurecimento e deformação de frutos é relatado em infecções ocasionadas pelo CMV (Taylor \& Kimble, 1964; Colariccio et al., 1987) além de insetos e fatores nutricionais também poderem ocasionar estes tipos de sintomatologia.

Os prejuízos causados pelo PWV na cultura do maracujazeiro são considerados graves na Austrália e em Pernambuco, onde se atribuiu a ele queda de produtividade e redução na área cultivada e na vida econômica do pomar (Peasley \& Fitzell, 1981; Pares et al., 1985; Costa et al., 1995). Em São Paulo, estudos sobre o efeito do PWV no desenvolvimento e na produção do maracujazeiro e a incidência deste vírus em pomares localizados na região produtora da Alta Paulista foram realizados por Gioria et al. (2000). Em casade-vegetação, plantas inoculadas mecanicamente com 4 estirpes do PWV oriundas de São Paulo, Minas Gerais, Pernambuco e Ceará apresentaram redução na área foliar da ordem de 50\%, quando comparadas com plantas sadias da mesma idade. Em experimento em telado, plantas inoculadas 
mecanicamente aos 2, 4 e 6 meses após o plantio, com um isolado do PWV de Vera Cruz (SP), apresentaram, aos doze meses, estabilização do índice de área foliar (IAF) ao redor de 4,4, 3,8 e 5,6, respectivamente. Neste mesmo período, as plantas sadias que foram infectadas entre 7 e 8 meses após o plantio, mostraram valor 10,0 de estabilização do IAF. A colheita dos frutos, realizada durante 5 meses, indicou que as plantas infectadas aos 2, 4, 6 e entre 7 e 8 meses produziram, em média, 2,4, 3,4, 6,9 e 12,9 kg, respectivamente. Os dados referentes à incidência do PWV na região produtora da Alta Paulista apontaram para valores próximos de $72 \%$. Valores semelhantes de incidência do PWV (73,1\%) foram detectados por Lima et al. (1996) na região produtora da Serra da Ibiapaba, Ceará.

Experimentalmente o PWV infecta pelo menos 44 espécies de dicotiledôneas, sendo um quarto delas espécies de Passiflora e quase $50 \%$ de leguminosas. No Brasil, além do maracujazeiro amarelo (Passiflora edulis $\mathrm{f}$. flavicarpa), o PWV já foi relatado infectando naturalmente o maracujá doce $(P$. alata Dryand.) (Yamashiro \& Chagas, 1979) e o maracujá-de-rato ( $P$. nítida HBK) (Moraes et al., 2002). Experimentalmente, esse vírus já foi transmitido para maracujá-catinga ( $P$. foetida Linn.) (Rezende, dado não publicado) e para 3 híbridos interespecíficos de Passiflora sp. (Novaes et al., 2000). Fora da família Passifloraceae, o PWV já foi transmitido experimentalmente para espécies das famílias Leguminosae e Chenopodiaceae. Gioria e Rezende (1996) realizaram extensivos estudos de hospedeiras de 6 isolados brasileiros do PWV e constataram infecção sistêmica em Canavalia brasiliensis Marth., $C$. ensiformis D.C. , Cassia occidentalis (L.) Link, Crotalaria juncea, C. striata L., Glycine max (L.) Merr. cv. Santa Rosa, Macropitilum lathyroides L., Tremoço branco, Phaseolus lunatus L. cvs. Fava Branca Achatada e Fava Jackson Wounder, P. vulgaris L. cvs. Black Turtle 2, Preto 62 (hipersensível) e Rosinha G2. Sintomas locais foram encontrados em $C$. brasiliensis, Chenopodium amaranticolor Costa \& Reyn, P. vulgaris cvs. Carnaval, Grand Precoce, Jalo e 
Manteiga. Trinta e uma outras espécies/ variedades testadas, entre elas Cucurbita pepo cv. Caserta e Vigna unguiculata L. não foram infectadas. Santana (2001) relatam infecção sistêmica de $V$. unguiculata com isolados provenientes de 6 estados brasileiros mais do Distrito Federal. Há ainda relato da infecção sistêmica em amendoim (Arachys hypodeae L.) e da transmissão do PWV pelas semente P. vulgaris cv. Preto 153 (Costa, 1985).

De ocorrência em maracujazais no Brasil e ainda merecedoras de destaque pelos constantes relatos de incidência e danos associados à cultura em meados da década de 90, pode-se citar o CMV e o PGSV, respectivamente. O sintomas causados pelo CMV em maracujazeiros caracterizam-se pela presença de mosaico amarelo intenso, acompanhados de anéis e/ou semianéis além de deformações foliares em alguns casos (Rezende, 1994). O CMV, a princípio, poderia assumir importante papel nos pomares de maracujazeiros devido ao fato desse vírus ser de distribuição mundial, infectar centenas de espécies vegetais e ser transmitido de forma não persistente por inúmeros afídeos. Apesar de todas estas características, inspeções periódicas em maracujazais, feitas pelo signatário, indicaram que a infecção com o CMV não parecia ocasionar danos significativos à produção, pois se mostrava limitada a porções da rama. No geral, notava-se que os sintomas ocasionados pelo CMV apareciam em um número pequeno e limitado de folhas do ramo e desapareciam com o desenvolvimento deste. Estudos realizados por Gioria et al. (2002), para melhor compreensão desse fenômeno, demonstraram que em maracujazeiro amarelo o CMV tem sua distribuição restrita as regiões sintomáticas, havendo remissão de sintomas e desaparecimento do vírus nas áreas assintomáticas. @s resultados desse trabalho demonstraram a pequena importância do CMV para a cultura do maracujazeiro, principalmente pelo patógeno ficar restrito a pequenas porções do ramo.

O PGSV, em meados da década de 90, causou danos de até $100 \%$ em áreas produtoras de maracujazeiro da região da Alta Paulista (Kitajima et 
al., 1997). Os danos observados foram associados a um desbalanço na população do ácaro vetor (Brevipalpus phoenicis Geijskes), principal vetor do PGSV. A presença do ácaro na cultura era responsável por danos consideravelmente maiores quando o mesmo estava infectado pelo PGSV. Em função da infecção com o vírus da pinta verde do maracujazeiro ficar restrita ao local de alimentação do ácaro vetor, a adoção de medidas para o controle deste restabeleceram o seu equilíbrio populacional e, eliminaram o problema na cultura. Em levantamento efetuados posteriormente a adoção de medidas de controle do vetor, a incidência do PGSV foi aparentemente inexpressiva (Gioria et al., 2000).

Para os demais vírus relatados em maracujazeiros no Brasil, o PFYMV e o PGMV parecem ter ficado, até o momento, restritos aos respectivos locais de primeiro relato. O Begomovírus recentemente encontrado em maracujazeiros no estado da Bahia (Novaes et al., 2002), apesar de aparentemente altamente agressivo, ainda se encontra restrito a área de relato.

Inspeções mais recentes em pomares de maracujazeiro na região da Alta Paulista indicaram a presença de plantas com sintomas de mosqueado foliar, com poucas alterações morfológicas no limbo (Figura 1), diferente dos sintomas causados pelos vírus até então relatados em plantas dessa frutífera. Exames preliminares em microscopia eletrônica revelaram que os sintomas estavam associados a partículas típicas do gênero Potyvirus (Figura 2). Testes de transmissão mecânica indicaram que esse vírus infectava, sistemicamente, plantas de abobrinha-de-moita (Cucurbita pepo L. cv. Caserta) (Figura 3), espécie não relatada como hospedeira para o PWV, o único potyvírus até então relatado no Brasil infectando maracujazeiros.

A infecção de maracujazeiros por outras espécies putativas de vírus do gênero Potyvirus, distintos do PWV, já foi relatada na Austrália, em Taiwan, na África do Sul e na Colômbia. Na Austrália, um vírus designado como Passion fruit ringspot virus (PFRSV) foi relatado como distinto, porém serologicamente relacionado ao PWV (Wijs, 1974). A presença desse vírus foi constatada em 


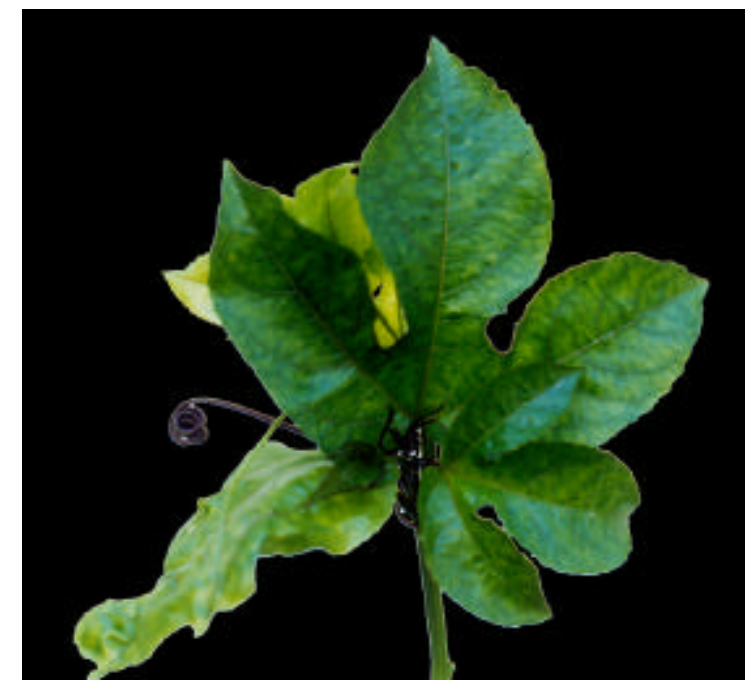

Figura 1 - Sintoma de mosqueado em planta de maracujazeiro amarelo

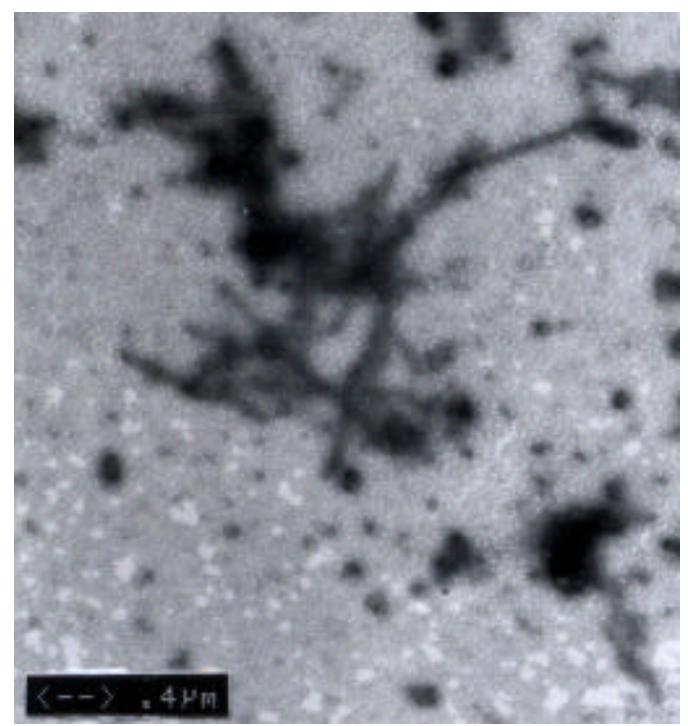

Figura 2 - Micrografia eletrônica de 'leaf dip', exibindo partículas virais alongadas, típicas do gênero Potyvirus, encontradas em amostras de plantas de abobrinha-de-moita 'Caserta' inoculadas com extratos de plantas de maracujazeiro apresentando sintomas de mosqueado foliar 


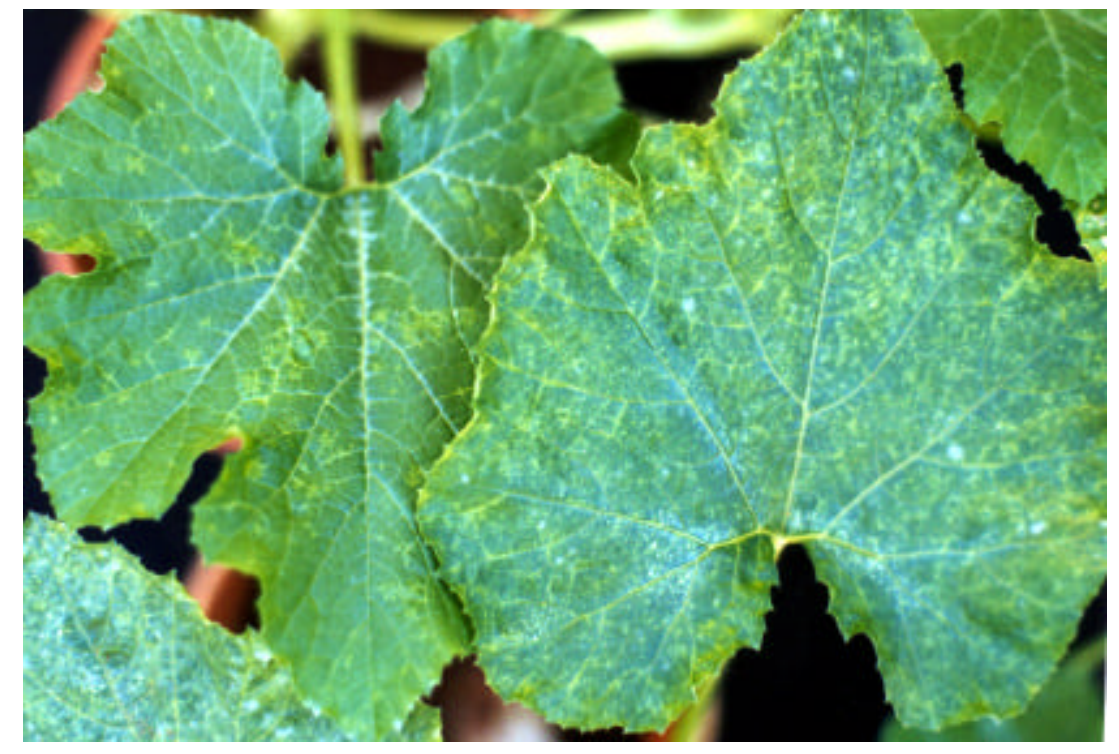

Figura 3 - Sintoma de amarelecimento de nervuras apresentado por planta de abobrinha-de-moita 'Caserta' inoculada com extrato foliar de planta de maracujazeiro exibindo sintoma de mosqueado 
função da ocorrência de dois sintomas típicos observados, concomitantemente, em maracujazais. Um primeiro sintoma, confirmado como sendo causado pelo PWV, se resumia a presença de mosaico severo, mal formação foliar e frutos endurecidos. Um segundo tipo, posteriormente associado ao designado PFRSV, era caracterizado por apenas um mosqueado foliar e formação de anéis em folhas jovens, não sendo observadas deformações e mosaico severo, nem frutos endurecidos. Em Taiwan, uma outra suposta espécie de potyvírus denominada Passion fruit mottle virus (PFMoV) foi isolada de plantas de maracujazeiro do cultivar Tainung $n . \stackrel{1}{1}$, apresentando mosqueado fraco $\mathrm{e}$ ausência de endurecimento de frutos (Chang, 1992). O PFMoV foi biologicamente distinto do vírus do endurecimento dos frutos, infectando dbis cultivares de feijão ('Sutter pink' e 'Dubbele witte') resistentes ao PWV, porém testes de imunodifusão em ágar-SDS mostraram a existência de relacionamento serológico entre esses potyvirus. A utilização do ELISA direto permitiu demonstrar que a distribuição dos dois vírus, nos pomares de Taiwan, foi praticamente a mesma, além de revelar infecções mistas que demonstram a não existência de proteção cruzada. Embora os sintomas do PFMoV sejam menos drásticos do que os do PWV, por não ocasionar distorções foliares e endurecimento de frutos, o vigor da planta pode ser gradualmente reduzido, chegando praticamente a não produzir frutos no término do primeiro ano da cultura. Por esta razão, em Taiwan, a importância do PFMoV para a indústria não é menor do que aquela constatada para o PWV (Chang, 1992).

$\mathrm{Na}$ África do Sul, uma estirpe do Cowpea aphid-borne mosaic virus (CABMV), designada South African passiflora virus, foi relatada causando infecção em maracujazeiros (Brand et al., 1993). Na Colômbia, Benscher et al. (1996) relataram a infecção de maracujazeiro com uma estirpe do vírus do mosaico da soja (Soybean mosaic virus- SMV) causando mosaico severo, epinastia, desfolha e morte das plantas. 


\section{MATERIAL E MÉTODOS}

\subsection{Plantas-teste}

A maioria dos estudos foram conduzidos em casa-de-vegetação, no Setor de Fitopatologia do Departamento de Entomologia, Fitopatologia e Zoologia Agrícola, da Escola Superior de Agricultura "Luiz de Queiroz", utilizando-se plantas de maracujazeiro amarelo ( $P$. edulis f. flavicarpa), de abobrinha-de-moita (C. pepo L. cv. Caserta), de feijão preto (Phaseolus vulgaris L.) Cv. BT-2 e de crotalária (Crotalaria juncea L.).

Com o objetivo de ter constante disponibilidade de plantas-teste, as semeaduras foram feitas a intervalos de 15 a 20 dias. Para isso foram utilizados vasos de alumínio de $16 \mathrm{~cm}$ de altura por $14,5 \mathrm{~cm}$ de diâmetro de boca, cheios com uma mistura de três partes de terra, uma de areia média e uma de esterco de curral curtido. Tanto os vasos como a terra empregada para o plantio foram autoclavados a $121^{\circ} \mathrm{C}$ por 2 horas. Foram mantidas 2 plantas de cada espécie por vaso e efetuourse quinzenalmente adubações com aproximadamente 2 gramas de sulfato de amônia por vaso.

\subsection{Isolados dos vírus}

Foram empregados três isolados do potyvírus designado como causador do mosqueado em maracujazeiro (M1, M2, e M3) e dois isolados do PWV (PWV-1 e PWV-2), todos oriundos da região da Alta Paulista. Os isolados do PWV e do potyvírus do mosqueado foram primeiramente inoculados em Chenopodium quinoa Willd. e C. amaranticolor Coste \& Reyn., respectivamente, 
para se obter isolados puros a partir de lesão local. Os cinco isolados virais empregados foram posteriormente mantidos em plantas de maracujazeiros. Com a finalidade de manter fontes de inóculo de boa qualidade, os isolados foram freqüentemente transmitidos mecanicamente para novas plantas-teste.

Além dos isolados acima citados foram empregados apenas para testes de relacionamento serológico um isolado do Zucchini yellow mosaic vírus (ZYMV) e um do Papaya ringspot vírus- type W (PRSV-W) ambos oriundos de abobrinha-de-moita, mantida em casa-de-vegetação.

\subsection{Inoculação mecânica}

Para a inoculação mecânica dos isolados do potyvírus do mosqueado do maracujazeiro e do PWV, os inóculos foram obtidos separadamente, através da maceração de folhas infectadas em almofariz, em presença de tampão de fosfato de potássio $0,02 \mathrm{M}, \mathrm{pH} 7,0$, acrescido de sulfito de sódio com a mesma molaridade, na diluição de 1:20 (peso:volume). As inoculações foram feitas nas folhas das plantas-teste previamente polvilhadas com carbureto de silício, friccionando-as com o dedo indicador umedecido no inóculo. Em seguida as folhas foram lavadas para a retirada do excesso de abrasivo e de inóculo.

\subsection{Gama de hospedeiras}

Para os testes da gama de hospedeiras foram empregadas espécies das famílias Aizoaceae, Amaranthaceae, Chenopodiaceae, Compositae, Cucurbitaceae, Leguminosae e Solanaceae, num total de 37 espécies listadas na Tabela 2 (item 4.3 dos resultados). O plantio e manutenção das plantas foi idêntico ao detalhado para as plantas-teste no item 3.1. Todas as plantas-teste foram inoculadas separadamente com os 3 isolados do potyvírus do mosqueado (M1, M2 e M3) e os dois isolados do PWV (PWV-1, PWV-2) de 
maneira mecânica, como descrito no item 3.3. Decorridos 15 dias da inoculação efetuourse análise visual de sintomas e amostras foliares foram retiradas para a comprovação ou não de infecção empregando testes serológicos de PTAELISA e/ou 'Western blot'.

\subsection{Microscopia eletrônica}

Para a observação de cortes ultra finos de tecidos foliares de plantas doentes foi utilizada a metodologia descrita por Kitajima \& Nome (1999). As amostras foliares foram cortadas em pequenos fragmentos de 1 a $3 \mathrm{~mm}^{2}$ e préfixadas em solução de Karnovsky modificada (glutaraldeído 2,5\%, paraformaldeído 2,5\% em tampão cacodilato ou fosfato $0,05 \mathrm{M}, \mathrm{pH} 7,2$ ) por pelo menos 60 minutos. Promoveu-se a lavagem do tecido pré-fixado em tampão cacodilato $0,05 \mathrm{M}$, por 10 minutos, três vezes consecutivas. Para pós-fixação utilizou-se $\mathrm{OsO}_{4} 1 \%$ em tampão cacodilato $0,05 \mathrm{M}$ por 1 a 2 horas. Decorrido este período lavou-se a amostra com água destilada, fixando-a, em seguida, com acetato de uranila $1 \%$ durante uma noite. A amostra fixada foi desidratada em acetona (uma vez, por 10 minutos, em acetona 30, 50, 70, 90\%, respectivamente, e três vezes por 10 minutos em acetona 100\%) e filtrada com mistura 1:1 de acetona/ Spurr por 3 a 4 horas, e posteriormente apenas com Spurr durante a noite. $\mathrm{O}$ tecido fixado foi colocado em formas de silicone cheias de resina Spurr pura, cuja polimerização foi feita em estufa a $70^{\circ} \mathrm{C}$, durante 48 horas.

Obtiveram-se cortes ultra-finos (50 - $100 \mathrm{~nm}$ ) em ultramicrótomo Reicher, Ultracut E com navalha de diamante Diatone. Estes foram colocados em telinhas de microscopia eletrônica, contrastando-se as secções em acetato de uranila $3 \%$ por 15 minutos e citrato de chumbo por 10 minutos. As telinhas foram lavadas através da imersão (20 vezes) em água destilada, repetindo-se o procedimento três vezes consecutivas. Examinaram-se os cortes em 
microscópio eletrônico de transmissão Zeiss EM 900, do NAP/MEPA, ESALQ/USP.

A microscopia eletrônica também foi utilizada para o monitoramento do processo de purificação do potyvírus causador de mosqueado em maracujazeiro e determinação da integridade das partículas virais. Uma gota de suspensão purificada do vírus foi colocada sobre um pedaço de "parafilm". Sobre esta gota foi colocada uma telinha de microscopia eletrônica de transmissão. Após 3 a 5 minutos a telinha foi removida e lavada em água destilada, três vezes consecutivas. A contrastação foi feita com solução de acetato de uranila $1 \%$ durante 2 a 3 minutos.

\subsection{Purificação do potyvírus causador de mosqueado em maracujazeiro}

Para a purificação do potyvírus causador do mosqueado foi utilizada metodologia descrita por Marinho \& Kitajima (1989) com algumas modificações, sendo o vírus multiplicado em plantas de maracujazeiro amarelo. A purificação foi feita a partir de folhas sistemicamente infectadas, 20 dias após a inoculação mecânica das plantas. As folhas foram trituradas em liquidificador, em presença de duas partes de tampão fosfato $0,25 \mathrm{M}, \mathrm{pH}$ 7,5 contendo 0,01 M de Na-EDTA e $0,1 \%$ de ácido tioglicólico. O homogeneizado foi filtrado em gaze e centrifugado a $3.000 \mathrm{rpm}$ por 10 minutos (rotor GSA - Sorvall) e ao sobrenadante colhido foram adicionados $1 \%$ de triton $X-100,4 \%$ de polietilenoglicol (PEG) e 0,1 M NaCl. Promoveu-se uma agitação por duas horas e meia a 4ำ e posteriormente uma nova centrifugação a 9.000 rpm por 15 minutos (rotor GSA - Sorvall). O precipitado foi dissolvido em tampão fosfato 0,25 M, pH 7,5 contendo 0,01 M de $\mathrm{MgCl}_{2}$ e centrifugado a $29.000 \mathrm{rpm}$ por uma hora e meia (rotor T30- Beckman). O precipitado resultante foi dissolvido em tampão fosfato $0,01 \mathrm{M}, \mathrm{pH}$ 7,0 e centrifugado a 9.000 rpm por 10 minutos (rotor GSA - Sorvall). O sobrenadante coletado foi submetido a uma centrifugação de 30.000 rpm (rotor SW41 - Beckman) por 16h, em um gradiente isopícnico de 
cloreto de césio (CsCl) a 15\%, colocado sobre um colchão (3 mL), também de $\mathrm{CsCl}$ a $53 \%(\mathrm{p} / \mathrm{p})$, dissolvido em tampão fosfato $0,01 \mathrm{M}, \mathrm{pH} 7,0$. A banda resultante foi submetida a diálise em tampão fosfato $0,001 \mathrm{M}, \mathrm{pH} 7,0$. A concentração viral foi determinada em espectrofotômetro de luz ultravioleta, utilizando-se comprimento de onda na faixa de 230 a $320 \mathrm{~nm}$ e coeficiente de extinção $\left(E_{260}\right)$ de 2,4 (Chen, 1992). O armazenamento do isolado purificado foi efetuado $\mathrm{a}-20^{\circ} \mathrm{C}$.

Para avaliar a pureza da suspensão purificada e a integridade das partículas virais, amostras foram examinadas em um microscópio de transmissão Zeiss EM 900 do núcleo de microscopia eletrônica da ESALQ/USP.

\subsection{Produção de antissoro}

Para a produção de antissoro contra o potyvírus do mosqueado foram utilizadas êmeas de coelhos da raça Nova Zelândia, com aproximadamente 4 meses de idade, cedidas pelo Biotério da UNESP, Botucatu, SP, seguindo metodologia descrita por Bezerra et al. (1995) com algumas modificações. A preparação viral purificada foi emulsionada com adjuvante incompleto de Freund na proporção de 1:1, sendo a mistura injetada via intramuscular na coxa do coelho. Semanalmente foi aplicado $1 \mathrm{~mL}$ da emulsão contendo $100 \mu \mathrm{g}$ do vírus, em um total de 6 imunizações. Dez dias após a última injeção, o sangue foi coletado duas vezes, em intervalo de uma semana entre cada coleta, através de cortes feitos na veia marginal da orelha do coelho. Foram coletadas amostras de sangue de aproximadamente $25 \mathrm{~mL}$, promovendo-se a coagulação das mesmas a $4^{\circ} \mathrm{C}$ por 12 horas, seguida de uma centrifugação a $3.000 \mathrm{~g}$ por 10 minutos, para obtenção do soro sangüíneo. O soro coletado foi novamente centrifugado a $10.000 \mathrm{~g}$ por 10 minutos e transferido para recipientes de vidro que foram etiquetados e armazenados a $-20^{\circ} \mathrm{C}$. 


\subsection{Testes de transmissão}

Foram efetuados testes de transmissão mecânica e por afídeos para a determinação da eficiência da transmissão do potyvírus causador de mosqueado em função da espécie vegetal utilizada como fonte de inóculo.

\subsubsection{Efeito da espécie fonte de inóculo na eficiência da transmissão mecânica}

Para os testes de eficiência da transmissão mecânica foram utilizados inóculos do isolado M1 do potyvírus causador de mosqueado provenientes de plantas de maracujazeiro amarelo, abobrinha-de-moita, feijão preto $(P$. vulgaris L.) Cv. BT-2 e crotalária (C. juncea L.) sistemicamente infectadas. Cada um dos extratos obtidos dessas plantas foi inoculado em plantas- teste das mesmas espécies. Quinze dias após a inoculação foram efetuadas análise visuais de sintomas e utilizados os testes serológicos de PTA-ELISA e/ou 'Western blot' para comprovação de infecção.

\subsubsection{Efeito da espécie fonte de inóculo na eficiência de transmissão por afídeos}

Foi estudado o efeito da espécie fonte de inóculo na eficiência de transmissão do isolado M1 do potyvírus do mosqueado do maracujazeiro empregando duas espécies de afídeos, Myzus persicae Sulz. e Aphis gossypii Glover. As plantas fontes de inóculo para a aquisição do vírus pelos afídeos foram as mesmas descritas no item anterior. A transmissão foi avaliada em plantas de maracujazeiro amarelo, abobrinha-de-moita cv. Caserta, feijão preto CV. BT-2 e crotalária. Colônias livres de vírus das duas espécies de afídeos foram obtidas de criações feitas em plantas de rabanete selvagem (Raphanus raphanistrum L.) e maria-pretinha (Solanum americanum Mill.), 
respectivamente. Para os testes de transmissão, cada espécie de afídeo foi retirada da planta com o auxílio de um pincel fino e macio e os indivíduos colocados em jejum, numa caixa plástica, por um período de 1 hora, aproximadamente. A seguir, os afídeos foram colocados sobre folhas das plantas fontes, infectadas com o potyvírus do mosqueado. O período de aquisição do vírus foi de cerca de 10 minutos. Depois disso, com o auxílio do pincel, 5 indivíduos foram transferidos para cada planta-teste das diferentes espécies. Na manhã seguinte, as plantas foram pulverizadas com um fosforado sistêmico e foram mantidas em casa-de-vegetação por um período de 4 semanas, quando então foram indexadas por sintomas e testes de PTA-ELISA e/ou 'Western blot'.

\subsubsection{Efeito da idade das folhas de abobrinha-de-moita na aquisição e transmissão por afídeos}

Foram conduzidos estudos para a determinação da eficiência de transmissão do vírus causador de mosqueado em maracujazeiro empregando como fontes de inóculo folhas de abobrinha-de-moita cv. Caserta em 3 estádios de desenvolvimento [início de desenvolvimento (ID), parcialmente expandida (PE) e folha madura (FM)]. Neste experimento foram empregadas as mesmas espécies de afídeos e a mesma metodologia de aquisição detalhada no item anterior.

Após a aquisição os afídeos foram colocados em plantas-teste de abobrinha-de-moita e de maracujazeiro para efetuarem a transmissão. Após um período de 4 semanas efetuourse a indexação das plantas através da avaliação visual de sintomas e testes de PTA-ELISA e/ou 'Western blot'. 


\subsection{Determinação do peso molecular da proteína da capa protéica}

A análise da proteína da capa protéica viral foi feita através de eletroforese em gel de poliacrilamida contendo SDS. A identidade da proteína foi feita através da reação serológica, em teste de 'Western blot', após transferência das proteínas do gel para membrana de nitrocelulose (Conci, 1999).

Inicialmente foram extraídas as proteínas totais das amostras foliares e do purificado viral, em tampão TE 1 X (TRIS 1,0 M, pH 7,4, EDTA 0,5 M, pH 8,0) na proporção de $0,1 \mathrm{~g}$ de folhas ou $0,10 \mu \mathrm{L}$ de purificado viral para $200 \mu \mathrm{L}$ de tampão. Duzentos $\mu \mathrm{L}$ desta suspensão foram misturados com igual volume de tampão de dissociação (TRIS 0,5 M, pH 6,8, SDS 3,8\%, B-mercaptoetanol $10 \%$, azul de bromofenol $0,1 \%$, glicerol 19\%). A dissociação das proteínas foi completada incubando-se as amostras em água fervente, por 5 minutos, seguida de centrifugação a 5.000 rpm por 5 minutos.

As amostras foram submetidas à eletroforese em gel de poliacrilamida contendo dodecil sulfato de sódio (SDS-PAGE), utilizando-se um aparelho 'Bio Rad Mini Protean II'. O gel de separação foi composto por acrilamida 12,5\%, água destilada, TRIS $1,5 \mathrm{M}$, pH 8,8, SDS $0,1 \%$, APS 0,05\% e TEMED e o gel de empilhamento por acrilamida 4\%, água destilada, TRIS 1,0 M, pH 6,8, SDS $0,1 \%$, APS $0,076 \%$ e TEMED. Cada canaleta do gel recebeu $10 \mu \mathrm{L}$ da amostra a ser analisada. Uma canaleta recebeu $10 \mu \mathrm{L}$ de proteínas marcadoras, com peso molecular na faixa de $10 \mathrm{kDa}$ a $250 \mathrm{kDa}$ (Raimbow, Amersham LIFE SCIENCE). Foi efetuada a eletroforese por 20 minutos a 95 Volts, até a linha frontal do azul de bromofenol atingir o gel separador. Em seguida a voltagem foi elevada para 125 Volts. A corrida foi interrompida quando as amostras chegaram na base do gel.

As proteínas separadas no gel de poliacrilamida foram transferidas para uma membrana de nitrocelulose, empregando-se tampão de transferência (TRIS 0,3\%, glicine 1,5\%, metanol 20\%). A transferência foi feita em um 
aparelho "Bio Rad Mini trans-blot cell", por 90 minutos a 0,25 mA. A membrana contendo as proteínas das amostras foi submetida a uma reação serológica de 'Western blot', a fim de revelar a presença da proteína da capa protéica do vírus analisado. Inicialmente a membrana foi lavada por 2 a 3 minutos com TBS (TRIS 0,002 M, pH 7,4, NaCl 0,15 M)/Tween 20 (0,05\%). Em seguida foi incubada em TBS/Tween contendo $7,5 \%$ de leite em pó desnatado, por 30 minutos, à temperatura ambiente. A membrana foi transferida para uma suspensão de anticorpo específico contra o potyvírus testado, diluído 1:1.000, em TBS/Tween contendo leite em pó desnatado $7,5 \%$, incubando-a sob agitação constante, durante 3 - 4 horas, à temperatura ambiente. A membrana foi lavada por 2 a 3 minutos, 3 vezes, consecutivamente, com TBS/Tween. A seguir a membrana foi incubada, por 2 - 3 horas, sob agitação constante, à temperatura ambiente, em uma solução contendo imunoglobulina $\mathrm{G}$ ( $\lg \mathrm{G}$ ) conjugada com fosfatase alcalina (SIGMA A-8025), diluída 1:32.000 em TBS/Tween + leite em pó desnatado 7,5\%. Depois desse período a membrana foi lavada 2 a 3 vezes em TBS/Tween, durante 2 a 3 minutos cada vez. Finalmente foi adicionado o substrato 5-bromo-4-cloro-3-indolyl fosfato/nitro blue tetrazolium, pH 9,5 (NBT/BCIP - SIGMA B-5655), diluído em água destilada na proporção de uma pastilha de NBT/BCIP para $10 \mathrm{~mL}$ de água. A reação foi parada lavando-se a membrana com água destilada.

A técnica serológica de 'Western-blot' foi também utilizada nos estudos relativos a determinação de relacionamento serológico entre o vírus causador de mosqueado e o PWV e para a comprovação de infecção de algumas plantas nas inoculações efetuadas para determinação da gama de hospedeiras. 


\subsection{Isolamento do RNA viral, quantificação e determinação do peso molecular}

O isolamento do RNA viral foi realizado utilizando-se o protocolo proposto por Berger \& Shiel (1998). Um volume de $200 \mu \mathrm{L}$ do vírus purificado, acrescido de SDS a $1 \%(\mathrm{v} / \mathrm{v})$, foi incubado em banho-maria a $55^{\circ} \mathrm{C}$, sendo posteriormente agitado vigorosamente e centrifugado a 10.000 rpm por 2 minutos. A fase aquosa foi removida para um novo tubo, ao qual foi adicionado igual volume de clorofórmio isoamílico (24:1), agitando-se vigorosamente e centrifugando-se a $10.000 \mathrm{rpm}$, por 1 minuto. A fase aquosa foi removida e estimado o seu volume. A esta adicionaram-se 0,5 volume de acetato de amônio 7,5 M e 2,5 volumes de etanol a $-20^{\circ} \mathrm{C}$. O volume foi misturado e colocado a $-20^{\circ} \mathrm{C}$ pr 1 hora. Uma nova centrifugação a 12.000 rpm por 25 minutos a $4 \stackrel{\circ}{ } \mathrm{C}$ foi realizada, salvando o precipitado. Foi adicionado um volume de etanol $70 \%$ e imediatamente foi centrifugado a 12.000 rpm por 5 minutos. 0 precipitado foi ressuspendido em um pequeno volume de água tratada com DEPC.

A quantificação do RNA viral foi realizada pela leitura em espectrofotômetro nos comprimentos de onda de 260 e $280 \mathrm{~nm}$, considerando que $1 \mathrm{OD}_{260}$ equivale a $40 \mu \mathrm{g} / \mathrm{mL}$ de RNA de fita simples (Maniatis et al., 1989). O produto resultante foi armazenado a $-80^{\circ} \mathrm{C}$.

Para a determinação do peso molecular do RNA viral, alíquota de $5 \mu \mathrm{L}$ do RNA purificado foi submetida à eletroforese em gel de agarose $1 \%$, contendo $0,5 \mu \mathrm{g} / \mathrm{mL}$ de brometo de etídeo, utilizando-se como padrão um marcador de peso molecular de $1 \mathrm{~Kb}$ (DNA ladder, Promega). A visualização do gel de agarose foi efetuada sob luz ultravioleta. 


\subsection{Relacionamento serológico}

Estudos para a determinação das relações serológicas do potyvírus causador do mosqueado com o PWV, ZYMV e PRSV-W foram feitos através do teste serológico de ELISA ("Enzyme Linked Immunosorbent Assay"), do tipo PTA ("Plate Trapped Antigen"), com algumas modificações da forma descrita por Mowat \& Dawson (1987). Foram utilizados os antissoros contra o potyvírus do mosqueado do maracujazeiro produzido neste trabalho e aqueles contra 0 PWV, o ZYMV e o PRSV-W, disponíveis no Laboratório de Virologia Vegetal da ESALQ/USP.

Os antissoros contra o potyvírus do mosqueado e do PWV foram préadsorvidos com extrato de folhas de maracujazeiro sadio antes da utilização no teste serológico. Para isso, extratos de plantas sadias de maracujazeiro, diluídos na proporção de 1:10 em tampão Tris- $\mathrm{HCl}(0,2 \mathrm{M}$ Tris- $\mathrm{HCl}, 0,15 \mathrm{M}$ $\mathrm{NaCl}, \mathrm{pH} 7,2$ ), foram misturados, na proporção de 1:1, com os respectivos antissoros, diluídos 1:500 no mesmo tampão, separadamente. Estas misturas foram incubadas a $4^{\circ} \mathrm{C}$ por 12 horas, sendo posteriormente centrifugadas a $5.000 \mathrm{rpm}$ por 10 minutos. O sobrenadante foi utilizado diretamente para o teste serológico de PTA-ELISA.

\subsection{PTA-ELISA}

Amostras individuais de tecido vegetal foram maceradas em almofariz na presença de tampão carbonato $\left(0,015 \mathrm{M} \mathrm{Na}_{2} \mathrm{CO}_{3}, 0,035 \mathrm{M} \mathrm{NaHCO}_{3}, \mathrm{pH}\right.$ 9,6), na diluição de 1:20, sendo então colocados $100 \mu \mathrm{L}$ destas amostras, por pocinho, em uma placa de ELISA, usando o mínimo de 2 pocinhos por amostra. Amostras de plantas infectadas com cada um dos vírus testados, denominadas controles positivos, e amostras de plantas sadias, controles negativos, foram utilizadas em cada teste. As amostras foram incubadas por 1,5 hora a $37^{\circ} \mathrm{C}$, seguida de 3 lavagens consecutivas com PBS-Tween $\left(0,0015 \mathrm{M} \mathrm{KH}_{2} \mathrm{PO}_{4}, 0,14\right.$ 
$\mathrm{M} \mathrm{NaCl}, 0,004 \mathrm{M} \mathrm{Na}_{2} \mathrm{HPO}_{4}, 0,003 \mathrm{M} \mathrm{KCl}, \mathrm{pH}$ 7,4 + 0,5 mL Tween 20/L). Posteriormente, adicionaram-se $100 \mu \mathrm{L}$ de antissoro específico diluído 1:1.000 em tampão Tris- $\mathrm{HCl}$, (0,2 M Tris- $\mathrm{HCl}, 0,15 \mathrm{M} \mathrm{NaCl}, \mathrm{pH} 7,2)$. Novamente, a placa de ELISA foi incubada por 1,5 hora a $37^{\circ} \mathrm{C}$ e lavada com PBS-Tween 3 vezes consecutivas. Posteriormente, $100 \mu \mathrm{L}$ de imunoglobulina $\mathrm{G}$ ( $(\mathrm{gG})$ conjugada com fosfatase alcalina (SIGMA A-8025), diluída 1:32.000 em tampão Tris- $\mathrm{HCl}, \mathrm{pH} 7,2$ foram adicionados em cada pocinho, promovendo-se a incubação e as lavagens como detalhadas para as fases anteriores. Decorrido o período de $1,5 \mathrm{~h}$ foram colocados $100 \mu \mathrm{L}$ do substrato $\tilde{n}$-fosfato de nitrofenil (SIGMA N-9389), diluído em dietanolamina $(0,6 \mathrm{mg} / \mathrm{mL})$, em cada pocinho. $\mathrm{O}$ substrato foi incubando à temperatura ambiente, no escuro, por 30 a 60 minutos. A reação foi avaliada medindo-se a absorbância a $405 \mathrm{~nm}$ em leitor de ELISA da marca Metertech $\Sigma 960$. Uma amostra foi considerada positiva quando seu valor de absorbância foi superior a 3 vezes o valor de absorbância de extratos de plantas sabidamente sadias.

\subsection{Teste de proteção entre isolados do potyvirus causador de mosqueado e do PWV}

Foram realizados testes de proteção com a finalidade de avaliar a homologia entre as estirpes do vírus causador de mosqueado e do PWV, visto que a proteção é um indicador da identidade de estirpes de espécies da família Potyviridae (Van Regenmortel et al., 2000).

A proteção entre os isolados PWV-1 e PWV-2 e os isolados M1, M2 e M3 do potyvírus causador de mosqueado foi estudada em plantas de maracujazeiro amarelo e de crotalária (Crotalaria juncea), separadamente. Essa escolha foi efetuada com base nos resultados obtidos por Novaes (2002) que evidenciou o efeito da espécie vegetal na proteção entre estirpes do PWV.

Dois testes de proteção, independentes, foram realizados em casa de vegetação. No primeiro, 24 plantas de maracujazeiro amarelo e 24 plantas de 
crotalária foram, previamente, inoculadas mecanicamente com o isolado PWV1. Dez dias após a inoculação comprovourse a infecção das plantas por PTAELISA. Em seguida as plantas foram superinoculadas, também mecanicamente, com os isolados $M 1, M 2$, e $M 3$ separadamente. A superinoculação, ou inoculação de desafio, consiste da inoculação realizada em plantas já infectadas por uma estirpe de vírus. Cada isolado foi superinoculado em 8 plantas de maracujazeiro e 8 plantas de crotalária. Por ocasião do desafio, cada isolado foi inoculado mecanicamente em duas plantas sadias de crotalária e duas de maracujazeiro, para se avaliar a infectividade do inóculo empregado na superinoculação, através da posterior observação de sintomas. Após 7, 14 e 21 dias da superinoculação, extratos foliares obtidos da região do ponteiro das plantas desafiadas de maracujazeiro foram inoculados em plantas de abobrinha-de-moita 'Caserta' sadias, na tentativa de se recuperar os isolados desafiantes. No caso das plantas de crotalária desafiadas, tentativas de recuperação dos isolados desafiantes foram efetuadas também no $35^{\circ}$ dia após a superinoculação. A ausência de recuperação do isolado usado na superinoculação é um indicativo da proteção oferecida pelo primeiro isolado inoculado.

No segundo experimento foram empregadas 18 plantas de maracujazeiro amarelo e 18 de crotalária previamente infectadas com o isolado PWV-2, procedendo-se da mesma maneira que no experimento anterior. A superinoculação com os isolados M1, M2 e M3 foi feita em seis plantas de crotalária e seis plantas de maracujazeiro, separadamente com cada um dos isolados. 


\subsection{Efeito do potyvírus causador do mosqueado no desenvolvimento das plantas de maracujazeiro em casa-de-vegetação}

Foram efetuados dois experimentos distintos para a determinação do efeito do potyvírus causador do mosqueado no desenvolvimento das plantas de maracujazeiro, comparando-o com os efeitos causados pelo PWV, em casa-devegetação. O primeiro experimento foi efetuado no período de novembro de 2001 a janeiro de 2002 e o segundo de junho de 2002 a agosto de 2002. Ambos os experimentos seguiram o procedimento abaixo detalhado.

Mudas de maracujazeiro amarelo, com 4 folhas definitivas completamente expandidas, foram mecanicamente inoculadas com os isolados M1, M2, e M3 do potyvírus causador de mosqueado e os isolados PWV-1 e PWV-2. Cada um dos isolados foi inoculado separadamente em 10 plantas. $O$ mesmo número de plantas foi inoculado apenas com o tampão para servir de testemunha. As plantas representativas dos diferentes tratamentos foram dispostas ao acaso em casa-de-vegetação. A comprovação de infecção foi efetuada após 10 dias da inoculação através de uma avaliação visual de sintomas e de teste serológico de PTA-ELISA.

Trinta e cinco dias após a inoculação foram efetuadas avaliações de altura, área foliar e peso fresco e seco da parte aérea e do sistema radicular. Para a determinação da altura das plantas foi empregada um fita métrica graduada em centímetros. No caso da determinação da área foliar utilizou-se um medidor de área foliar portátil (Li-Cor L1-3000 A). Tanto para a determinação do peso fresco como seco da parte aérea e do sistema radicular foi utilizada uma balança semi-analítica. Os pesos frescos foram obtidos diretamente após o desenvasamento das plantas, retirada de solo e a separação da parte aérea do sistema radicular. Os pesos secos das mesmas partes foram obtidos após secagem em saco de papel, quando pesagens sucessivas indicaram peso constante. 


\subsection{Caracterização molecular do gene da capa protéica do potyvírus causador do mosqueado em maracujazeiro}

\subsubsection{Extração de RNA total}

Para a extração do RNA total foi empregada a metodologia descrita por Gibbs \& Mackenzie (1997). Cinqüenta a cem miligramas de tecido foliar, coletados de maracujazeiros infectados com os isolados M2 e M3, separadamente, foram macerados em nitrogênio líquido e colocados em microtubos de $2 \mathrm{~mL}$. Foram adicionados $500 \mu \mathrm{L}$ de tampão para lavagem (10 $\mathrm{mM}$ Tris- $\mathrm{HCl} \mathrm{pH}$ 8,0, 1mM EDTA pH 8,0, $2 \mathrm{M} \mathrm{NaCl}, 0,05 \%$ BSA). Promoveu-se a homogenização desta mistura e posterior centrifugação a $14.000 \mathrm{rpm}$ por 8 minutos. Ao material precipitado foram adicionados $600 \mu \mathrm{L}$ de CTAB [2\% CTAB (brometo de hexadeciltrimetilamônio), 1,4 M NaCl, 0,1 M Tris-HCl pH 8,0, 0,5\% mercaptoethanol]. Essa mistura foi agitada vigorosamente e incubada a $55^{\circ} \mathrm{C}$ por 20 minutos. Foram adicionados $400 \mu \mathrm{L}$ de clorofórmio: álcool isoamílico (24:1) e promoveu-se a centrifugação da mistura a $14.000 \mathrm{rpm}$ por 10 minutos. A fase aquosa superior foi retirada e transferida para um novo microtubo de 2 $\mathrm{mL}$. Após determinação do volume da fase aquosa, adicionou-se 1/10 de volume de acetato de sódio $7,5 \mathrm{M}$ e 1 volume de isopropanol mantendo a mistura a $-20^{\circ} \mathrm{C}$ por 20 minutos para precipitação do RNA. Após este período a suspensão foi centrifugada a $14.000 \mathrm{rpm}$ por 8 minutos e adicionou-se ao precipitado obtido $1 \mathrm{~mL}$ de etanol $70 \%$ gelado. Promoveu-se nova centrifugação a $14.000 \mathrm{rpm}$ por 1 minuto e o precipitado foi dissolvido em $30 \mu \mathrm{l}$ de água Milli $Q$, tratada com dietil pirocarbonato (DEPC).

\subsubsection{RT-PCR}

A primeira fita de DNA complementar (CDNA) foi sintetizada a partir do RNA total extraído das plantas de maracujazeiro amarelo infectadas com os 
isolados M2 e M3, separadamente. Dois e meio $\mu \mathrm{L}$ de suspensão de RNA total foram misturados a 10 pmoles do primer PV1 [5'GATTTAGGTGACACTATAG(T) $\left.{ }_{17}(\mathrm{~A} / \mathrm{G} / \mathrm{C})\right)^{\prime}$ ] (Gibbs \& Mackenzie, 1997), que se anela na cauda poli-A, presente no terminal 3' do RNA das espécies do gênero Potyvirus (Figura 4). Adicionaram-se ainda a esta mistura 1,0 $\mu \mathrm{L}$ de mistura de dNTP'S (dATP, dGTP, dCTP e dTTP) 10 Mm e 8,5 $\mu \mathrm{L}$ água MilliQ. A mistura acima descrita foi mantida a $65^{\circ} \mathrm{C}$ por 5 minutos e posteriormente em gelo por 2 minutos. Em seguida foram adicionados $4 \mu$ de tampão $5 X$ da enzima transcriptase reversa (Tris-HCl 250 mM, pH 8,3, KCl 375 mM, MgCl 15 $\mathrm{mM}), 2 \mu \mathrm{L}$ de DTT (ditiotreitol) e 20 unidades de RNAsin Ribonuclease Inhibitor (Promega). Essa mistura permaneceu a $42^{\circ} \mathrm{C}$ por 2 minutos. Finalmente, adicionaram-se 200 unidades de enzima Superscript Transcriptase Reversa (Invitrogen). Essa solução foi incubada por 60 minutos a $42^{\circ} \mathrm{C}$ e posteriormente aquecida a $70^{\circ} \mathrm{C}$ por 5 minutos para a degradação da enzima.

O cDNA foi em seguida usado em reação de PCR ("polymerase chain reaction"). Para isso, 2,5 $\mu \mathrm{L}$ do produto da reação com a enzima transcriptase reversa foram misturados a 2,5 $\mu \mathrm{L}$ de tampão 10X de PCR (Tris-SO $600 \mathrm{mM}$, pH 8,9, sulfato de amônio $180 \mathrm{mM}$ ), 0,9 $\mu \mathrm{L}$ de $\mathrm{MgSO}_{4} 50 \mathrm{mM}, 10$ pmoles do primer PV1, 10 pmoles do primer 2 (PV2) [5'TAATACGACTCACTATAGGGIAA(C/T)AA(C/T)AG(C/T)GGICA(A/G)C C-3'] (Gibbs \& Mackenzie, 1997), que se anela em uma região conservada do gene responsável pela inclusão nuclear $\mathrm{b}(\mathrm{Nlb})$ de espécies do gênero Potyvirus (Figura 4), 0,5 $\mu \mathrm{L}$ dNTP's 10 mM, 2,5 unidades de Taq DNA Polymerase (Promega), completando, com água MilliQ, $25 \mu \mathrm{L}$. O regime empregado no termociclador (MJ Research PTC 200) foi de 94ํㅡ por 2 minutos, seguido de 35 ciclos de 6 minutos, divididos em 1 minuto a 94으, 2 minutos a $52^{\circ} \mathrm{C}$ e 3 minutos a $72^{\circ} \mathrm{C}$, finalizando com $72^{\circ} \mathrm{C}$ por 10 minutos. Para comprovação da amplificação, $2 \mu \mathrm{L}$ do produto de PCR foram submetidos a eletroforese em gel 
de agarose a $1 \%$ contendo $0,5 \mu \mathrm{g} / \mathrm{mL}$ de brometo de etídeo. A visualização do gel de agarose foi efetuada sob luz ultravioleta.

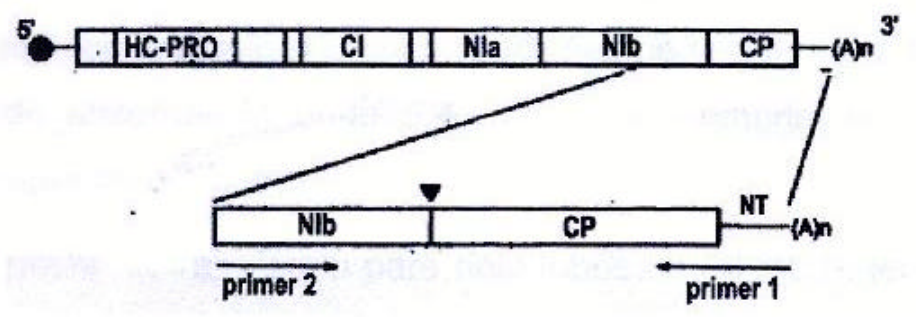

Figura 4 - Representação esquemática do genoma do gênero Potyvirus, enfatizando a localização da região de anelamento dos primers PV1 e PV2. $(A)_{n}$, cauda poli-A; NT, terminal 3' não traduzido; $C P$, capa protéica; Nib, inclusão nuclear b

\subsubsection{Ligação ao plasmídeo vetor}

O cDNA produzido no RT-PCR foi ligado ao plasmídeo vetor pGem ${ }^{\circledR}$ pelo uso do kit pGem® T Easy Vector System (Promega). Foram utilizados para a reação de ligação $4 \mu \mathrm{L}$ da solução contendo cDNA, $4 \mu \mathrm{L}$ de tampão $2 \mathrm{X}$ de ligação rápida (Tris-HCl 60 mM, pH 7,8; $\mathrm{MgCl}_{2} 20$ mM, DTT 20 mM, ATP 2 mM, $10 \% \mathrm{PEG}), 1 \mu \mathrm{L}$ do vetor $\mathrm{pGem} \circledast-\mathrm{T}, 1 \mu \mathrm{L}$ da enzima $\mathrm{T}_{4}$ DNA ligase. A mistura, com volume final de $12 \mu \mathrm{L}$, foi incubada a temperatura ambiente por 2 horas e então armazenada $\mathrm{a}-20^{\circ} \mathrm{C}$. 


\subsubsection{Preparo de células competentes de Escherichia coli para transformação}

Células competentes foram preparadas a partir de uma colônia isolada de Escherichia coli da linhagem DH5á. Inicialmente foi inoculada uma colônia bacteriana em $15 \mathrm{~mL}$ de meio LB (2,0 g triptona, $1,0 \mathrm{~g}$ de extrato de levedura, 2,0 $\mathrm{g}$ de $\mathrm{NaCl}, 3,5 \mathrm{~g}$ de bacto Agar, $\mathrm{pH}$ 7,0, em volume final de $200 \mathrm{~mL}$ ) e incubada a $37^{\circ} \mathrm{C}$, sob rotação constante de $220 \mathrm{rpm}$. Cem microlitros desta suspensão foram transferidos para $4 \mathrm{~mL}$ de meio LB. Essa cultura foi incubada sob as mesmas condições de temperatura e rotação até atingir valor de absorbância entre 0,4 e 0,48, no comprimento de onda de $600 \mathrm{~nm}$, em espectrofotômetro.

Quando atingida a absorbância acima citada, os tubos contendo as suspensões foram colocados em gelo por 15 minutos e posteriormente o volume foi transferido para microtubos de $1,5 \mathrm{~mL}$ previamente gelados. Promoveu-se posteriormente uma centrifugaçãp a $5.000 \mathrm{rpm}$, por 5 minutos, a $4^{\circ} \mathrm{C}$. O precipitado obtido foi diluído lentamente em 100 ì $\mathrm{L}$ de $0,1 \mathrm{M} \mathrm{MgCl}_{2} \mathrm{e}$ posteriormente centrifugado, a $5.000 \mathrm{rpm}$, por 5 segundos, a $4^{\circ} \mathrm{C}$. O precipitado obtido foi vagarosamente ressuspendido em 100 i $\mathrm{L}$ de $0,1 \mathrm{M} \mathrm{CaCl}_{2}$ e incubado em gelo por 30 minutos. Promoveu-se a centrifugação da suspensão a 5.000 rpm, por 5 segundos, a $4^{\circ} \mathrm{C}$ e descartou-se o sobrenadante. $\mathrm{O}$ precipitado foi dissolvido em 100 ì $\mathrm{L}$ de tampão de estocagem $\left(8,6 \mathrm{~mL} \mathrm{0,1} \mathrm{M} \mathrm{CaCl}_{2}, 1,4 \mathrm{~mL}\right.$ glicerol) e armazenado a $-80^{\circ} \mathrm{C}$.

\subsubsection{Transformação de E. coli com plasmídeo vetor recombinante}

A transformação das células competentes foi efetuada de acordo com protocolo descrito por Sambrook et al. (1989). Cem microlitros de células competentes foram misturados com 2 a $4 \mu \mathrm{L}$ do produto de ligação em microtubos de 1,5 mL. Essa mistura foi mantida em gelo por 30 minutos sendo 
então acondicionada a $42^{\circ} \mathrm{C}$ por 1,5 minutos e retornada ao gelo onde permaneceu por 1 minuto. Após este choque térmico, os tubos receberam, em ambiente asséptico, $400 \mu \mathrm{L}$ de meio SOC $(2,0 \mathrm{~g}$ triptona, $0,5 \mathrm{~g}$ de estrato de levedura, 0,05 $\mathrm{g}$ de $\mathrm{NaCl}, 0,5 \mathrm{~mL}$ de $\mathrm{MgCl}_{2} 2 \mathrm{M}, 2,9 \mathrm{~mL}$ de glicose $1 \mathrm{M}$, em volume final de $100 \mathrm{~mL}$ de solução). A mistura permaneceu a $37^{\circ} \mathrm{C}$ por 1,5 horas. Em seguida, foi centrifugada a 3.000 rpm, por 1 minuto, para concentração das células bacterianas. Foram descartados $200 \mu \mathrm{L}$ do sobrenadante, sendo o volume restante plaqueado em placas de Petri contendo meio LB acrescido de ampicilina $100 \mu \mathrm{g} / \mathrm{mL}$, IPTG $100 \mathrm{mg} / \mathrm{mL}$ e XGal 50 $\mathrm{mg} / \mathrm{mL}$, para a avaliação da atividade de $\beta$-galactosidase nos transformantes e seleção destes. As placas foram incubadas a $37^{\circ} \mathrm{C}$ por 14 horas.

As colônias bacterianas de cor branca foram consideradas portadoras de plasmídeos recombinantes sendo individualmente inoculadas em $3 \mathrm{~mL}$ de meio LB, acrescido de ampicilina $100 \mathrm{mg} / \mathrm{mL}$. Os meios inoculados com as colônias brancas separadamente foram incubados por 14 horas a $37^{\circ} \mathrm{C}$ sob rotação de $220 \mathrm{rpm}$.

No caso da necessidade de conservação de clones obtidos, cerca de $100 \mu \mathrm{L}$ de meio inoculado após a incubação foram misturados com $100 \mu \mathrm{L}$ de glicerol $50 \%$ e esta mistura foi armazenada a $-80^{\circ} \mathrm{C}$.

\subsubsection{Extração de DNA plasmidial}

Para a extração de plasmídeos foi empregada a metodologia descrita por Hoisington et al. (1994) com algumas modificações. As culturas bacterianas desenvolvidas em LB foram transferidas para microtubos de $1,5 \mathrm{~mL}$ e centrifugadas a 14.000 rpm por 5 minutos. O precipitado obtido foi ressuspendido em $100 \mu \mathrm{L}$ de solução I (50 mM glicose, 10 mM EDTA, 25 mM Tris, pH 8,0) gelada e deixado, por 20 minutos, à temperatura ambiente. Após a incubação adicionaram-se $200 \mu \mathrm{L}$ de solução II (75 mL água estéril, $20 \mathrm{~mL} \mathrm{NaOH} 1$ M, 5 $\mathrm{mL}$ SDS 20\%) a temperatura ambiente. Homogenizou-se a mistura 
cuidadosamente e manteve-se a mesma em gelo por 10 minutos. A mistura foi centrifugada a 13.000 rpm por 15 minutos. Adicionaram-se $150 \mu \mathrm{L}$ de solução III ( 24,6 g acetato de sódio, pH 4,8, ajustado com ácido acético glacial, em volume final de $10 \mathrm{~mL}$ ) gelada, que foi delicadamente misturada e centrifugada a $13.000 \mathrm{rpm}$, por 15 minutos. O sobrenadante foi removido para um novo microtubo de $1,5 \mathrm{~mL}$ e a ele se adicionaram $400 \mu \mathrm{L}$ de clorofórmio gelado saturado com acetato de sódio. Após agitação vigorosa a mistura foi centrifugada a $13.000 \mathrm{rpm}$, por 5 minutos. O sobrenadante foi transferido para um novo microtubo de $1,5 \mathrm{~mL}$ contendo $400 \mu \mathrm{L}$ de fenol equilibrado com Tris 10 $\mathrm{mM}, \mathrm{pH}$ 8,0. Depois de agitada vigorosamente a mistura foi novamente centrifugada a 13.000 rpm por 5 minutos. A fase aquosa foi removida para um novo microtubo de $1,5 \mathrm{~mL}$ contendo $1 \mathrm{~mL}$ de etanol absoluto, mantido a $-20^{\circ} \mathrm{C}$. Homogenizou-se a mistura vagarosamente e promoveu-se a incubação por 10 minutos a $-20^{\circ} \mathrm{C}$. Novamente a mistura foi centrifugada a $13.000 \mathrm{rpm}$, por 10 minutos, sendo descartado o sobrenadante. A secagem do precipitado foi feita invertendo-se os microtubos abertos sobre a bancada e mantendo-os a temperatura ambiente. O precipitado foi dissolvido em 20-40 $\mu \mathrm{L}$ de água MilliQ. A suspensão foi tratada com 2,2 $\mu \mathrm{L}$ de RNAse $(10 \mathrm{mg} / \mathrm{mL}$ ) (Pharmacia) e incubada a $37^{\circ} \mathrm{C}$ por 2 horas. Posteriormente o material foi armazenado a $-20^{\circ} \mathrm{C}$.

Para determinação da concentração de DNA plasmidial, o material extraído foi submetido a eletroforese em gel de agarose $1 \%$ na presença de um padrão com concentração conhecida do pGem (Promega). Em função da intensidade da banda observada no gel de agarose foi estimada a concentração de DNA. 


\subsubsection{Sequenciamento}

O sequenciamento foi feito no laboratório de Genética Molecular do Setor de Fitopatologia do Departamento de Entomologia, Fitopatologia e Zoologia Agrícola, Setor de Fitopatologia, da ESALQ/USP.

O DNA plasmidial foi amplificado utilizando o kit Dyenamic ${ }^{T M}$ ET Terminator Cycle Sequencing (Amersham Pharmacia Biotech), contendo os primers M13 "forward" e M13 "reverse". Na reação de amplificação utilizaram-se 3,2 pmol de primer M13, 2,0 $\mu \mathrm{L}$ de Dyenamic e 400-500 ng de DNA em um volume final, completado com água milliQ, de $10 \mu \mathrm{L}$. O regime do termociclador foi de 30 ciclos, sendo cada um de 20 segundos a $95^{\circ} \mathrm{C}, 15$ segundos a $50^{\circ} \mathrm{C}$ e 1 minuto a $60^{\circ} \mathrm{C}$. Para finalizar utilizourse a temperatura de $4^{\circ} \mathrm{C}$ por 5 minutos. Após a amplificação, promoveu-se a precipitação do material adicionando-se 1 $\mathrm{mL}$ de acetato de sódio/EDTA $\left(\mathrm{NaC}_{2} \mathrm{H}_{3} \mathrm{O}_{2} 1,5 \mathrm{M}\right.$, pH 8,0, EDTA $\left.250 \mathrm{mM}\right)$ e 40 $\mu \mathrm{L}$ de etanol $95 \%$. A mistura foi colocada em gelo e permaneceu no escuro por 18 minutos. Após este período a mesma foi centrifugada a $13.000 \mathrm{rpm}$, por 15 minutos, a $4^{\circ} \mathrm{C}$. O sobrenadante foi descartado e o precipitado dissolvido em $250 \mu \mathrm{L}$ de etanol $70 \%$. Promoveurse uma centrifugação a $13.000 \mathrm{rpm}$, por 5 minutos, descartando-se, novamente, o sobrenadante. O precipitado foi seco no termociclador a $90^{\circ} \mathrm{C}$ por 1 minuto sendo posteriormente dissolvido em $3 \mu \mathrm{L}$ de tampão de carregamento (formamida). A mistura foi homogenizada em vortex por 15 segundos, promovida uma rápida centrifugação, e posteriormente foi retirada uma alíquota de $1,5 \mu \mathrm{L}$ para ser levada ao aparelho para seqüenciar.

\subsection{Análise dos resultados}

A análise estatística dos dados referentes ao efeito do potyvírus causador do mosqueado no desenvolvimento das plantas de maracujazeiro e a comparação com os efeitos causados pelo PWV foi efetuada utilizando-se o 
programa Statistical Analysis System V. 6.08 (SAS Institute, 1993), sendo a significância obtida avaliada aplicando-se o teste de Tukey $5 \%$ (Gomes, 1990).

As seqüências consenso dos produtos amplificados do gene da capa protéica do vírus causador de mosqueado em maracujazeiro foram obtidas alinhando-se nucleotídeos pelo programa CLUSTAL L. Os consensos obtidos foram comparados com as seqüências de dois isolados do PWV (PWV F-101 e PWV-SP) obtidas por Novaes (2002), alinhadas pelo programa Multalin (http:/prodes.Toulouse.inra.fr/multalin /multalin.html) e a seqüência de aminoácidos deduzidos da proteína do capsídeo pelo programa Translate (http:://ca.expasy.org/tools/dna.html). A comparação da identidade entre os isolados do potyvírus do mosqueado e dos isolados do PWV foram efetuadas pelo programa NCBI Blast (Basic Local Alignment Search Tool) disponível no endereço http://blast@ncbi.nlm.nih.gov. A localização do gene da capa protéica (CP) bem como a região não traduzida (NT) e parte da região Nlb foi feita alinhando-se as seqüências com a do genoma completo do Cowpea aphidborne mosaic vírus (CABMV), depositada no banco de dados do NCBI com código de acesso AF348210 (Mlotshwa et al., 2002).

As seqüências de nucleotídeos dos isolados do potyvírus do mosqueado do maracujazeiro foram comparadas com as seqüências de outros potyvírus obtidos no NCBI: CABMV (AF348210), PRSV-W (AY027810), ZYMV (NC 003224), Soybean mosaic vírus- SMV (X96665), Watermelon mosaic vírus type-2- WMV-2 (AF322376), PWV oriundo de Taiwan- PWV-T (AF208662), PWV oriundo do Japão PWV-J (D85949) e PWV oriundo da Austrália- PWV-A (AJ430527). A identidade entre os isolados foi obtida com o auxílio do programa CLUSTAL W (1.82).

Um dendrograma foi obtido através do programa MEGA (www.megasoltware.net), usando o método de agrupamento de vizinhos ('neighbor-joining'- NJ). A análise do teste de confiança da topologia ('bootstrap') consistiu de 2000 réplicas. 


\section{RESULTADOS}

\subsection{Microscopia eletrônica}

Com o exame de tecidos foliares de amostras de abobrinha-de-moita e de maracujazeiro sintomáticos foi possível observar correlação entre a expressão de sintomas nas plantas infectadas e a presença de inclusões do tipo cata-vento, típicas do gênero Potyvirus (Figura 5). Dificuldades foram encontradas para a observação de inclusões e/ou partículas virais em cortes ultrafinos de tecido de abobrinha-de-moita cv. Caserta infectada com o potyvírus causador de mosqueado em maracujazeiro. O mesmo não ocorreu no exame de tecidos de maracujazeiros infectados.

\subsection{Purificação do potyvírus causador de mosqueado em maracujazeiro e produção de antissoro}

A purificação feita a partir de folhas de plantas de maracujazeiro sistemicamente infectadas com o potyvírus causador de mosqueado permitiu a obtenção de um purificado com a concentração de $6,36 \mu \mathrm{g}$ de úrus/ $\mu \mathrm{L}$. A observação do purificado viral, em microscopia eletrônica de transmissão, revelou a presença de partículas flexuosas, alongadas e íntegras (Figura 6) semelhantes æ̀̀ do gênero Potyvirus e idênticas àquelas observadas em "leaf dip" de extratos de plantas de abobrinha-de-moita cv. Caserta exibindo amarelecimento de nervuras, que foram inoculadas com extratos de folhas de 


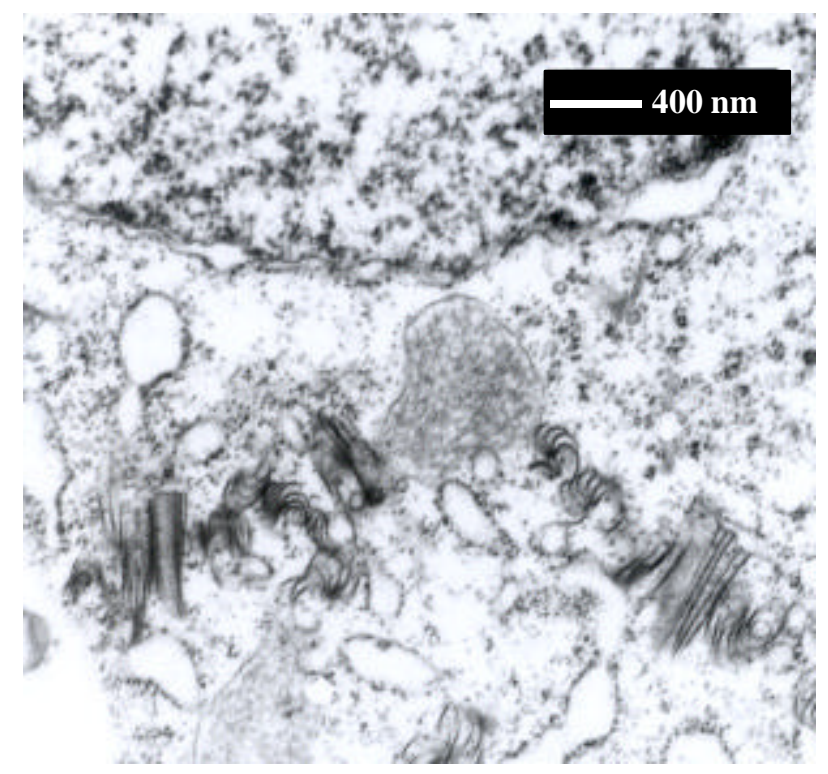

Figura 5 - Micrografia eletrônica de secção de folha de abobrinha-de-moita cv. Caserta, infectada com o potyvírus do mosqueado e exibindo sintomas de amarelecimento de nervuras, aonde podem ser observas inclusões do tipo cata-vento, típicas de vírus do gênero Potyvirus

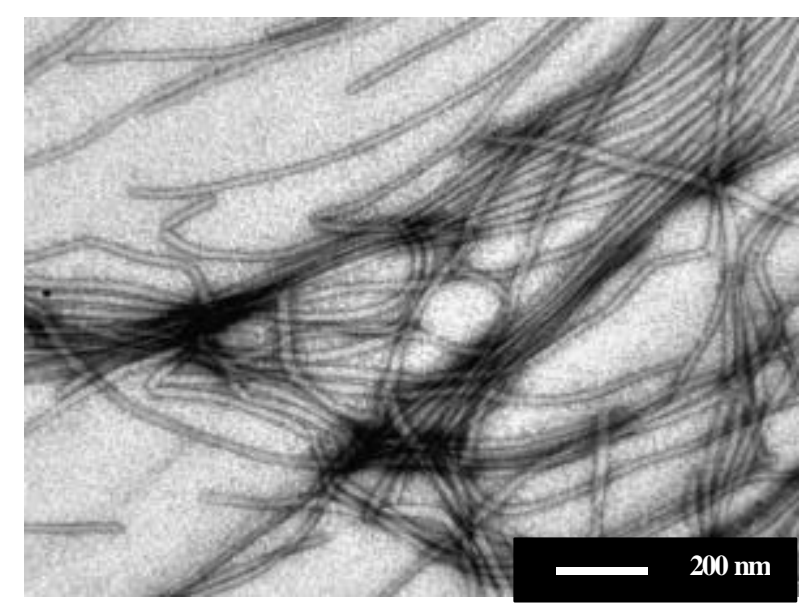

Figura 6 - Observação, em microscopia eletrônica de transmissão, do purificado do potyvírus causador de mosqueado em maracujazeiro 
maracujazeiro apresentando sintoma de mosqueado foliar (Figura 2).

O antissoro policlonal obtido contra o potyvírus do mosqueado do maracujazeiro foi analisado através de PTA-ELISA, em diferentes diluições. O antissoro bruto foi inicialmente pré-adsorvido com extrato de folhas sadias de maracujazeiro. O resultado de um teste de PTA-ELISA utilizando-se 4 diluições de tecido de maracujazeiro infectado e 4 diluições do antissoro pré-adsorvido está na tabela 1. A melhor diluição encontrada para o antissoro foi de 1:1000, que detectou o potyvírus em extratos diluídos até 1:20. A diluição 1:2000 não permitiu a detecção desse potyvírus em diferentes diluições do extrato vegetal, de acordo com os critérios estabelecidos para o teste.

\subsection{Gama de hospedeiras do potyvírus causador de mosqueado em maracujazeiro}

A relação de espécies infectadas e não infectadas, via inoculação mecânica, com os três isolados do potyvírus causador de mosqueado em maracujazeiro (M1, M2 e M3) encontra-se na tabela 2. Os dois isolados do PWV (PWV-1 e PWV-2) também foram inoculados paralelamente para fins de comparação.

Observou-se certo paralelismo na reação das espécies inoculadas com os isolados do potyvírus causador de mosqueado em maracujazeiro e do PWV. Com base nas avaliações visuais de sintoma e serológicas de PTAELISA e/ou 'Western blot', constatou-se que todas as espécies infectadas pelos isolados do PWV foram também infectadas pelos isolados M1, M2 e M3. Além dessas, o potyvírus causador de mosqueado em maracujazeiro também infectou C. pepo cv. Caserta e abóbora híbrida Tetsukabuto (C. maxima Dunch. Ex Lam X C. moschata 'Takayama'), que não foram infectadas pelo PWV. 
Tabela 1. Valores de absorbância $\left(A_{450}\right)$ em teste de PTA-ELISA utilizando 4 diluições do antissoro* contra o potyvírus do mosqueado e 5 diluições de extrato foliar de maracujazeiro amarelo $(P$. edulis $\mathrm{f}$, flavicarpa) sadio e infectado

\begin{tabular}{cccccc}
\hline \multirow{2}{*}{ Amostra } & Diluição do & \multicolumn{4}{c}{ Diluição do antissoro } \\
& extrato foliar & $1: 250$ & $1: 500$ & $1: 1000$ & $1: 2000$ \\
\hline Maracujazeiro & $1: 1,25$ & 0,800 & 0,635 & 0,498 & 0,262 \\
infectado & $1: 2,5$ & 0,832 & 0,598 & 0,481 & 0,258 \\
& $1: 5$ & 0,761 & 0,589 & 0,491 & 0,238 \\
& $1: 10$ & 0,702 & 0,531 & 0,406 & 0,211 \\
Maracujazeiro & $1: 20$ & 0,604 & 0,500 & 0,399 & 0,198 \\
sadio & $1: 1,25$ & 0,102 & 0,100 & 0,100 & 0,098 \\
& $1: 2,5$ & 0,101 & 0,103 & 0,101 & 0,098 \\
& $1: 5$ & 0,095 & 0,091 & 0,098 & 0,087 \\
& $1: 10$ & 0,087 & 0,087 & 0,092 & 0,090 \\
& $1: 20$ & 0,087 & 0,090 & 0,093 & 0,088 \\
\hline
\end{tabular}

* antissoro pré-adsorvido com extrato de folhas sadias de maracujazeiro 
Tabela 2. Reação de diferentes espécies vegetais inoculadas mecanicamente com três isolados do potyvírus causador de mosqueado em maracujazeiro (M1, M2 e M3) e com dois isolados do PWV (PWV-1 e PWV-2)

\begin{tabular}{|c|c|c|c|c|c|c|}
\hline \multicolumn{2}{|c|}{ Plantas-teste } & \multicolumn{5}{|c|}{ Isolados } \\
\hline Família & Espécies & M1 & M2 & M3 & PWV-1 & PWV-2 \\
\hline & \multicolumn{6}{|c|}{ Aizoaceae } \\
\hline \multicolumn{7}{|c|}{ Amaranthaceae } \\
\hline & Gomphrena globosa & - , As &,- As &,- As &,- As &,- As \\
\hline \multicolumn{7}{|c|}{ Chenopodiaceae } \\
\hline & $\begin{array}{l}\text { Chenopodium } \\
\text { amaranticolor }\end{array}$ &,+ LLN &,+ LLN &,+ LLN &,+ LLN &,+ LLN \\
\hline & C. murale & - , As & - , As &,- As & - , As & - , As \\
\hline & C. quinoa &,+ LLC &,+ LLC &,+ LLC & + , LLC &,+ LLC \\
\hline \multicolumn{7}{|l|}{ Compositae } \\
\hline & Helianthus annuus & - , As &,- As &,- As &,- As &,- As \\
\hline \multicolumn{7}{|c|}{ Cucurbitaceae } \\
\hline & $\begin{array}{l}\text { Citrullus lanatus cv. } \\
\text { Crimson Sweet }\end{array}$ & - , As &,- As &,- As &,- As & - , As \\
\hline & Cucumis anguria & - , As &,- As &,- As &,- As &,- As \\
\hline & C. metuliferus &,- As &,- As &,- As &,- As &,- As \\
\hline & C. sativus & - , As & - , As &,- As & - , As & - As \\
\hline & $\begin{array}{c}\text { Cucurbita maxima cv. } \\
\text { Alice }\end{array}$ & -, As &,- As &,- As & -, As &,- As \\
\hline & $\begin{array}{c}\text { Tetsukabuto (C. } \\
\text { maxima } X C . \\
\text { moschata) }\end{array}$ &,$+ \mathrm{PC}$ &,$+ P C$ &,$+ \mathrm{PC}$ &,- As &,- As \\
\hline & $\begin{array}{l}\text { C. moschatacv. } \\
\text { Menina Brasileira }\end{array}$ & -, As & -, As &,- As & -, As & - , As \\
\hline
\end{tabular}


Tabela 2. Reação de diferentes espécies vegetais inoculadas mecanicamente com três isolados do potyvírus causador de mosqueado em maracujazeiro (M1, M2 e M3) e com dois isolados do PWV (PWV-1 e PWV-2)

\begin{tabular}{|c|c|c|c|c|c|c|}
\hline \multicolumn{2}{|c|}{ Plantas-teste } & \multicolumn{5}{|c|}{ Isolados } \\
\hline Família & Espécies & M1 & M2 & M3 & PWV-1 & PWV-2 \\
\hline \multicolumn{7}{|c|}{ Cucurbitaceae } \\
\hline & $\begin{array}{c}\text { C. moschata cv. Pira } \\
\text { Moita }\end{array}$ &,- As &,- As &,- As &,- As &,- As \\
\hline & C. pepocv. Caserta &,$+ \mathrm{AN}$ &,$+ \mathrm{AN}$ &,$+ \mathrm{AN}$ & -, PCR & -, PCR \\
\hline & Sechium edule &,- As &,- As & -, As &,- As &,- As \\
\hline & Luffa cylindrica &,- As &,- As &,- As &,- As &,- As \\
\hline \multicolumn{7}{|c|}{ Leguminosae } \\
\hline & Cassia occidentalis &,$+ \mathrm{M}^{*}$ &,$+ \mathrm{M}$ &,$+ \mathrm{M}$ &,$+ M$ &,$+ \mathrm{M}$ \\
\hline & Crotalaria juncea &,$+ \mathrm{M}$ &,$+ M$ &,$+ \mathrm{M}$ &,$+ \mathrm{M}$ &,$+ \mathrm{M}$ \\
\hline & $\begin{array}{c}\text { Glycine max cv. } \\
\text { Mirador }\end{array}$ & - , As &,- As &,- As &,- As &,- As \\
\hline & $\begin{array}{c}\text { Phaseolus vulgaris cv } \\
\text { BT-2 }\end{array}$ &,$+ \mathrm{H}$ &,$+ \mathrm{H}$ &,$+ \mathrm{H}$ &,$+ \mathrm{H}$ &,$+ \mathrm{H}$ \\
\hline & P. vulgaris cv. Carioca & - , As & - , As &,- As & - , As & - , As \\
\hline & $\begin{array}{c}\text { P. vulgaris cv. Preto } \\
\text { G2 }\end{array}$ &,$+ \mathrm{H}$ &,$+ \mathrm{H}$ &,$+ \mathrm{H}$ &,$+ \mathrm{H}$ &,$+ \mathrm{H}$ \\
\hline & $\begin{array}{c}\text { Vigna unguiculata cv. } \\
\text { Gurgueia }\end{array}$ &,- As &,- As & - As & - As &,- As \\
\hline & $\begin{array}{l}\text { V. unguiculatacv. } \\
\text { Mulato }\end{array}$ &,- As &,- As &,- As & - , As &,- As \\
\hline \multicolumn{7}{|c|}{ Passifloraceae } \\
\hline & $\begin{array}{c}\text { Passiflora edulis } \mathrm{f} . \\
\text { flavicarpa }\end{array}$ &,+ Mo & + , Mo &,+ Mo & $+, \mathrm{M}, \mathrm{B}, \mathrm{DF}$ & $+, \mathrm{M}, \mathrm{B}, \mathrm{DF}$ \\
\hline
\end{tabular}


Tabela 2. Reação de diferentes espécies vegetais inoculadas mecanicamente com três isolados do potyvírus causador de mosqueado em maracujazeiro (M1, M2 e M3) e com dois isolados do PWV (PWV-1 e PWV-2)

\begin{tabular}{|c|c|c|c|c|c|c|}
\hline \multicolumn{2}{|c|}{ Plantas-teste } & \multicolumn{5}{|c|}{ Isolados } \\
\hline Família & Espécies & M1 & $\mathrm{M} 2$ & M3 & PWV-1 & PWV-2 \\
\hline \multicolumn{7}{|l|}{ Solanaceae } \\
\hline & Capsicum annum &,- As &,- As &,- As & - , As & - , As \\
\hline & Datura stramonium &,- As &,- As & - As & - , As & - , As \\
\hline & Lagenaria vulgaris &,- As &,- As &,- As & - , As & - , As \\
\hline & $\begin{array}{c}\text { Lycopersicon } \\
\text { esculentum }\end{array}$ &,- As &,- As & - As & - As & - , As \\
\hline & Nicotiana clevelandii &,- As &,- As & - , As & - , As & - , As \\
\hline & N. glutinosa &,- As &,- As &,- As & - , As & - , As \\
\hline & N. rustica &,- As &,- As &,- As & - , As & - , As \\
\hline & N. tabacum cv. Havana &,- As &,- As &,- As & - , As & - , As \\
\hline & N. tabacum cv. TNN &,- As &,- As &,- As & - , As & - , As \\
\hline & N. tabacum cv. Turkish &,- As &,- As & - , As & - , As & - , As \\
\hline & Solanum gilo &,- As & - , As &,- As & - , As & - , As \\
\hline
\end{tabular}

* (-) não detecção em teste serológico de PTA-ELISA e/ou 'Western blot'; (+) detecção em teste serológico de PTA-ELISA e/ou 'Western blot'; (As) ausência de sintomas; (LLN) lesões locais necróticas; (LLC) lesões locais cloróticas; (PC) pontuações cloróticas foliares; (AN) amarelecimento de nervuras; (PCR) pontuações cloróticas foliares com remissão de sintomas; (M) mosaico foliar; (H) hipersensibilidade; (Mo) mosqueado foliar; (B) bolhas foliares; (DF) deformações foliares

Os três isolados do potyvírus do mosqueado do maracujazeiro causaram sintomas sistêmicos de amarelecimento das nervuras em plantas de abobrinha-de-moita cv. Caserta, conforme apontado anteriormente e ilustrado 
na figura 3. Na abóbora híbrida, do tipo Tetsukabuto, esses isolados induziram sintomas de pontuações cloróticas nas folhas.

Foi observada a presença de sintomas do tipo pontuações cloróticas nas folhas de $C$. pepo cv. Caserta, quando inoculadas com os isolados PWV-1 e PWV-2, porém, houve remissão de sintomas e não se detectou o vírus nos testes serológicos de PTA-ELISA e 'Western blot'.

\subsection{Transmissão do potivírus do mosqueado}

\subsubsection{Efeito da espécie fonte de inóculo na eficiência da transmissão mecânica}

Os dados referentes aos testes de transmissão mecânica do vírus causador de mosqueado em maracujazeiro, isolado M1, para abobrinha-demoita cv. Caserta, maracujazeiro amarelo, feijão preto cv. BT-2 e Crotalaria juncea encontram-se na tabela 3.

Ao se utilizarem, como fontes de inóculo, folhas de maracujazeiro amarelo, feijão preto cv. BT-2 e C. juncea infectadas com o isolado M1, observou-se 100\% de transmissão para as diferentes espécies de plantas-teste inoculadas. Testes de PTA-ELISA de amostras oriundas destas plantas confirmaram a presença do potyvírus. O mesmo não ocorreu quando se empregou extrato de abobrinha-de-moita cv. Caserta infectada. Neste caso, observou-se que $\mathrm{o}$ isolado M1 apresentou a peculiaridade de infectar apenas plantas de 'Caserta' com 100\% de eficiência. Nenhuma planta de maracujazeiro amarelo, feijão preto cv. BT-2 e C. juncea, inoculada com o isolado M1 mostrou sintomas de infecção. Testes serológicos de PTA-ELISA e 'Western blot', com amostras dessas plantas, deram reações negativas.

Tabela 3. Eficiência de transmissão mecânica do potyvírus causador de mosqueado em maracujazeiro, isolado M1, para abobrinha-de-moita cv. Caserta, maracujazeiro amarelo, feijão preto cv. BT-2 e Crotalaria 
juncea utilizando plantas infectadas de 'Caserta', maracujazeiro amarelo, feijão preto cv. BT-2 e C. juncea como fontes de inóculo

\begin{tabular}{ccccc}
\hline \multirow{2}{*}{$\begin{array}{c}\text { Fonte de inóculo } \\
\end{array}$} & № de plantas inoculadas/ $\mathrm{n}^{\circ}$ de plantas infectadas* \\
& 'Caserta' & Maracujazeiro & BT-2 & C. juncea \\
\hline 'Caserta' & $10 / 10(100)$ & $50 / 0(0)$ & $8 / 0(0)$ & $8 / 0(0)$ \\
Maracujazeiro & $8 / 8(100)$ & $8 / 8(100)$ & $8 / 8(100)$ & $8 / 8(100)$ \\
BT-2 & $8 / 8(100)$ & $8 / 8(100)$ & $8 / 8(100)$ & $8 / 8(100)$ \\
C. juncea & $8 / 8(100)$ & $8 / 8(100)$ & $8 / 8(100)$ & $8 / 8(100)$ \\
\hline
\end{tabular}

*Infecção comprovada por teste serológico de PTA-ELISA e/ou 'Western blot' 


\subsubsection{Efeito da espécie fonte de inóculo na eficiência da transmissão por afídeos}

Os dados referentes aos testes de transmissão do vírus causador de mosqueado em maracujazeiro, isolado $\mathrm{M} 1$, para abobrinha-de-moita cv. Caserta, maracujazeiro amarelo, feijão preto cv. BT-2 e C. juncea empregando afídeos encontram-se na tabela 4.

Quando foram empregadas, como fonte de inóculo, plantas de maracujazeiro amarelo, feijão preto cv. BT-2 e $C$. juncea, tanto $M$. persicae como $A$. gossypii adquiriram e transmitiram com grande eficiência o isolado M1 para as 4 espécies de plantas-teste. Em média, para $M$. persicae, foram observadas eficiências de transmissão de 93,7\%, 90,6\% e 87,5\%, quando este adquiriu o potyvírus em maracujazeiro amarelo, feijão preto cv. BT-2 e $C$. juncea, respectivamente. No caso de A. gossypii foram observadas eficiências médias de transmissão de $100 \%, 93,7 \%$ e $87,5 \%$, para as aquisições efetuadas nas mesmas fontes acima citadas.

Novamente, como observado na transmissão mecânica (Tabela 3), a abobrinha-de-moita cv. Caserta não se revelou boa fonte de inóculo para aquisição e posterior transmissão do isolado $\mathrm{M} 1$ por meio de afídeos, exceto para plantas da mesma espécie. Mesmo assim, a eficiência de transmissão foi mais baixa do que nos casos anteriores, sendo de $25 \%$ e $50 \%$ para $M$. persicae e A. gossypii, respectivamente.

$\mathrm{Na}$ tabela 5 está o resultado da eficiência de transmissão do potyvírus causador de mosqueado em maracujazeiro, isolado M1, para abobrinha-demoita cv. Caserta e maracujazeiro amarelo, por M. persicae e A. gossypii, utilizando como fonte de inóculo folhas de abobrinha 'Caserta' em 3 estádios de desenvolvimento (início de desenvolvimento - ID, parcialmente expandida - PE e folha madura - FM). Os resultados corroboram a baixa eficiência da 'Caserta' como fonte para aquisição e posterior transmissão do isolado do potyvírus 
Tabela 4. Eficiência de Myzus persicae (MP) e Aphis gossypii (AG) na transmissão do potyvírus causador de mosqueado em maracujazeiro, isolado M1, para abobrinha-de-moita cv. Caserta, maracujazeiro amarelo, feijão preto cv. BT-2 e Crotalaria juncea, utilizando folhas do ponteiro de 'Caserta', maracujazeiro amarelo, feijão preto cv. BT-2 e C. juncea infectadas como fontes de inóculo

\begin{tabular}{ccccccccc}
\hline $\begin{array}{c}\text { Fonte de } \\
\text { inóculo }\end{array}$ & \multicolumn{8}{c}{ № de plantas inoculadas/ $\mathrm{n}^{\circ}$ de plantas infectadas* } \\
& 'Caserta' & Maracujazeiro & BT-2 & \multicolumn{2}{c}{ C. juncea } \\
& MP & AG & MP & AG & MP & AG & MP & AG \\
\hline 'Caserta' & $8 / 2$ & $8 / 4$ & $8 / 0$ & $8 / 0$ & $8 / 0$ & $8 / 0$ & $8 / 0$ & $8 / 0$ \\
& $(25,0)$ & $(50,0)$ & $(0)$ & $(0)$ & $(0)$ & $(0)$ & $(0)$ & $(0)$ \\
Maracujazeiro & $8 / 8$ & $8 / 8$ & $8 / 8$ & $8 / 8$ & $8 / 8$ & $8 / 8$ & $8 / 6$ & $8 / 8$ \\
& $(100,0)$ & $(100,0)$ & $(100,0)$ & $(100,0)$ & $(100,0)$ & $(100,0)$ & $(75,0)$ & $(100,0)$ \\
BT-2 & $8 / 7$ & $8 / 8$ & $8 / 6$ & $8 / 7$ & $8 / 8$ & $8 / 7$ & $8 / 8$ & $8 / 8$ \\
& $(87,5)$ & $(100,0)$ & $(75,0)$ & $(87,5)$ & $(100,0)$ & $(87,5)$ & $(100,0)$ & $(100,0)$ \\
C. juncea & $8 / 8$ & $8 / 7$ & $8 / 7$ & $8 / 7$ & $8 / 6$ & $8 / 6$ & $8 / 7$ & $8 / 8$ \\
& $(100,0)$ & $(87,5)$ & $(87,5)$ & $(87,5)$ & $(75,0)$ & $(75,0)$ & $(87,5)$ & $(100,0)$ \\
\hline
\end{tabular}

* Infecção comprovada por teste serológico de PTA-ELISA e/ou 'Western blot' 
Tabela 5. Eficiência de Myzus persicae e Aphis gossypii na transmissão do potyvírus causador de mosqueado em maracujazeiro, isolado M1, para abobrinha-de-moita cv. Caserta e maracujazeiro amarelo, adquirido em folhas de 'Caserta' em 3 estádios de desenvolvimento (início de desenvolvimento- ID, parcialmente expandida- PE e folha madura- FM)

\begin{tabular}{|c|c|c|c|c|c|c|}
\hline \multirow{3}{*}{ Afídeos } & \multicolumn{6}{|c|}{$\begin{array}{l}\text { № de plantas inoculadas } / \mathrm{n}^{\circ} \text { de plantas infectadas* } \\
\text { (\% de transmissão) }\end{array}$} \\
\hline & \multicolumn{3}{|c|}{ 'Caserta' } & \multicolumn{3}{|c|}{ Maracujazeiro } \\
\hline & ID & PE & FM & $\mathbb{D}$ & PE & FM \\
\hline Myzus persicae & $15 / 3(20)$ & $15 / 0(0)$ & $15 / 0(0)$ & $15 / 0(0)$ & $15 / 0(0)$ & $15 / 0(0)$ \\
\hline Aphis gossypii & $15 / 5(34)$ & $15 / 0(0)$ & $15 / 0(0)$ & $15 / 0(0)$ & $15 / 0(0)$ & $15 / 0(0)$ \\
\hline
\end{tabular}

* Infecção comprovada por teste serológico de PTA-ELISA e/ou 'Western blot' 
causador de mosqueado. Só foi observada a transmissão, ainda que com baixa eficiência, apenas quando se empregou folhas novas para a aquisição do vírus pelos afídeos. Neste caso, M. persicae e A. gossypii transmitiram o isolado M1 com eficiências de $20 \%$ e $34 \%$, respectivamente. As folhas parcialmente expandidas e as maduras não foram boas doadoras de inóculo para a transmissão por essas duas espécies de afídeos. A transmissão também só foi efetiva de abobrinha-de-moita para abobrinha-de-moita.

\subsection{Peso molecular da proteína da capa protéica e do RNA viral}

Reação serológica, em testes de "Western blot", revelou a presença de uma proteína com o peso de aproximadamente $32 \mathrm{kDa}$, tanto no purificado viral como em extratos de plantas de maracujazeiro e abobrinha-de-moita cv. Caserta infectadas com o potyvírus causador de mosqueado em maracujazeiro (Figura 7).

No isolamento do RNA viral, obteve-se uma concentração de 99,2 $\mu \mathrm{g}$ de RNA/ $\mu \mathrm{L}$ a partir de uma alíquota de $150 \mu \mathrm{L}$ do vírus purificado. O resultado da eletroforese em gel de agarose 1\%, utilizando como padrão um marcador de peso molecular de $1 \mathrm{~Kb}$, revelou peso molecular próximo a 10.000 pb para este RNA (Figura 8).

\subsection{Relacionamento serológico com outros potyvirus}

Os valores de absorbância $\left(\mathrm{A}_{450}\right)$, obtidos em teste de PTA-ELISA utilizando-se antissoros contra a proteína da capa protéica do potyvírus causador de mosqueado em maracujazeiro, do PWV, do ZYMV e do PRSV-W, e os respectivos antígenos homólogos encontram-se na tabela 6.

O antissoro contra a proteína da capa protéica do PWV e do potyvírus causador do mosqueado reagiram com os antígenos homólogos e heterólogos 


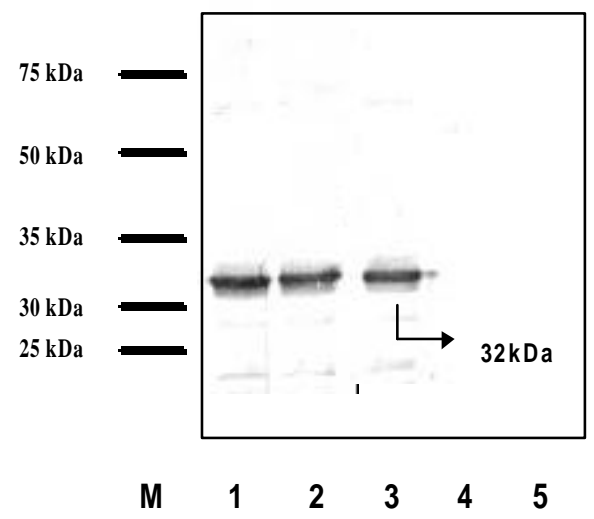

Figura 7 - Teste de 'Western blot' utilizando antissoro produzido contra 0 potyvírus causador de mosqueado. (M) marcador de peso molecular; (1) purificado do potyvírus do mosqueado; (2) extrato de maracujazeiro ifectado com o potyvírus do mosqueado; (3) extrato de 'Caserta' infectada com o potyvírus do mosqueado; (4) 'Caserta' sadia e (5) maracujazeiro sadio

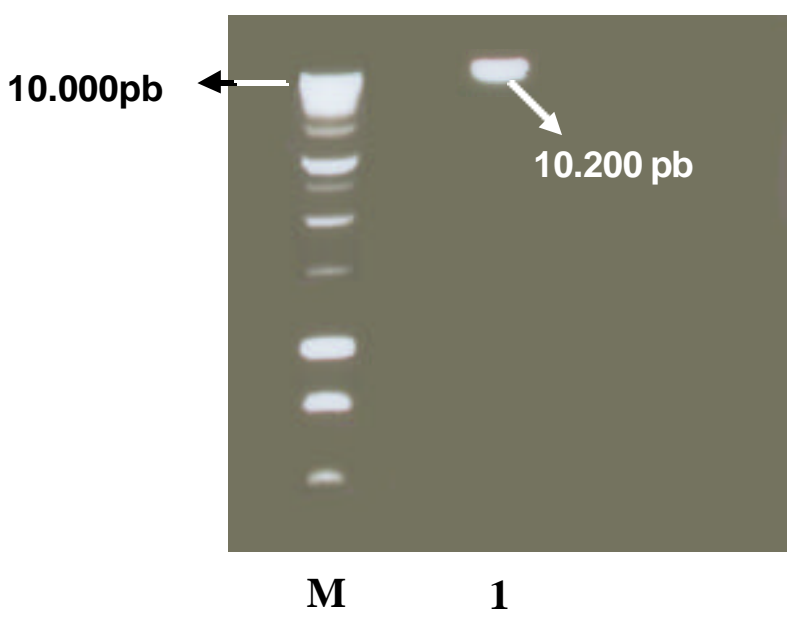

Figura 8 - RNA isolado de um purificado do potyvírus causador de mosqueado em maracujazeiro. (M) marcador de peso molecular; (1) RNA do potyvírus do mosqueado 
Tabela 6. Valores de absorbância $\left(A_{450}\right)$, obtidos em teste de PTA-ELISA utilizando antissoros diluídos 1:1000, contra a proteína da capa protéica do potyvírus do mosqueado, do PWV, do ZYMV e do PRSV-W

\begin{tabular}{ccccc}
\hline Amostras & \multicolumn{4}{c}{ Antissoros } \\
& Mosqueado* & PWV* & ZYMV & PRSV-W \\
\hline Mosqueado** $^{*}$ & 1,002 & 0,730 & 0,071 & 0,093 \\
PWV $^{* *}$ & 0,862 & 0,843 & 0,076 & 0,089 \\
ZYMV $^{* \star *}$ & 0,103 & 0,180 & 0,412 & 0,109 \\
PRSV-W*** & 0,128 & 0,127 & 0,065 & 0,892 \\
Maracujazeiro sadio & 0,098 & 0,100 & 0,052 & 0,059 \\
Abobrinha sadia & 0,075 & 0,106 & 0,065 & 0,093
\end{tabular}

* Antissoro pré-adsorvido com extrato de plantas sadias de abobrinha-de-moita cv. Caserta e maracujazeiro amarelo.

${ }^{* *}$ Amostras foliares de maracujazeiro amarelo

${ }^{* \star \star}$ Amostras foliares de abobrinha-de-moita cv. Caserta 
nos testes de PTA-ELISA. Extratos de plantas portadoras destes vírus apresentaram absorbâncias, no comprimento de onda de $450 \mathrm{~nm}$, superiores a 7 vezes o valor da leitura da amostra sadia, independente do antissoro empregado. Os antissoros contra o PRSV-W e o ZYMV não reagiram com o potyvírus do mosqueado e o PWV.

Teste serológico de 'Western blot' empregando extratos foliares de maracujazeiros infectados com PWV e com o potyvírus causador de mosqueado, separadamente, e seus respectivos antissoros corroboraram os resultados obtidos no teste de PTA-ELISA para determinação de relacionamento serológico (Figura 9). Além disso mostra que a proteína da capa protéica de ambos tem o mesmo peso molecular.

\subsection{Proteção entre isolados do potyvírus causador de mosqueado em maracujazeiro e do PWV}

Os dados referentes aos experimentos de proteção entre os isolados PWV-1 e PWV-2 e os isolados M1, M2 e M3 do potyvírus causador de mosqueado em maracujazeiro, em plantas de $P$. edulis f. flavicarpa e de $C$. juncea, avaliada através da recuperação dos isolados desafiantes em plantas de abobrinha-de-moita cv. Caserta, encontram-se na tabela 7.

Foi observado nos dois experimentos que todas as plantas de maracujazeiro previamente infectadas com o isolado PWV-1 ou PWV-2 foram superinfectadas pelos isolados M1, M2 e M3. Sete dias após a superinoculação foi possível recuperar, para plantas de abobrinha-de-moita cv. Caserta, os isolados M1 e M2 dos ponteiros de duas plantas de maracujazeiro previamente infectadas com o isolado PWV-1. Aos 21 dias da superinoculação já haviam sido recuperados, em plantas de abobrinha-de-moita, os isolados desafiantes de todas as plantas de maracujazeiro inicialmente infectadas com os isolados PWV-1 e PWV-2. A comprovação da recuperação foi feita pela observação visual de sintomas de amarelecimento de nervuras nas plantas de 'Caserta', 


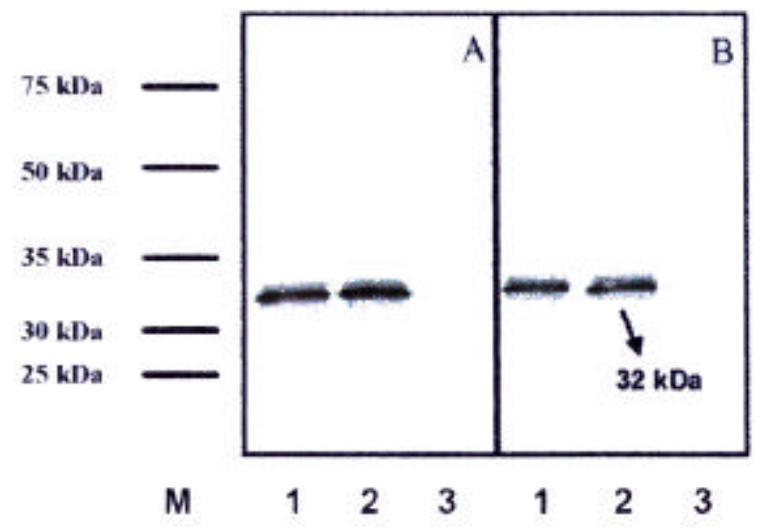

Figura 9 - Teste de 'Western blot' utilizando antissoro contra o potyvírus causador de mosqueado (A) e contra o PWV (B). (M) marcador de peso molecular; (1) extrato de maracujazeiro infectado com o potyvírus do mosqueado; (2) extrato de maracujazeiro infectado com o PWV; (3) extrato de maracujazeiro sadio 
Tabela 7. Experimentos de proteção entre os isolados PWV-1 e PWV-2 e os isolados M1, M2 e M3 do potyvírus causador de mosqueado em maracujazeiro, em plantas de Passiflora edulis f. flavicarpa e Crotalaria juncea, avaliado através da recuperação dos isolados desafiantes em plantas de abobrinha-de-moita cv. Caserta

\begin{tabular}{|c|c|c|c|c|c|c|c|}
\hline \multirow{3}{*}{ Planta teste } & \multicolumn{6}{|c|}{ Experimento 1} & \\
\hline & \multirow[t]{2}{*}{$\begin{array}{l}\text { № de plantas } \\
\text { inoculadas } \\
\text { com o PWV-1* }\end{array}$} & \multirow[t]{2}{*}{$\begin{array}{c}\text { Isolados } \\
\text { desafiantes }\end{array}$} & \multirow{2}{*}{$\begin{array}{c}\text { № de } \\
\text { plantas } \\
\text { desafiadas } \\
\text { por isolado }\end{array}$} & \multicolumn{4}{|c|}{$\begin{array}{l}\text { № de plantas onde ocorreu a recuperação do } \\
\text { isolado desafiante em função do no o de dias após a } \\
\text { superinoculação }\end{array}$} \\
\hline & & & & 7 dias & 14 dias & 21 dias & 35 dias \\
\hline \multirow{3}{*}{$\begin{array}{l}\text { Passiflora } \\
\text { edulis } \mathrm{f} . \\
\text { Flavicarpa }\end{array}$} & \multirow{3}{*}{24} & M1 & 8 & 1 & 3 & 8 & $\mathrm{NT}^{\star *}$ \\
\hline & & M2 & 8 & 1 & 2 & 8 & NT \\
\hline & & M3 & 8 & 0 & 1 & 8 & NT \\
\hline \multirow{3}{*}{$\begin{array}{c}\text { Crotalaria } \\
\text { juncea }\end{array}$} & \multirow{3}{*}{24} & M1 & 8 & 0 & 0 & 0 & 0 \\
\hline & & M2 & 8 & 0 & 0 & 0 & 0 \\
\hline & & M3 & 8 & 0 & 0 & 0 & 0 \\
\hline \multirow{3}{*}{ Planta teste } & \multicolumn{7}{|c|}{ Experimento 2} \\
\hline & \multirow[t]{2}{*}{$\begin{array}{l}\text { № de plantas } \\
\text { inoculadas } \\
\text { com o PWV-2* }\end{array}$} & \multirow[t]{2}{*}{$\begin{array}{c}\text { Isolados } \\
\text { desafiantes }\end{array}$} & $\begin{array}{c}\text { № de } \\
\text { plantas } \\
\text { desafiadas }\end{array}$ & \multicolumn{4}{|c|}{$\begin{array}{l}\text { № de plantas onde ocorreu a recuperação do } \\
\text { isolado desafiante em função do oㅡo de dias após a } \\
\text { superinoculação }\end{array}$} \\
\hline & & & por isolado & 7 dias & 14 dias & 21 dias & 35 dias \\
\hline \multirow{4}{*}{$\begin{array}{l}\text { Passiflora } \\
\text { edulis } \mathrm{f} . \\
\text { Flavicarpa }\end{array}$} & \multirow{3}{*}{18} & M1 & 6 & 0 & $T$ & 6 & NT \\
\hline & & M2 & 6 & 0 & 2 & 6 & NT \\
\hline & & M3 & 6 & 0 & 3 & 6 & NT \\
\hline & \multirow{3}{*}{18} & M1 & 6 & 0 & 0 & 0 & 0 \\
\hline \multirow{2}{*}{$\begin{array}{c}\text { Crotalaria } \\
\text { juncea }\end{array}$} & & M2 & 6 & 0 & 0 & 0 & 0 \\
\hline & & M3 & 6 & 0 & 0 & 0 & 0 \\
\hline
\end{tabular}

* comprovação de infecção efetuada por teste serológico de PTA-ELISA

${ }^{* *}$ NT- não testado 
que foram inoculadas com os extratos vegetais oriundos de folhas dos ponteiros das plantas desafiadas.

O teste de proteção em $C$. juncea, por outro lado, mostrou que os isolados PWV-1 e PWV-2 protegeram as plantas contra a infecção com os isolados M1, M2 e M3 do potyvírus do mosqueado. Nenhum desses isolados foi recuperado para plantas de 'Caserta' inoculadas com extratos do ponteiro das plantas infectadas, até o 35 dia após o desafio.

Tanto as plantas de maracujazeiro como as de crotalária sadias, que foram inoculadas com os isolados do potyvírus do mosqueado, para checar a infectividade dos mesmo por ocasião do desafio, exibiram sintomas após 10 dias da inoculação.

\subsection{Efeito do potyvírus causador de mosqueado no desenvolvimento das plantas de maracujazeiro em casa-de-vegetação}

Os dados referentes às avaliações de altura e área foliar das plantas infectadas com os isolados M1, M2 e M3 do potyvírus do mosqueado e com o PWV-1 e PWV-2, para fins de comparação, em 2 experimentos independentes, encontram-se nas figuras 10 e 11, respectivamente. Na maioria dos casos, as plantas de maracujazeiro infectadas com os 3 isolados do potyvírus causador de mosqueado não mostraram reduções significativas na altura e na área foliar, quando comparadas com os controles sadios. $\mathrm{O}$ isolado $\mathrm{M} 3$ se mostrou, em média, o mais agressivo, causando reduções de aproximadamente $26 \%$ e $40 \%$ em altura e área foliar, respectivamente. Quando comparadas alturas e áreas foliares das plantas infectadas com os isolados M1, M2 e M3, com as daquelas infectadas com os isolados PWV-1 e PWV-2, observou-se na maioria dos casos maiores danos ocasionados pelos isolados do PWV. As reduções em altura e área foliar acarretadas pelos isolados do PWV, quando comparadas à testemunha sadia, chegaram a valores da ordem de $52 \%$ e $83 \%$, respectivamente. 


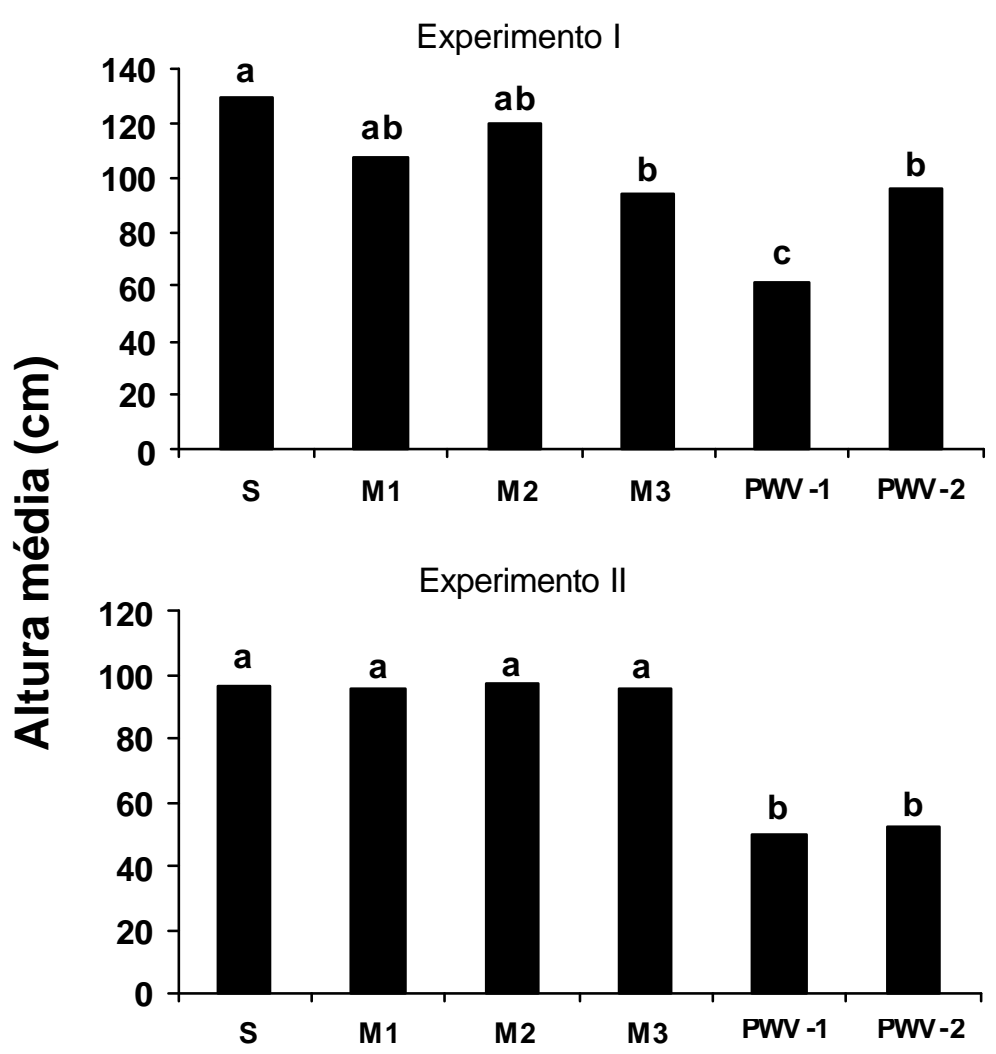

Tratamentos

Figura 10 - Altura média de plantas sadias (S), infectadas com três isolados do potyvírus causador de mosqueado em maracujazeiro (M1, M2 e M3) e com dois isolados do PWV (PWV-1 e PWV-2), em casa-devegetação. Barras com letras distintas, dentro de cada experimento, diferem entre si ao nível de $5 \%$ pelo teste de Tukey 


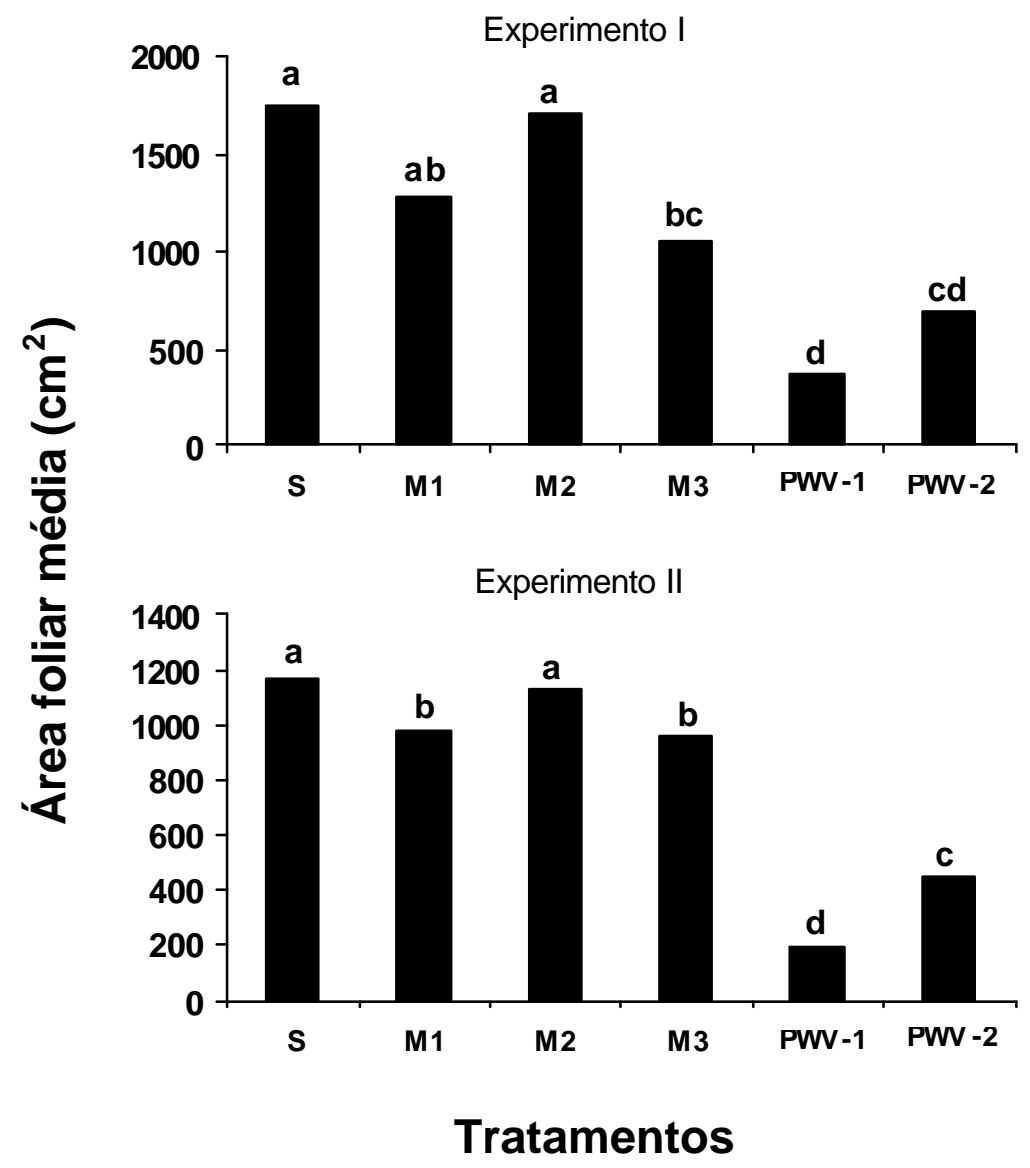

Figura 11 - Área foliar média de plantas sadias (S), infectadas com três isolados do potyvírus causador de mosqueado em maracujazeiro (M1, M2 e M3) e com dois isolados do PWV (PWV-1 e PWV-2), em casa-devegetação. Barras com letras distintas, dentro de cada experimento, diferem entre si ao nível de $5 \%$ pelo teste de Tukey 
Os resultados das avaliações de pesos fresco e seco do sistema radicular e da parte aérea (Tabelas 8 e 9) foram semelhantes aos obtidos nas medidas de altura e área foliar. Quando comparadas æ̀ testemunhas sadias as plantas inoculadas com o isolado $M 3$ apresentaram reduções da ordem de $27 \%$ a $45 \%$, em peso fresco e seco do sistema radicular e da parte aérea, enquanto, nas plantas inoculadas com os isolados do PWV foram observadas reduções de $50 \%$ a $80 \%$.

\subsection{Seqüências de nucleotídeos e de aminoácidos deduzidos do gene da capa protéica do potyvírus causador de mosqueado em maracujazeiro}

A partir do RNA total extraído de plantas de maracujazeiro infectadas com os isolados M2 e M3, separadamente, amplificourse, com o auxílio dos primers PV1 e PV2, um fragmento de aproximadamente 1.700 pares de bases através da reação de RT-PCR (Figura 12). Após a clonagem, estes fragmentos foram seqüenciados. Quando se promoveu, separadamente, o alinhamento destas seqüências com a do Cowpea aphid-borne mosaic virus (AF348210), foi identificado todo o gene da capa protéica com 825 nucleotídeos, toda a região não traduzida do terminal 3' com 230 nucleotídeos, sendo o restante dos nucleotídeos parte do gene responsável pela inclusão nuclear $b$.

As tabela 10 e 11 apresentam, respectivamente, a porcentagem de identidade entre as seqüências de nucleotídeos e de aminoácidos deduzidos do gene da capa protéica e a porcentagem de identidade entre as seqüências da região 3' não traduzida dos isolados M2 e M3 do potyvírus causador de mosqueado em maracujazeiro e de outros potyvírus. A figura 13 apresenta um dendrograma construído com base na seqüência de nucleotídeos da capa protéica dos isolados do potyvírus causador do mosqueado em maracujazeiro e os demais potyvírus. As figuras 14, 15 e 16 representam os alinhamentos das seqüências consenso de nucleotídeos do gene da capa protéica, da região 3' 
Tabela 8. Peso fresco da parte aérea, do sistema radicular e total, de plantas de maracujazeiro sadias, infectadas com três isolados do potyvírus causador de mosqueado em maracujazeiro (M1, M2 e M3) e com dois isolados do PWV (PWV-1 e PWV-2), em dois experimentos distintos, realizados em casa-de-vegetação

\begin{tabular}{ccccccc}
\hline Partes da planta & \multicolumn{7}{c}{ Peso fresco (g) } \\
& Sadia & M1 & M2 & M3 & PWV-1 & PWV- 2 \\
\hline Experimento I & & & & & & \\
Parte aérea & $59,0 \mathrm{a}^{*}$ & 49,4 ab & $59,3 \mathrm{a}$ & $41,7 \mathrm{bc}$ & $24,0 \mathrm{~d}$ & $31,4 \mathrm{~cd}$ \\
Raiz & $20,7 \mathrm{a}$ & $16,7 \mathrm{ab}$ & $20,6 \mathrm{a}$ & $12,7 \mathrm{bc}$ & $5,2 \mathrm{~d}$ & $9,3 \mathrm{~cd}$ \\
Total & $79,7 \mathrm{a}$ & 66,1 ab & $79,3 \mathrm{a}$ & $54,4 \mathrm{bc}$ & $29,2 \mathrm{~d}$ & $40,7 \mathrm{~cd}$ \\
Experimento II & & & & & & \\
& & & & & & \\
Parte aérea & $44,9 \mathrm{a}$ & $36,2 \mathrm{ab}$ & $41,6 \mathrm{a}$ & $34,2 \mathrm{~b}$ & $9,2 \mathrm{~d}$ & $18,8 \mathrm{c}$ \\
Raiz & $12,8 \mathrm{a}$ & $9,3 \mathrm{ab}$ & $10,5 \mathrm{a}$ & $7,9 \mathrm{~b}$ & $2,0 \mathrm{c}$ & $4,7 \mathrm{c}$ \\
Total & $57,7 \mathrm{a}$ & $45,5 \mathrm{ab}$ & $52,1 \mathrm{a}$ & $42,1 \mathrm{~b}$ & $11,2 \mathrm{c}$ & $23,5 \mathrm{c}$ \\
\hline
\end{tabular}

* Linhas com letras distintas, dentro de cada experimento (I e II), diferem entre si ao nível de significância de $5 \%$ pelo teste de Tukey. 
Tabela 9. Peso seco da parte aérea, do sistema radicular e total, de plantas de maracujazeiro sadias, infectadas com três isolados do potyvírus causador de mosqueado em maracujazeiro (M1, M2 e M3) e com dois isolados do PWV (PWV-1 e PWV-2), em dois experimentos distintos, realizados em casa-de-vegetação

\begin{tabular}{ccccccc}
\hline Partes da planta & \multicolumn{7}{c}{ Peso seco (g) } \\
& Sadia & M1 & M2 & M3 & PWV-1 & PWV- 2 \\
\hline Experimento I & & & & & & \\
Parte aérea & $19,4 \mathrm{a}^{*}$ & $17,3 \mathrm{ab}$ & $19,4 \mathrm{a}$ & $10,8 \mathrm{bc}$ & $5,6 \mathrm{c}$ & $7,7 \mathrm{c}$ \\
Raiz & $3,7 \mathrm{a}$ & $3,1 \mathrm{a}$ & $3,5 \mathrm{a}$ & $2,7 \mathrm{ab}$ & $1,1 \mathrm{c}$ & $1,9 \mathrm{bc}$ \\
Total & $23,1 \mathrm{a}$ & $20,4 \mathrm{a}$ & $22,9 \mathrm{a}$ & $12,5 \mathrm{~b}$ & $6,7 \mathrm{c}$ & $8,6 \mathrm{c}$ \\
Experimento II & & & & & & \\
Parte aérea & $14,7 \mathrm{a}$ & $12,0 \mathrm{ab}$ & $13,8 \mathrm{a}$ & $10,2 \mathrm{~b}$ & $4,2 \mathrm{c}$ & $6,4 \mathrm{c}$ \\
Raiz & $2,9 \mathrm{a}$ & $2,4 \mathrm{ab}$ & $2,6 \mathrm{a}$ & $1,7 \mathrm{~b}$ & $0,6 \mathrm{c}$ & $1,1 \mathrm{bc}$ \\
Total & $17,6 \mathrm{a}$ & $14,4 \mathrm{ab}$ & $16,4 \mathrm{a}$ & $11,9 \mathrm{~b}$ & $4,8 \mathrm{c}$ & $7,5 \mathrm{c}$ \\
\hline
\end{tabular}

* Linhas com letras distintas, dentro de cada experimento (I e II), diferem entre si ao nível de significância de $5 \%$ pelo teste de Tukey 


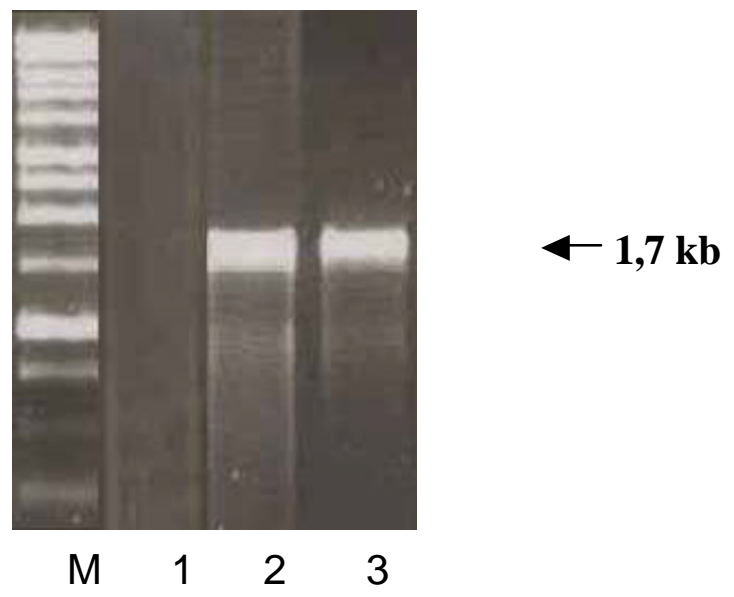

Figura 12 - Fragmentos amplificados por RT-PCR, observados em gel de agarose $1 \%$, corado com brometo de etídeo. $\mathrm{M}$, marcador de peso molecular (1kb DNA Ladder); 1, amostra sadia; 2 e 3, fragmentos de aproximadamente 1.700 pares de bases dos isolados M2 e M3 do vírus causador de mosqueado em maracujazeiro, respectivamente 
Tabela 10. Porcentagem de identidade entre as seqüências de nucleotídeos (diagonal inferior) e as seqüências de aminoácidos deduzidos (diagonal superior) do gene da capa protéica dos isolados M2 e M3 do potyvírus causador de mosqueado em maracujazeiro e de mais 10 outros potyvírus

\begin{tabular}{ccccccccccccc}
\hline & M2 & M3 & PWV & PWV SP & PWV T & PWV J & PWV A & CABMV & SMV & ZYMV & WMV-2 & PRSV-W \\
\hline M2 & ----- & 98 & 99 & 98 & 66 & 66 & 68 & 90 & 68 & 65 & 69 & 54 \\
M3 & 98 & ----- & 98 & 97 & 66 & 66 & 68 & 90 & 68 & 65 & 69 & 54 \\
PWV & 99 & 98 & ----- & 98 & 66 & 67 & 68 & 90 & 68 & 65 & 69 & 55 \\
F-101 & & & & & & & & & & & & \\
PWV SP & 97 & 97 & 97 & ----- & 67 & 67 & 68 & 90 & 68 & 66 & 70 & 55 \\
PWV T & 70 & 70 & 70 & 70 & ----- & 95 & 67 & 64 & 71 & 67 & 71 & 52 \\
PWV J & 70 & 70 & 70 & 70 & 98 & ----- & 67 & 64 & 72 & 67 & 72 & 52 \\
PWV A & 75 & 75 & 75 & 75 & 74 & 72 & ----- & 66 & 68 & 66 & 69 & 49 \\
CABMV & 87 & 87 & 87 & 86 & 70 & 62 & 73 & ----- & 76 & 67 & 67 & 49 \\
SMV & 70 & 69 & 70 & 70 & 66 & 66 & 74 & 71 & ----- & 69 & 82 & 51 \\
ZYMV & 59 & 58 & 59 & 58 & 61 & 60 & 71 & 58 & 62 & ----- & 69 & 50 \\
WMV-2 & 72 & 72 & 72 & 73 & 74 & 74 & 75 & 71 & 85 & 63 & ----- & 54 \\
PRSV-W & 61 & 60 & 61 & 60 & 51 & 51 & 64 & 61 & 57 & 58 & 62 & ----- \\
\hline
\end{tabular}


Tabela 11. Porcentagem de identidade entre as seqüências do terminal 3' não traduzido dos isolados M2 e M3 do potyvírus causador de mosqueado em maracujazeiro e de mais 8 outros potyvírus.

\begin{tabular}{|c|c|c|c|c|c|c|c|c|c|c|}
\hline & M2 & M3 & $\begin{array}{l}\text { PWV } \\
\text { F-101 }\end{array}$ & PWV SP & PWV T & PWV J & PWV A & CABMV & ZYMV & PRSV-W \\
\hline M2 & ---- & ----- & ---- & ----- & ----- & ----- & ----- & ---- & ----- & ----- \\
\hline M3 & 99 & ----- & ----- & ----- & ----- & ----- & ----- & ----- & ----- & ----- \\
\hline $\begin{array}{l}\text { PWV } \\
\text { F-101 }\end{array}$ & 100 & 99 & ----- & ----- & ----- & ----- & ----- & ----- & ----- & ----- \\
\hline PWV SP & 95 & 96 & 95 & ----- & ----- & ----- & ----- & ----- & ----- & ----- \\
\hline PWV T & 36 & 36 & 36 & 33 & ----- & ----- & ----- & ----- & ----- & ----- \\
\hline PWV J & 36 & 36 & 36 & 33 & 73 & ----- & ----- & ----- & ----- & ----- \\
\hline PWV A & 32 & 32 & 32 & 31 & 67 & 73 & ----- & ----- & ----- & ----- \\
\hline CABMV & 91 & 91 & 91 & 94 & 36 & 36 & 30 & ----- & ----- & ----- \\
\hline ZYMV & 29 & 29 & 29 & 36 & 11 & 11 & 31 & 37 & ---- & ----- \\
\hline PRSV-W & 8 & 8 & 8 & 19 & 14 & 14 & 10 & 11 & 12 & ----- \\
\hline
\end{tabular}




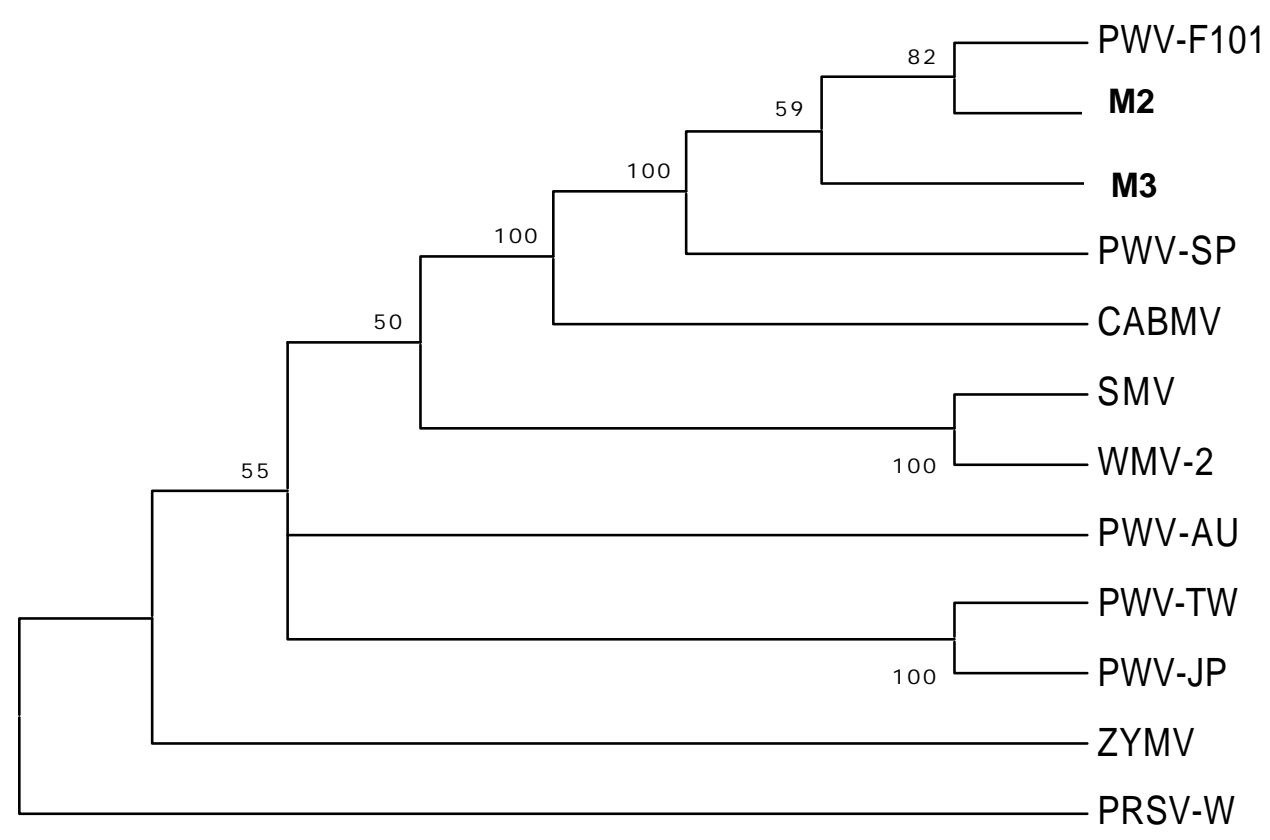

Figura 13 - Dendrograma construído com base na seqüência completa de nucleotídeos do gene da capa protéica dos isolados do potyvirus causador do mosqueado em maracujazeiro e outros potyvirus. A árvore foi gerada com o programa MEGA. As porcentagens de "bootstrap" com 2000 repetições são indicadas nos braços da árvore 
$\underset{F-191}{M 2}$

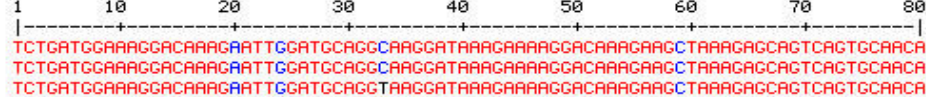

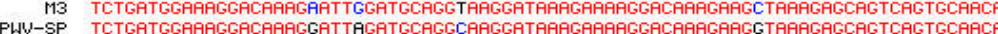

$\begin{array}{llllllll}81 & 90 & 100 & 110 & 120 & 130 & 140 & 150\end{array}$

M2 ARAGCARGCARAGARTARAGGAACTAAGGAAACAGAGAGGGACGTTTCAACTAGTTCTTCAGGGCAACTAGTTCCACGCT

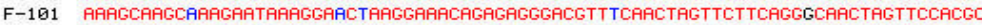

PWV-SP ARAGCAAGCGARGARTARAGGAACCAAGGAAACAGAGAGGGACGTTGCAACTAGTTCTTCAGGACAACTAGTTCCACGCT

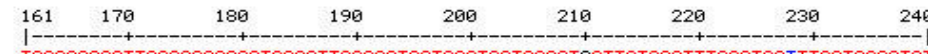

M2 TACAAAAGATTAGCAFAFAGATGAACTTGCCCATGGTCGCTGGTAGAGTGCTTCTCAATTTGGATCATTTGATAGAATAT

F-101 TACAAAAGATTAGCAFAAAGATGAACTTGCCCATGGTCGCTGGTAGAGTGCTTCTCAATTTGGATCATTTGATAGAATAT

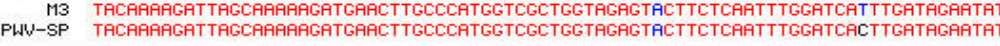

$\begin{array}{llllllll}241 & 250 & 260 & 270 & 280 & 290 & 300 & 310\end{array}$

$M 2$ AAGCCAGCGCARATTGATCTATACAACACCAGAGCATCARAGACACAGCTCAGCAAATGGTTTGAAGCCATTAAGGAAG

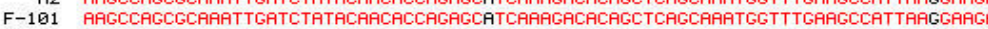

M3 AAGCCAGCGCAARTTGATCTATACAACACCAGAGCTTCAAAGACACAGCTCAGCARATGGTTTGAAGCCATTAPACARC PWV-SP ARGCCAGCGCARATTGATCTATACAACACCAGAGCTTCARAGACACAGCTCAGCARATGGTTTGAAGCCATTARAGAAGA

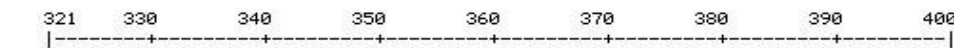

$M 2$ GTACGAGCTGGATGAAGACAAGATGGGTGTTATCATGAATAGGTTCATGGTTTGGTGCATTGARAATGGAACTTCACCTG

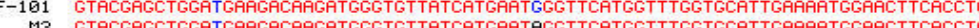
PWU-SP GTACGAGCTGGACGARGACAAGATGGGTGTTATCATGARTGGGTTCATGGTTTGGTGCATTGARARTGGAACTTCACCT

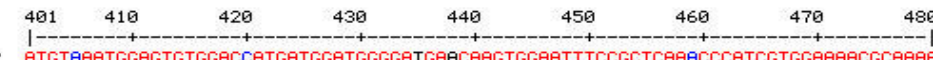

191 - 1 1 ATG PWU-SP ATGTGAATGGAGTGTGGACARTGATGGATGGGGACGAGCAAGTGGAATTTCCGCTCAAGCCCATCGTGGAAAACGCAAAP

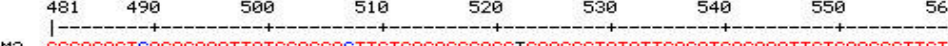
F-101 CCCACACTCAGACARATTATGCACCACTTCTCAGACGCAGCTGAAGCGTATATTGAGATGAGARATTCTGAAGGGTTCT

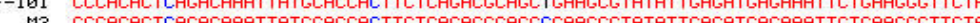
PWV-SP

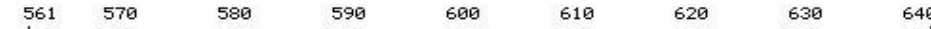
M2 CATGCCCAGGTATGGACTGCTGAGGAATTTAAGAGACAAGAGCTTAGCAAGGTATGCTTTCGATTTCTATGAAGTCACG -101 CATGCCCAGGTATGGACTGCTGAGGAATTTRAGAGACAAGAGCTTAGCAAGGTATGCTTTCGATTTCTATGAAGTCACG PWW-SP CATGCCCAGGTACGGACTGCTGAGGAATTTAAGGGGCARGAGCTTAGCARGGTATGCTTTCGATTTCTATGAAGFTCACGT

$\begin{array}{llllllll}641 & 650 & 660 & 670 & 680 & 690 & 700 & 719\end{array}$

M2 CTAAGACTTCTGATAGAGCAAGGGAAGCAATAGCACAAATGAAGGCTGCAGCTCTCGCCAACGTTAACACCAGGATGTT F-101 CTARGACTTCTGATAGAGCAAGGLARGCHATAGCACARATGGAGLCTLCAGCTCTCGCCAACGTTARCACCAGGATGTTT MS CTARGACTTCTGATAGAGCARGGGARGCRATAGCACARATGARGGCTGCAGCTCTCGCCARCGTTRACACCAGGATGTTT PWU-SP CTAAGACTTCTGATAGAGCAAGGGAAGCAATAGCGCAAATGAAGGCTGCAGCTCTCGCCAACGTTAACACCAGGATGTTT

$\begin{array}{lllllllll}721 & 730 & 740 & 750 & 760 & 770 & 780 & 790 & 800\end{array}$

M2 GGCCTGGATGGGARTGTGGCAACAACTAGTGAGAACACTGAGAGGCACACTGCCACTGATGTTAGTCAGARTATGCATTC F-101 GGCCTGGATGGGAATGTGGCAACAACTAGTGAGAACACTGAGAGGCACACTGCCACTGATGTTAGTCAGART ATCCATTC

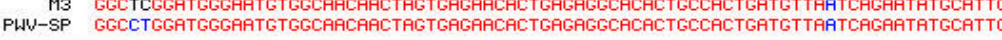

2 CCTCTTGGGGATGACGCATGGGCAO

191 CCTCTTGGGGATGACGCATGGGCAI

$\begin{aligned} \text { M3 } & \text { CCTCTTGGGGGATGACGCATGGGCAG } \\ \text { PWU-SP } & \text { CCTCTTGGGGATGACGCATGGGCAG }\end{aligned}$

Figura 14 - Alinhamento das seqüências de nucleotídeos do gene da capa protéica dos isolados M2 e M3 do potyvírus causador de mosqueado em maracujazeiro e de duas estirpes do PWV (PWV F-101 e PWV-SP) 


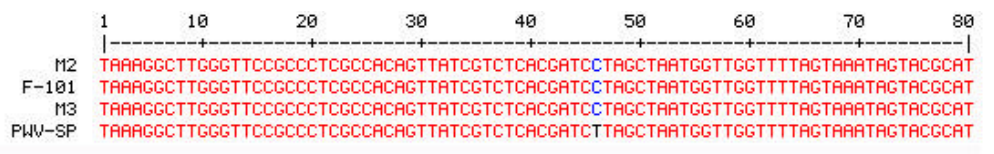

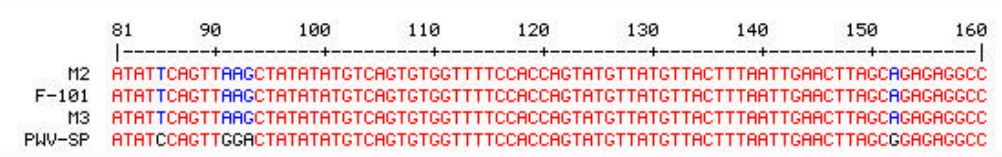

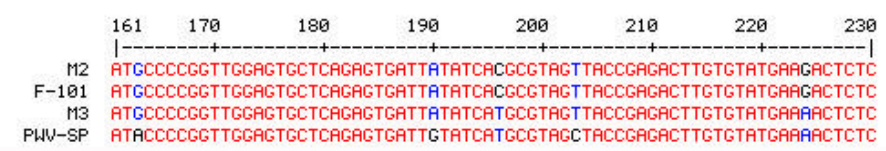

Figura 15 - Alinhamento das seqüências de nucleotídeos da região 3' não traduzida dos isolados M2 e M3 do potyvírus causador de mosqueado em maracujazeiro e de duas estirpes do PWV (PWV F-101 e PWV-SP)

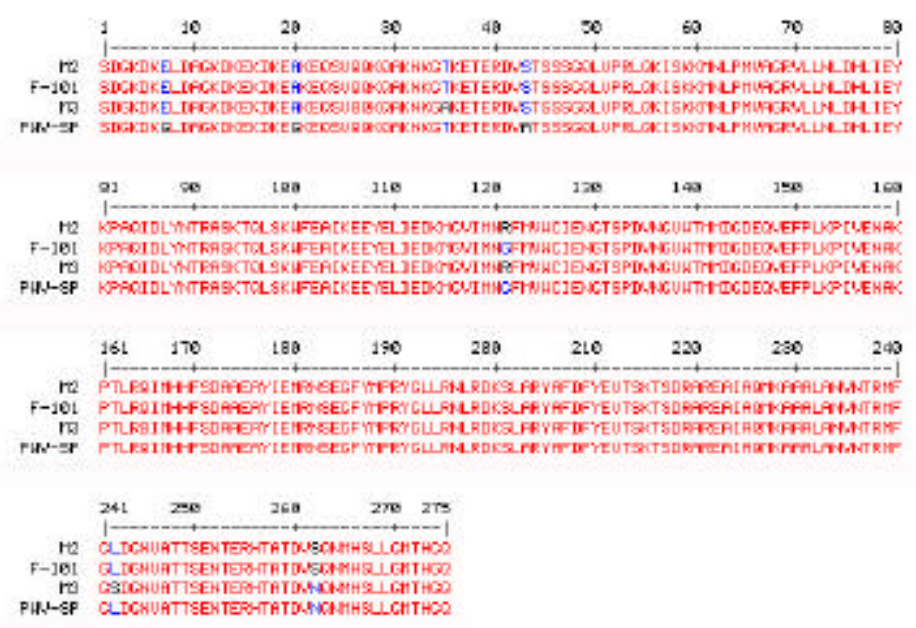

Figura 16 - Alinhamento das seqüências de aminoácidos deduzidos do gene da capa protéica dos isolados M2 e M3 do potyvírus causador de mosqueado em maracujazeiro e de duas estirpes do PWV (PWV F101 e PWV-SP) 
não traduzida e de aminoácidos deduzidos do gene da proteína da capa protéica, respectivamente, dos isolados M2 e M3 com os das seqüências dos dois potyvírus que apresentaram as maiores identidades, o PWV F-101 e PWVSP, oriundas do trabalho de Novaes (2002).

Observou-se maior identidade entre os isolados M2, M3, PWV F-101 e PWV-SP com o CABMV do que com os isolados do PWV oriundos da Austrália (PWV-A), Japão (PWV-J) e Taiwan (PWV-T). Quando comparados entre si, os isolados M2 e M3 apresentaram identidade de $98 \%$ e $99 \%$ no gene da capa protéica e na região não traduzida do terminal 3', respectivamente. Quando o isolado M2 foi comparado a estirpe PWV F-101, identidade de 99\% foi observada para o gene da capa protéica e de 100\% para o terminal 3' não traduzido. A mesma comparação efetuada com o isolado $M 3$ revelou identidade de $98 \%$ e 99\% para as mesmas regiões genômicas, respectivamente. Identidade de $97 \%$ foi observada tanto para o isolado M2 quanto para o M3 ao se comparar o gene da capa protéica dos mesmos com o da estirpe PWV-SP. Com relação à região terminal 3' não traduzida o isolado PWV-SP apresentou identidade de $95 \%$ e $96 \%$ com os isolados M2 e M3, respectivamente. Com relação à seqüência de aminoácidos deduzidos do gene da proteína da capa protéica dos isolados M2 e M3 e das duas estirpes do PWV foi observada identidade de $98 \%$ entre os dois isolados do potyvírus causador de mosqueado e de $97 \%$ quando os mesmos foram comparados com os isolados PWV F-101 e PWV-SP.

Quando os isolados M2 e M3 do potyvírus do mosqueado do maracujazeiro e os isolados PWV F-101 e PWV-SP foram comparados com o CABMV, constatou-se que a identidade da seqüência de nucleotídeos do gene da capa protéica variou de $86 \%$ a $87 \%$. Para a seqüência do terminal 3' não traduzido a identidade foi de $91 \%$ a $94 \%$, enquanto as seqüências de aminoácidos deduzidos da proteína da capa protéica apresentaram identidade de $90 \%$. A alta identidade entre os isolados M2, M3, PWV F-101 e PWV-SP 
com o CABMV também pode ser visualizada no dendrograma (Figura 13), onde eles se encontram agrupados.

Quando os isolados M2 e M3 do potyvírus do mosqueado do maracujazeiro foram comparados com os demais potyvírus, as identidades das seqüências de nucleotídeos do gene da capa protéica e da região 3' não traduzida variaram de $58 \%$ a $75 \%$ e $8 \%$ a $36 \%$, respectivamente. 


\section{DISCUSSÃO}

Nas observações, em microscopia eletrônica de transmissão, do purificado viral, obtido de plantas de maracujazeiro amarelo, e de cortes ultrafinos de tecidos de abobrinha-de-moita 'Caserta' e maracujazeiros foi possível constatar, respectivamente, a presença de partículas do tipo flexuosa, com dimensões de 670 - $750 \mathrm{~nm}$ de comprimento por 12 - $15 \mathrm{~nm}$ de diâmetro (Figura 6) e inclusões citoplasmáticas lamelares na configuração de cata-vento típicas do gênero Potyvirus (Figura 5) (Taylor \& Greber, 1973; Van Regenmortel et al., 2000).

Análises moleculares da partícula viral indicaram que a proteína da capa protéica tem peso molecular próximo a $32 \mathrm{kDa}$, (Figura 7) enquanto 0 RNA possui aproximadamente 10.000 pb (Figura 8), ambos semelhantes àqueles relatados para o gênero Potyvirus, da família Potyviridae (Van Regenmortel et al., 2000).

Como era de se esperar os testes de transmissão por afídeos mostraram que as espécies Myzus persicae e Aphis gossypii transmitiram de maneira eficiente esse Potyvirus.

Ao se avaliar a gama de hospedeiras do potyvírus causador de mosqueado em maracujazeiro, comparando-a com a dos dois isolados do PWV, único potyvírus até então relatado em maracujazeiro no Brasil, observou-se que das espécies infectadas pelos isolados do primeiro potyvírus, duas eram distintas daquelas observadas como hospedeiras do PWV, Cucurbita pepo cv. Caserta e abóbora híbrida 'Tetsukabuto' (C. máximaX C. moschata) (Tabela 2). Após a avaliação visual de sintomas nestas duas espécies houve a comprovação de infecção por testes serológicos. Por outro lado quando plantas 
sadias de 'Caserta' foram inoculadas com os isolados do PWV, observou-se pontuações cloróticas e posteriormente ocorreu remissão de sintomas. No caso de abóbora híbrida 'Tetsukabuto' não foram observados sintomas após a inoculação com os mesmos isolados. A detecção do PWV, em testes serológicos, nestes casos não foi possível. A transmissão experimental, de um aparente potyvírus, causador de manchas anelares em maracujazeiro, para plantas de C. pepo já foi relatada por Wijs (1974). As plantas se mostravam assintomáticas, porém o vírus foi recuperado das folhas inoculadas. Neste caso, o vírus causador de manchas anelares não foi identificado como estirpe do PWV, embora tenha apresentado relacionamento serológico com este. Estudos subseqüentes demonstraram tratar-se de uma estirpe do Potato vírus $Y$ (PVY). Em Taiwan, Chang (1992) caracterizou um potyvirus induzindo sintomas semelhantes aos do causador de mosqueado em maracujazeiro em São Paulo, denominando-o Passion fruit mottle virus (PFMoV). Este potyvírus, entretanto, não induziu sintomas em nenhuma das cucurbitáceas inoculadas.

$\mathrm{Na}$ avaliação do relacionamento serológico do potyvírus causador de mosqueado em maracujazeiro em São Paulo com outros potyvirus (Tabela 6) foram visados, além do PWV, dois potyvirus de importância em cucurbitáceas, o Papaya ringspot vírus - type watermelon (PRSV-W) e o Zucchini yellow mosaic virus (ZYMV), em função dos resultados obtidos nos testes para determinação do círculo de hospedeiros. O resultado obtido demonstrou que o vírus causador de mosqueado em maracujazeiro foi serologicamente relacionado somente com o PWV.

Para determinar se o potyvírus causador de mosqueado era ou não uma espécie distinta do PWV foram empregados o teste de proteção entre isolados desse potyvirus e do PWV (Tabela 7) e a comparação molecular do gene da capa protéica e da região 3' não traduzida (Tabela 10 e 11, Figura 13, 14, 15 e 16). A proteção é um dos requisitos para a identificação de estirpes de uma mesma espécie dentro da família Potyviridae (Van Regenmortel et al., 2000). Associada a proteção, a identidade entre as seqüências de nucleotídeos 
do gene da capa protéica e da região 3' não traduzida, são outros parâmetros de grande valor para a identificação de espécies da família Potyviridae (Van Regenmortel et al., 2000).

Nos experimentos de proteção com maracujazeiro e plantas de crotalária (Tabela 7) observou-se que os isolados PWV-1 e PWV-2 não protegeram plantas de maracujazeiro contra a infecção com os isolados M1, M2 e M3 do potyvírus do mosqueado. Apesar dessa ausência de proteção, houve um retardamento na infecção, visto que plantas sadias inoculadas com os isolados do potyvírus do mosqueado mostraram sintomas 10 dias após a inoculação, enquanto a recuperação dos mesmos isolados, quando inoculados em plantas previamente infectadas com os isolados do PWV, só foi possível, em 32 das 42 plantas testadas, aos 21 dias após o desafio. No caso das plantas de crotalária, os isolados do PWV ofereceram completa proteção contra os isolados M1, M2 e M3 do potyvírus do mosqueado do maracujazeiro. Esses resultados, além de evidenciarem o parentesco dos isolados do potyvírus do mosqueado com os do PWV de São Paulo, corroboram relato de Novaes (2002), sobre o efeito da espécie vegetal na proteção entre estirpes do PWV.

A comparação das seqüências de nucleotídeos do gene da capa protéica e da região terminal 3' não traduzida dos isolados do potyvírus do mosqueado do maracujazeiro com as de outros potyvírus (Tabela 10 e 11; Figura 13) consolidaram a suspeita de que aquele potyvírus é uma estirpe do PWV de São Paulo. Observou-se identidade superior a mínima necessária, segundo Van Regenmortel et al. (2000), 85\% para o gene da capa protéica e 75\% para a região 3' não traduzida, para agrupar os isolados M2 e M3, e os isolados do PWV (PWV F-101 e PWV-SP) como estirpes de um mesmo vírus. Análises adicionais revelaram que os isolados M2, M3, PWV F-101 e PWV-SP tem alta identidade com o CABMV, corroborando as observações efetuadas por Braz et al. (1998) e Santana et al. (1999) de que o vírus descrito no Brasil como PWV parece ser na verdade uma estirpe do CABMV. Fato semelhante foi constatado na África do Sul, onde um potyvírus encontrado em maracujazeiro e 
designado South african passiflora virus, foi posteriormente caracterizado como estirpe do CABMV (Brand et al., 1993; Van Regenmortel et al., 2000).

Com base nesses mesmos parâmetros, foi possível observar também que, aparentemente, há 3 grupos de potyvírus distintos que são designados por PWV mas que, na verdade, não parecem pertencer a mesma espécie de vírus (Tabela 10 e 11). Uma primeira espécie seria o PWV australiano. A segunda englobaria os isolados de Taiwan e do Japão, enquanto a terceira abrangeria os isolados brasileiros do PWV e o CABMV. Observa-se na Tabela 10 que a identidade entre os isolados brasileiros, australiano e Taiwan/japonês são inferiores a 75\%, o que apóia a sugestão de tratarem-se de espécies distintas. Estudos mais detalhados são recomendados no intuito de se esclarecer à classificação taxonômica do PWV não só no Brasil, mas também em caráter mundial.

Paralelamente aos experimentos para se determinar à relação de parentesco entre o potyvirus causador de mosqueado e o PWV, também foram efetuados alguns testes biológicos para a determinação da eficiência de transmissão mecânica e por afídeos do potyvírus do mosqueado, além da determinação de danos causados por isolados deste potyvírus em plantas de maracujazeiro em casa-de-vegetação, em comparação ao PWV.

Com relação àtransmissão mecânica (Tabela 3) e por afídeos (Tabela 4) foi observado que em ambos os casos, a eficiência de transmissão foi alta quando se empregou maracujazeiro amarelo, feijão preto cv. BT-2 e Crotalaria juncea como fontes de inóculo para inoculação mecânica ou aquisição do vírus pelos afídeos. Nestes casos, obteve-se alta porcentagem de transmissão do vírus, independentemente da forma de transmissão e da planta teste inoculada. O mesmo não ocorreu ao se empregar abobrinha-de-moita 'Caserta' como fonte de inóculo para a inoculação mecânica e para aquisição pelos afídeos. Nestes casos foi possível a transmissão apenas de 'Caserta' para 'Caserta', não sendo constatada a transmissão para as outras plantas-teste empregadas. Observout se também, em relação à'Caserta', que as folhas em início de desenvolvimento 
foram as melhores fontes para aquisição do potyvírus do mosqueado pelos afídeos M. persicae e A. gossypii (Tabela 5), porém, como já mencionado, após a aquisição pelos vetores a transmissão ocorreu somente para plantas sadias de 'Caserta'.

O efeito da fonte de inóculo na eficiência de transmissão de vírus por vetores não é fato novo, embora não parece ser comum com vírus de relação não persistente com o vetor. Foi relatado, principalmente para vírus com relação vírus/ vetor do tipo circulativa ou propagativa, que determinadas plantas acarretam dificuldades na aquisição do vírus pelo vetor, ou ainda reduzem a gama de hospedeiras do vírus após a aquisição. Na Índia, foi verificado por Pruthi \& Samuel (1939), que o vírus do encarquilhamento da folha do fumo pôde ser adquirido facilmente pelo vetor, Bemisia tabaciGenn., de hospedeiras da vegetação espontânea, $C$. juncea e Aegeratum conyzoides, e infectar facilmente o fumo. A aquisição em fumo foi mais difícil, sendo a transmissão de fumo para fumo rara, bem como de fumo para $C$. juncea. De fumo para $A$. conyzoides a transmissão foi mais fácil. $O$ vírus do broto crespo do tomateiro pôde ser facilmente transmitido para essa planta quando o vetor, Agallia albicula, adquiriu o vírus de Acanthospermum hispidum, mas não quando a aquisição foi feita em tomateiro (Costa, 1952).

A região na planta para aquisição do vírus pelo vetor também pode exercer grande influência na posterior eficiência de transmissão. Em folhas de fumo maduras, exibindo sintomas de infecção pelo PVY, que é transmitido de maneira não persistente por diferentes espécies de afídeos, os terços superiores próximos ì pontas foram melhores fontes para aquisição do vírus por M. persicae do que os dois terços próximos àbase. As áreas internervais também foram melhores para aquisição do que as nervuras (Bradley, 1962).

A concentração de vírus na planta tem grande importância na aquisição do vírus pelo vetor. Baixas concentrações virais nos tecidos de plantas infectadas podem estar diretamente associadas a decréscimos na 
aquisição e posterior eficiência de transmissão do vírus pelo vetor (Bradley, 1962).

Uma menor concentração do potyvírus do mosqueado do maracujazeiro em tecidos de abobrinha-de-moita cv. Caserta, além de poder explicar a baixa eficiência na transmissão por afídeos, poderia também justificar a baixa eficiência na transmissão mecânica de 'Caserta' para maracujazeiro, crotalária e feijoeiro BT-2. A não transmissão para essas espécies pode ter ocorrido em função da concentração viral presente no inóculo ser inferior à necessária para causar infecção nas espécies vegetais testadas. A transmissão mecânica observada de 'Caserta' para 'Caserta' pode estar associada a maior sensibilidade das mesmas àtransmissão/ infecção, ou seja, concentrações virais relativamente baixas são capazes de ocasionar a infecção desta abobrinha-de-moita.

O decréscimo ou mesmo perda na transmissibilidade de potyvírus de relação não persistente com os afídeos vetores também pode estar associada com mutações que acontecem na capa protéica ou na proteína auxiliar de transmissão, denominada "Helper component protease" (HCPro) (Pirone, 1991). Alterações de lisina para ácido glutâmico em posição equivalente foi associada com a perda de atividade da HCPro de isolados do ZYMV e do PVY-1 com conseqüente inviabilização na transmissão destes vírus por afídeos vetores (Pirone \& Blanc, 1996).

Podem ser vislumbrados alguns procedimentos na tentativa de elucidar o problema ocorrido na transmissão do potyvírus causador de mosqueado em maracujazeiro, como por exemplo: estimar a concentração viral nos tecidos de abobrinha-de-moita 'Caserta' e compará-la com a concentração encontrada nos tecidos das outras espécies vegetais; promover inoculações das plantas-teste com concentrações decrescentes do vírus do mosqueado purificado; seqüênciar o gene da capa protéica e da HCPro de isolados do vírus do mosqueado após infecção em 'Caserta' e compará-las com àquelas obtidas dos mesmos isolados quando infectando maracujazeiros. 
Apesar da procura por explicações para o fato acima citado não ter sido objeto deste trabalho, importante informação prática pode ser tirada. A abobrinha-de-moita 'Caserta', apesar de ser infectada por este potyvírus causador de mosqueado em maracujazeiro, não parece contribuir como fonte de inóculo do vírus para a infecção de maracujazeiros em campo, o mesmo não sendo verdadeiro para feijão preto cv. BT-2 e $C$. juncea. O maracujazeiro, por outro lado, poderia ser fonte deste vírus para 'Caserta' e 'Tetsukabuto', havendo a necessidade da avaliação de potenciais danos que poderiam ser ocasionados por este potyvírus na cultura destas cucurbitáceas.

Com relação aos experimentos para avaliação de possíveis danos dos isolados do potyvírus do mosqueado sob condições de casa-de-vegetação e comparação com o PWV (Figura 10 e 11; Tabela 8 e 9), não foram observados prejuízos significativos como os ocasionados pelo PWV, que poderiam refletir na produção futura. Enquanto para os isolados do PWV observaram-se sempre danos superiores a $50 \%$, para as variáveis peso fresco e seco do sistema radicular e parte aérea, índice de área foliar e altura das plantas, para os isolados do potyvírus do mosqueado os danos sempre foram inferiores a $45 \%$. Para os isolados M1 e M2 não foram observados danos que pudessem diferenciá-los estatisticamente das testemunhas. Os resultados de danos associados ao PWV em plantas de maracujazeiro em estádio inicial de desenvolvimento foram semelhantes aos relatados por Gioria et al. (2000).

Diferenças sintomatológicas entre estirpes do PWV já foram relatadas na Austrália e no Brasil. Greber (1966) relatou a presença de uma estirpe do PWV (PWV-TB) associada a grandes danos na região Central de QueensInad (Austrália). Plantas infectadas apresentavam epinastia, clareamento de nervuras e necrose no ponteiro. Shukla et. al (1988) após seqüenciamento da proteína da capa protéica deste isolado, confirmaram tratar-se de uma estirpe com $85-86 \%$ de identidade com a estirpe de maior ocorrência na Austrália (PWV-S), que induzia sintomas de mosaico, formação de bolhas, deformação e diminuição de limbo foliar. Gough \& Shukla (1992), após seqüenciamento da 
região 3' não traduzida e da capa protéica, confirmaram a existência de três estirpes do PWV que já estavam relatadas na Austrália e que eram diferenciadas justamente pela sintomatologia. A PWV-TB relatada por Greber (1966), a PWV-S cujos sintomas já foram descritos acima, e a PWV-M, uma estirpe fraca que induzia sintomas quase imperceptíveis de mosaico e cuja principal utilização data dos trabalhos de Simmonds (1959), na qual foi empregada na premunização de maracujazeiros. No Brasil, isolados do PWV que induziram sintomas quase imperceptíveis foram obtidos de plantas de maracujazeiro selecionadas em plantios no município de Vera Cruz (SP). Tentativas de utilização desses isolados para a premunização de maracujazeiros falharam (Novaes, 2002). 


\section{CONCLUSÕES}

1- O potyvírus causador de mosqueado em maracujazeiro é uma estirpe do Passion fruit woodiness virus (PWV) que ocorre no Estado de São Paulo.

2- O potyvírus do mosqueado do maracujazeiro é uma estirpe do Cowpea aphid-borne mosaic virus (CABMV). 


\section{REFERÊNCIAS BIBLIOGRÁFICAS}

BATISTA, F.A.S.; GOMES, R.C.; RAMOS, V.F. Ocorrência de uma anormalidade de possível causa virótica ou semelhante a vírus, provocando "enfesamento" do maracujazeiro. In: CONGRESSO BRASILEIRO DE FRUTICULTURA, 6., Recife, 1981. Anais. Recife: SBF, 1981. p.1408-1413.

BENSCHER, D.; PAPPU, S.S.; NIBLETT, C.L.; AGUDELO, F.V.; MORALES, F.; HODSON, E.; ALVAREZ, E.; ACOSTA, O.; LEE, R.F. A strain of Soybean mosaic virus infecting Passiflora spp. In Colômbia. Plant Disease, v.80, p.258-262, 1996.

BERGER, P.H.; SHIEL, P.J. Potyvirus isolation and RNA extraction. In: FOSTER, G.D.; TAYLOR, S.C. Plant virology protocols. New Jersey: Humana Press, 1998. p.151-160.

BEZERRA, D.R.; LIMA, J.A.A.; XAVIER FILHO, J. Purificação e caracterização de um isolado cearense do vírus do endurecimento dos frutos do maracujazeiro. Fitopatologia Brasileira, v.20, p.553-560, 1995.

BRADLEY, R.H.E. Response of the aphid Myzus persicae (Sulz.) to some fluids applied to the mouthparts. Cannadian Entomology, v.94, p.707-722, 1962. 
BRAND, R.J.; BURGER, J.T.; RYBICKI, E.P. Cloning, sequencing, and expression in Escherichia coli of the coat protein gene of a new potyvirus infection South African Passiflora. Archives of Virology, v.128, p.29-41, 1993.

BRAZ, A.S.K.; SANTANA, E.N.; MACIEL-ZAMBOLIM, E.; OTONI, W.C.; COSTA, A.F.; ZERBINI, F.M. Molecular characterization of two isolates of South African passiflora potyvirus in Brazil. Fitopatologia Brasileira, v.23, p.313, 1998.

CEREDA, E.; FERREIRA, G. Sistema de condução e manejo da cultura do maracujazeiro. In: RUGGIERO, C. (Ed.). Maracujá do plantio à colheita. Jaboticabal: FUNEP, 1998. p.93-103.

CHAGAS, C.M. Doenças viróticas e similares do maracujazeiro no Brasil. In: SÃO JOSÉ, A.R. (Ed.) A cultura do maracujazeiro no Brasil. Jaboticabal: FUNEP, 1991. 175-186.

CHAGAS, C.M.; JOAZEIRO, P.P.; KUDAMATSU, M.; VEJA, J. Mosaico do maracujá roxo, uma nova virose no Brasil. Fitopatologia Brasileira, v.9, p.241-247, 1984.

CHAGAS, C.M.; KITAJIMA, E.W.; LIN, M.T.; GAMA, M.I.C.S.; YAMASHIRO, T. Grave moléstia em maracujá amarelo (Passiflora edulis f. flavicarpa Deg.) no Estado da Bahia, causada por um isolado do vírus do "woodiness" do maracujá. Fitopatologia Brasileira, v.6, p.259-268, 1981. 
CHAGAS, C.M.; REZENDE, J.A.M.; COLARICCIO, A.; PIZA Jr., C.T.; LOPES, L.C.; GALLETTI, S.R.; PERRARI, J.T.; BELLUZ. B.M. Ocorrência do endurecimento do fruto do maracujazeiro (VEFM) no Estado de São Paulo. Revista Brasileira de Fruticultura, v.14, p.187-190, 1992.

CHANG, C.A. Characterization and comparison of Passion fruit mottle virus, a newly recognized potyvirus, with Passion fruit woodiness virus. Phytopathology, v.82, n.12, p.1358-1363, 1992.

CHEN, M.C. The nucleotide sequence of the 3'- terminal region of passion fruit woodiness virus. Taichung, 1992. 520p. Thesis (Master)- National Chung Hsing University.

COLARICCIO, A.; CHAGAS, C.M.; MIZUKI, M.K.; VEGA, J.; CEREDA, E. Infecção natural do maracujá amarelo pelo vírus do mosaico do pepino no Estado de São Paulo. Fitopatologia Brasileira, v.12, p.254-257, 1987.

CONCl, V.L. Técnicas serológicas. In: DOCAMPO, D.M.; LENARDÓN, S.L. (Ed.). Métodos para detectar patógenos sistêmicos. Córdoba: IFFIVE; INTA; JICA, 1999. cap.2, p.23-39.

COSTA, A.F. Contribuição ao estudo da epidemiologia e controle do vírus do endurecimento dos frutos do maracujazeiro. In: CONGRESSO DA SOCIEDADE BRASILEIRA DE FITOPATOLOGIA, 18., Fortaleza, 1985. Resumos. Fitopatologia Brasileira, v.10, n.2, p.310, 1985.

COSTA, A.F.; BRÁS, A.S.K.; CARVALHO, M.G. Transmissão do vírus do endurecimento dos frutos de maracujazeiro (VEFM) por afídeos (HemipteraAphididae). Fitopatologia Brasileira, v.20, p.376, 1995. Suplemento 
COSTA, A.S. Further studies on tomato curly top in Brazil. Phytopathology, v.42, p.396-403, 1952.

CRESTANI, O.A.; KITAJIMA, E.W.; LIN, M.T.; MARINHO, V.L.A. Passion fruit yellow mosaic vírus, a new tymovirus found in Brazil. Phytopathology, v.76, p.951-955, 1986.

CRESTANI, O.A.; KITAJIMA, E.W.; LIN, M.T.; MARINHO, V.L.A.; PIMENTEL, J.P. Uma nova virose em maracujazeiro - mosaico amarelo - causada por um tymovirus. In: CONGRESSO DA SOCIEDADE BRASILEIRA DE FITOPATOLOGIA, 17., São Paulo, 1984. Resumos. Fitopatologia Brasileira, v.9, p.394, 1984.

FNP CONSULTORIA \& COMÉRCIO. Agrianual 1998: anuário da agricultura brasileira. São Paulo, 1998. 481p.

FNP CONSULTORIA \& COMÉRCIO. Agrianual 1999: anuário da agricultura brasileira. São Paulo, 1999. 521p.

FNP CONSULTORIA \& COMÉRCIO. Agrianual 2002: anuário da agricultura brasileira. São Paulo, 2002. 536p.

FRIBOURG, C.E.; KOENING, R.; LESEMANN, D.E. A new tobamovirus from Passiflora eduli in Peru. Phytopathology, v.77, n.3, p.486-491, 1987.

GIBBS, A.; MACKENZIE, A. A primer pair for amplifying part of the genome of all potyvirids by RT-PCR. Journal of Virological Methods, v.63, p.9-16, 1997. 
GIORIA, R.; REZENDE, J.A.M. Reação de diferentes espécies, principalmente de leguminosas, a seis isolados do Vírus do Endurecimento dos Frutos do Maracujazeiro. In: SIMPÓSIO DE INICIAÇÃO CIENTíFICA DA UNIVERSIDADE DE SÃO PAULO, 4., Piracicaba, 1996. Resumo. São Paulo: USP, 1996. p.437.

GIORIA, R., BOSQUÊ, G.G., REZENDE, J.A.M., AMORIM, L.; KITAJIMA, E.W. Incidência de viroses de maracujazeiro na Alta Paulista - SP e danos causados pelo "Passion fruit woodiness virus". Fitopatologia Brasileira, v.25, n.2, p.182-189, 2000.

GIORIA, R.; ESPINHA, L.M.; REZENDE, J.A.M.; GASPAR, J.O.; KITAJIMA, E.W. Limited moviment of Cucumber mosaicv virus (CMV) in yellow passion flower in Brazil. Plant Pathology, v.51, p.127-133, 2002.

GOMES, F.D. Curso de estatística experimental. 13.ed. Piracicaba: Nobel, 1990. 468p.

GOUGH, K.H.; SHUKLA, D.D. Major sequence variations in the $\mathrm{N}$-terminal region of the capsid protein of a severe strain of passionfruit woodiness potyvirus. Archives of Virology, v.124, p.389-396, 1992.

GREBER, R.S. Passion-fruit woodiness vírus as the cause of passion vine tip blight disease. Queensland Journal of Agricultural and Animal Sciences, v.23, p.533-538, 1966.

HOEHNE, F.C. Frutas indígenas. São Paulo: Instituto de Botânica, 1946. 96p. 
HOISINGTON, D.; KAIRHALLAH, M.; GONZALEZ-DE LEON, D. Laboratory protocols. 2.ed. Mexico: CIMMYT, Applied Molecular Genetics Laboratory, 1994. 51p.

INOWE, A.K.; MELLO, R.N.; NAGATA, T.; KITAJIMA, E.W. Characterization of passion fruit woodiness isolates from Brasília and surrouding region, Brasil. Fitopatologia Brasileira, v.20, n.3, p.479-487, 1995.

KITAJIMA, E.W.; NOME, C.F. Microscopia electronica em virologia vegetal. In: DO CAMPO, D.M.; LENARDÓN, S.L. (Ed.). Métodos para detectar patógenos sistêmicos. Córdoba: IFFIVE; INTA; JICA, 1999. cap.3., p.5987.

KITAJIMA, E.W.; CHAGAS, C.M.; CRESTANI, O.A. Enfermidades de etiologia viral e associadas a organismos do tipo micoplasma em maracujazeiro no Brasil. Fitopatologia Brasileira, v.11, p.409-432, 1986.

KITAJIMA, E.W.; REZENDE, J.A.M.; RODRIGUES, J.C.V.; CHIAVEGATO, L.G.; PIZA Jr., C.T.; MOROZINI, W. Green spot of passion fruit, a possible viral disease associated with infestation by the mite Brevipalpus phoenicis. Fitopatologia Brasileira, v.22, p.555-559, 1997.

KOENING, R.; FRIBOURG, C.E. Natural occurence of tomato ringspot vírus in Passiflora edulis from Peru. Plant Disease, v.70, n.3, p.244-245, 1986.

LIMA, J.A.A.; OLIVEIRA, V.B.; FILHO, J.T. Avaliação dos graus de incidência de vírus em pomares de maracujazeiro, na Serra de Ibiapaba, Ceará. Caatinga, v.9, p.61-66, 1996. 
LORETO, T.J.G.; VITAL, A. Viroses e micoplasmoses do maracujá em Pernambuco. Cidade: SERDV, 1983. 23p.

MANIATIS, T.; FRISCH, E.F.; SAMBROOK,J. Molecular clonnig: a laboratory manual. 2.ed. New York: Cold Spring Harbor Laboratory Press, 1989 3v.

MARINHO, V.L.A.; KITAJIMA, E.W. Um método simplificado de purificação de potyvírus. Fitopatologia Brasileira, v.14, p.91-93, 1989.

MLOTSHWA, S.; VERNER, J.; SITHOLE-NIANG, I.; VAN KAMPEN, T.; VAN KAMMEN, A.; WELLINK, J. The genomic sequence of cowpea aphidborne mosaic virus and its similarities with other potyviruses. Archives of Virology, v.147, p.1043-1052, 2002.

MORAES, M.C.; VIEIRA, M.L.C.; NOVAES, Q.S.; REZENDE, J.A.M. susceptibilidade de Passiflora nítida ao Passion fruit woodiness vírus. Fitopatologia Brasileira, v.27, p.108, 2002.

MOWAT, W.P.; DAWSON, S. Detection of plant viruses by ELISA using crude sap extracts and unfractionated antisera. Journal of Virological Methods, v.15, p.233-247, 1987.

NOVAES, Q. S. Seleção de estirpes fracas do Passion fruit woodiness virus e tentativas de premunização para o controle do endurecimento dos frutos do maracujazeiro, Piracicaba, 2002. 74p. Tese (Doutorado) - Escola Superior de Agricultura "Luiz de Queiroz", Universidade de São Paulo.

NOVAES, Q.S.; MELETTI, L.M.M.; VIEIRA, M.L.C.; REZENDE, J.A.M. Seleção preliminar de maracujazeiro para tolerância ao Passion fruit woodiness virus. Fitopatologia Brasile ira, v.25, p.452, 2000. 
NOVAES, Q.S.; FREITAS-ASTUA, J.; SÃO JOSÉ, A.R.; YUKI, V.A.; KITAJIMA, E.W.; REZENDE, J.A.M. Infecção mista de maracujazeiro com o Passion fruit woodiness virus e um begomovírus no estado da Bahia. Fitopatologia Brasileira, v.27, p.648, 2002.

PARES, R.D.; MARTIN, A.B.; FITZELL, R.D. Virus-induced tip necrosis of passion fruit (Passiflora edulis Sims.). Australian Plant Pathology, v.14, p.76-78, 1985.

PARES, R.D.; GUNN, L.V.; KESKULA, E.N. MARTIN, A.B.; TEAKLE, D.S. Ocurrence of passiflora latent carlavirus on cultivated and wild Passiflora species in Australia. Plant Disease, v.81, n.4, p.348-350, 1997.

PEASLEY, D.; FITZELL, R. D. Passion fruit industry benefits through scion wood scheme. Agricultural Gazette of the New South Wales, v. 92, p. 5$8,1981$.

PIO-RIBEIRO, G.; MARIANO, R.L.R. Doenças do maracujazeiro (Passiflora spp). In: KIMATI, H.; AMORIM, L.; BERGAMIM FILHO, A.; CAMARGO, L.E.A.; REZENDE, J.A.M. (Ed.). Manual de fitopatologia. 3.ed. São Paulo: Agronômica Ceres, 1997. v.2: Doenças das plantas cultivadas, p.525-534.

PIRONE, T.P. Viral genes and gene products that determine insect transmissibility. Seminary of Virology, v.2, p.81-87, 1991.

PIRONE, T.P.; BLANC, S. Helper-dependent vector transmission of plant viruses. Annual Review of Phytopathology, v. 34, p. 227-247, 1996. 
PRUTHI, H.S.; SAMUEL, C.K. Entomological investigations on the leaf curl disease of tobacco in Northern India. III. The transmission of leaf curl by whitefly Bemisia gossypiperda to tobacco, sannhemp and a new alternative host of the curl virus. Indian Journal of Agricultural Science, v.9, p. 223275, 1939.

REZENDE, J.A.M. Doenças de vírus e micoplasma do maracujazeiro no Brasil. In: SÃO JOSÉ, A.R. (Ed.) Maracujá, produção e mercado. Vitória da Conquista: UESB, 1994. p. 116-125.

SAMBROOK, J.; MANIATIS, T.; FRISCH, E.F. Molecular clonning: a laboratory manual. 2.ed. New York: Cold Spring Harbor Laboratory Press, 1989. 3v.

SANTANA, E.N. Caracterização de isolados brasileiros de Potyvirus causador de endurecimento dos frutos do maracujazeiro e avaliação de plantas transgênicas de maracujá-amarelo expressando RNAs virais, Viçosa, 2001. 75p. Tese (Doutorado) - Universidade Federal de Viçosa.

SANTANA, E.N.; BRAZ, A.S.K.; TORRES, L.B.; MACIEL-ZAMBOLIM, E.; ZERBINI, F.M. Molecular characterization of Potyvirus isolates causing passion fruit woodiness in Brazil. Virus Reviews \& Research, v.4, p.153, 1999.

SÃO JOSÉ, A.R.; REZENDE, J.A.M.; COSTA, A.F. Ocorrência do vírus do endurecimento do fruto do maracujazeiro no Norte do Estado de Minas Gerais. In: CONGRESSO BRASILEIRO DE FRUTICULTURA, 13., Salvador, 1994. Anais. Salvador: SBF, 1994, p.797.

SAS INSTITUTE. SAS/STAT user's guide: release 6.08. ed. Cary, 1993. 
SHUKLA, D.D.; McKERN, N.M.; WARD, C.W. Symptomatology, serology and coat protein sequences of three strains of passionfruit woodiness virus. Archives of Virology, v.102, p.221-232, 1988.

SILVA, A.C.; SÃO JOSÉ, A.R. Classificação botânica do maracujazeiro. In: SÃO JOSÉ, A.R. (Ed.). Maracujá produção e mercado. Vitória da Conquista, UESB, 1994. p. $1-5$.

SIMMONDS, J.H. Mild strain protection as a means of reducing losses from the queensland woodiness vírus in the passion vine. Queensland Journal of Agricultural and Animal Sciences, v.16, p.371-380, 1959.

TAYLOR, R.H.; GREBER, R.S. Passion fruit woodiness virus. Local: CMI; AAB, 1973. 4p. (Description of Plant Viruses, 122).

TAYLOR, R.H.; KIMBLE, K.A. Two unrelated viruses which cause woodiness of passion fruit (Passiflora edulis Sims). Australian Journal of Agricultural Science, v.15, p.560-570, 1964.

TRINDADE, D.R.; POLTRONIERI, L.S.; ALBUQUERQUE, F.C.; REZENDE, J.AM.; NOVAES, Q.S.; KITAJIMA, E.W. Ocorrência do "Passion fruit woodiness vírus" (PWV) em maracujazais no Estado do Pará. Fitopatologia Brasile ira, v.24, n.1, p.76-79, 1999.

VAN REGENMORTEL, M.H.V.; FAUQUET, C.M.; BISHOP, D.H.L.; CARSTENS, E.B.; ESTES, M.K.; LEMON, S.M.; MANILOFF, J.; MAYO, M.A.; McGEOCH, D.J.; PRINGLE, C.R.; WICKNER, R.B. Virus taxonomy: seventh report of the international Committee on Taxonomy of Viruses. San Diego: Academc Press, 2000. 1162p. 
WIJS, J.J. A virus causing ringspot of Passiflora edulis in the Ivory Coast. Annals of Applied Biology, v.77, p.33-40, 1974.

YAMASHIRO, T.; CHAGAS, C.M. Ocorrência de grave virose em maracujá amarelo (Passiflora edulis f. flavicarpa Deg.), no Estado da Bahia. In: CONGRESSO BRASILEIRO DE FRUTICULTURA, 5., Pelotas, 1979, Anais. Pelotas: SBF, 1979. p.915-917. 